Recreation Management Support Program

\title{
Economic Impacts from Spending by Marina Slip Renters and Private Dock Owners at Lake Sidney Lanier
}

Dennis B. Propst, Wen-Huei Chang, Richard Kasul,

February 2008

LiChu Lee, and Kathleen Perales, and Benoni L. Amsden

US Army Corps

of Engineers ${ }_{\circledast}$

Engineer Research and

Development Center

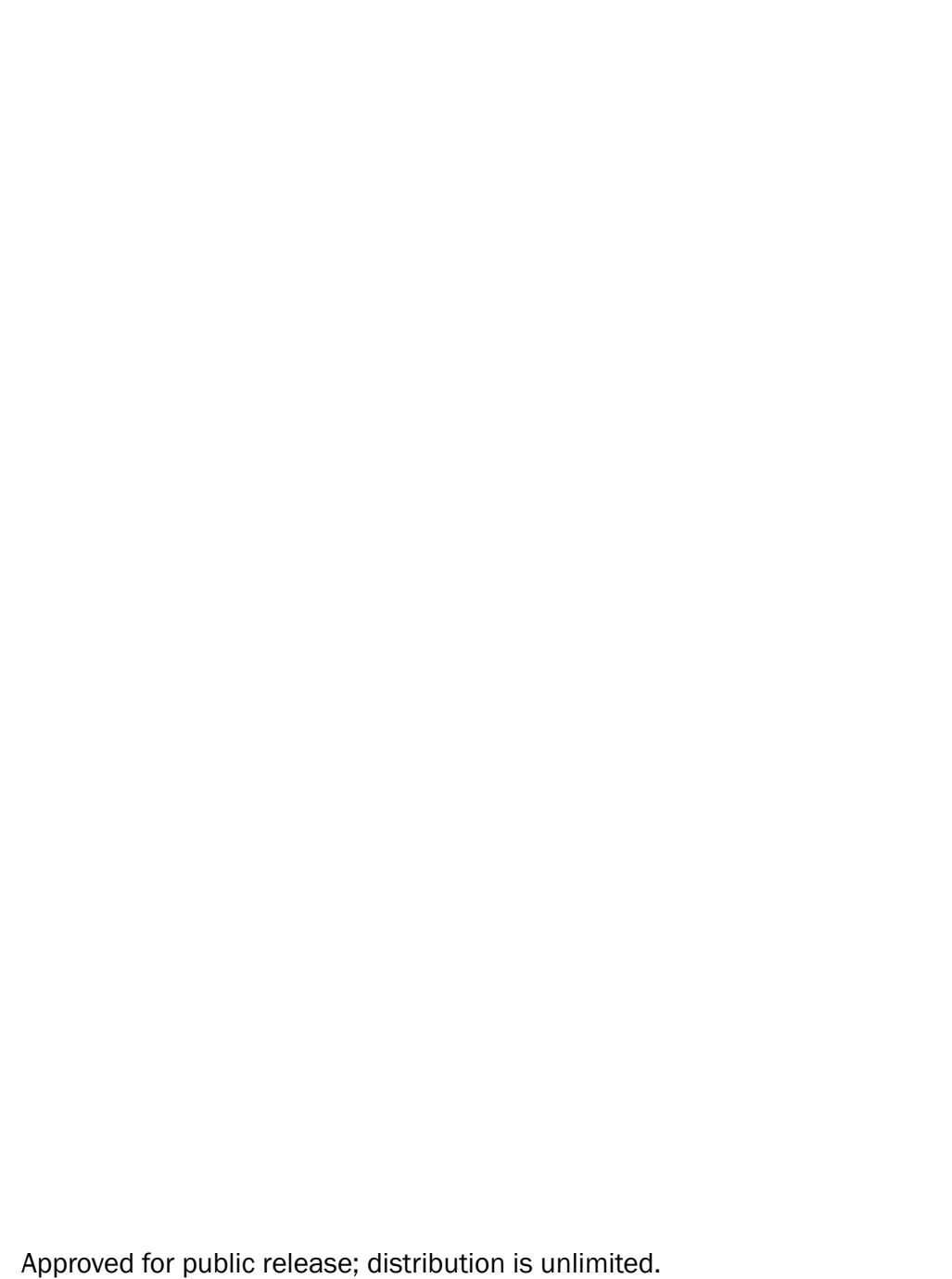




\section{Economic Impacts from Spending by Marina Slip Renters and Private Dock Owners at Lake Sidney Lanier}

Dennis B. Propst and Benoni L. Amsden

Michigan State University

115 Natural Resources Building

East Lansing, MI 48824

Wen-Huei Chang, Richard Kasul, LiChu Lee, and Kathleen Perales

Environmental Laboratory

U.S. Army Engineer Research and Development Center

3909 Halls Ferry Road

Vicksburg, MS 39180-6199

Final report

Approved for public release; distribution is unlimited.

Prepared for U.S. Army Corps of Engineers

Washington, DC 20314-1000 


\begin{abstract}
This report documents the local economic impacts of marina slip users and private dock users at Lake Sidney Lanier, located in northern Georgia. This economic assessment is based on the results of a 1999 survey of the samples of Lake Sidney Lanier marina slip renters and private dock owners. Spending estimates are adjusted to 2004 dollars. The economic impacts estimated for Lake Sidney Lanier are useful for accountability purposes, lake support, and explaining the role of the lake in the region's economy. This report demonstrates how the survey results can also be used to evaluate management alternatives and strategies and to conduct sensitivity analyses.
\end{abstract}

DISCLAIMER: The contents of this report are not to be used for advertising, publication, or promotional purposes. Citation of trade names does not constitute an official endorsement or approval of the use of such commercial products. All product names and trademarks cited are the property of their respective owners. The findings of this report are not to be construed as an official Department of the Army position unless so designated by other authorized documents. 


\section{Contents}

Figures and Tables.......................................................................................................................

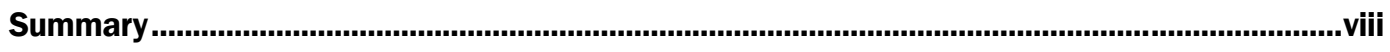

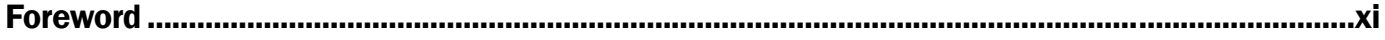

Preface ....................................................................................................................................... xii

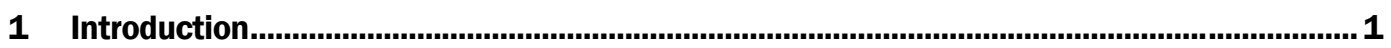

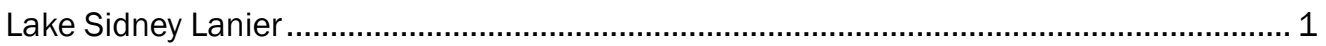

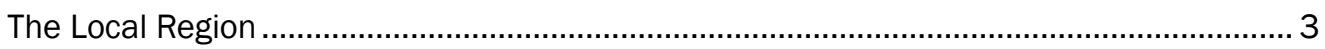

2 Marina Slip Renter and Private Dock Owner Survey, 1998-99 …......................................... 5

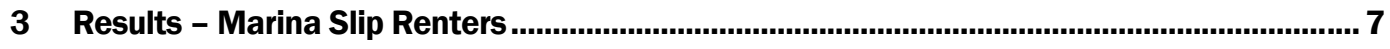

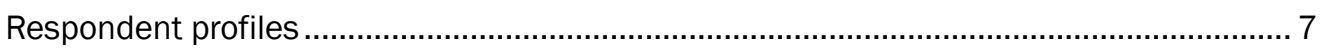

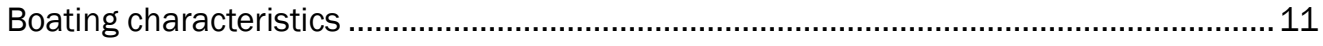

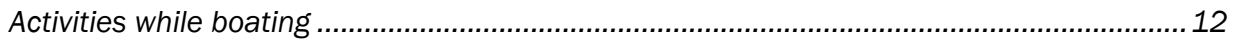

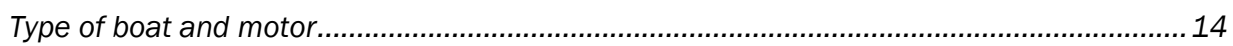

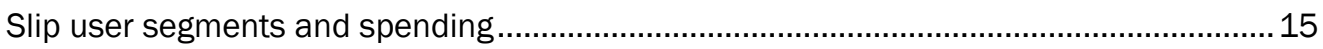

Average spending for full sample of slip renters........................................................ 15

Average spending by segment: Day use vs. overnight.................................................... 18

Average spending by boat length segments.................................................................... 19

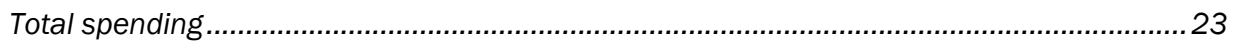

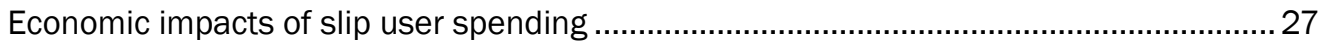

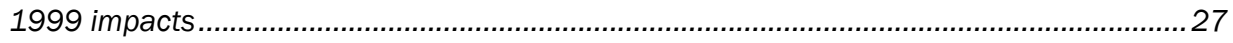

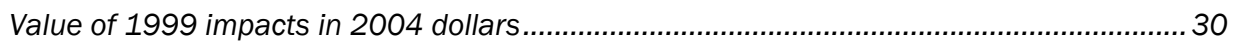

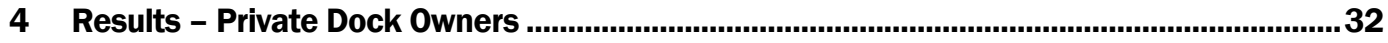

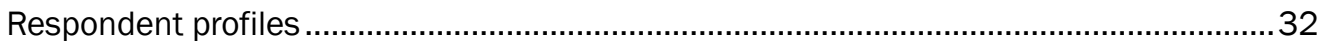

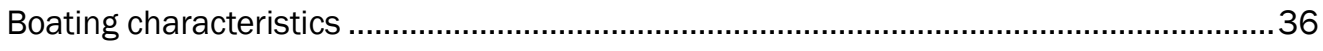

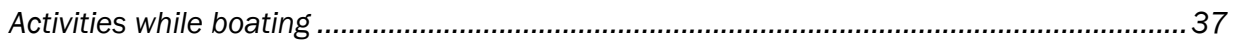

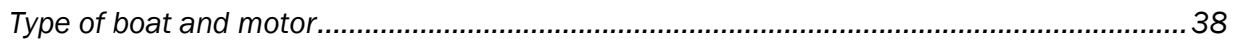

Dock user segments and spending............................................................................. 39

Average spending for full sample of dock owners .............................................................. 40

Average spending by segment: Day use vs. overnight........................................................ 43

Average spending by boat length segments.................................................................. 45

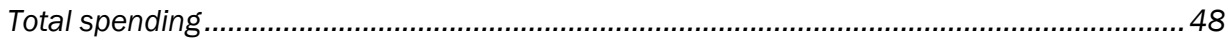

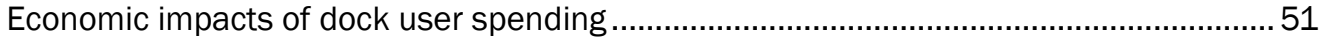

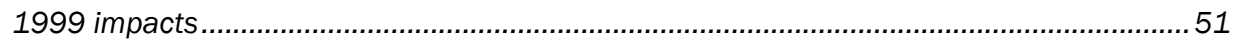

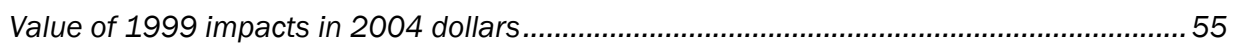

5 Comparison of Marina Slip Renters and Private Dock Owners ......................................56

Demographic profiles (Table 33) ...................................................................................... 56 


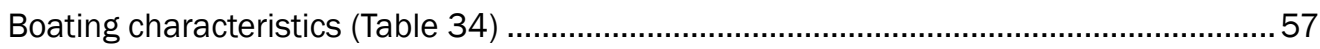

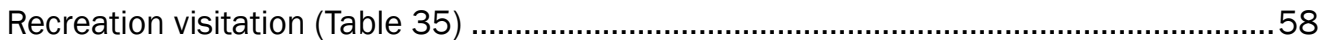

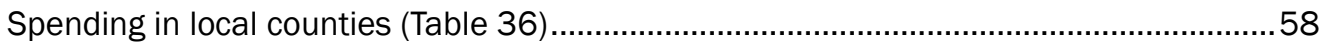

Trip characteristics (Table 37$)$........................................................................................... 59

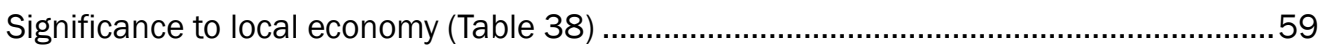

6 Study Limitations and Error...................................................................................................60

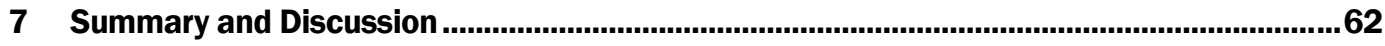

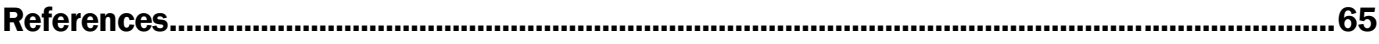

Report Documentation Page 


\section{Figures and Tables}

\section{Figures}

Figure 1. Lake Sidney Lanier and the surrounding region.

Figure 2. Gender of marina slip renters at Lake Sidney Lanier, 1999 ( $\mathrm{N}=210)$............................. 7

Figure 3. Age of marina slip renters at Lake Sidney Lanier, $1999(\mathrm{~N}=208)$.................................... 8

Figure 4. Education of marina slip renters at Lake Sidney Lanier, 1999 ( $\mathrm{N}=209)$.......................... 8

Figure 5. Race of marina slip renters at Lake Sidney Lanier, 1999 (N=199) (about 2 percent were Hispanic or of Latino origin) . ................................................................................. 8

Figure 6. Survey conducted with registered boat owners at Lake Sidney Lanier Marina,

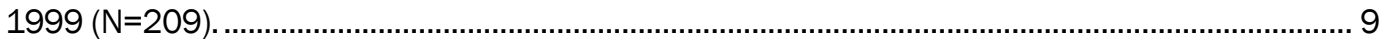

Figure 7. Household income of marina slip renters at Lake Sidney Lanier, 1999 (N=182)............. 9

Figure 8. Household size of marina slip renters at Lake Sidney Lanier, 1999 (N=209)................. 10

Figure 9. Number of people under 18 in households of marina slip renters at Lake Sidney Lanier, 1999 (N=208).......................................................................................................... 10

Figure 10. Permanent residence of marina slip renters at Lake Sidney Lanier, 1999 $(\mathrm{N}=211)$.

Figure 11. Seasonal home ownership of marina slip renters at Lake Sidney Lanier, 1999 $(\mathrm{N}=211)$.

Figure 12. Number of boating trips made by marina slip renters last year compared to previous 3-year average at Lake Sidney Lanier, 1999 (N=185).

Figure 13. "What other activities did you or others participate in during your boating trips last year that I have not already mentioned?" (from Lake Sidney Lanier Marina, 1999, $\mathrm{N}=203$ ).

Figure 14. Expenditures by marina slip renters/users on most recent trip compared to

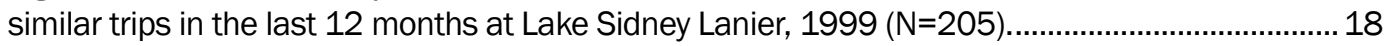

Figure 15. Gender of private dock owners at Lake Sidney Lanier, 1999 (N=338)..........................32

Figure 16. Age of private dock owners at Lake Sidney Lanier, 1999 ( $\mathrm{N=332})$..............................33

Figure 17. Education of private dock owners at Lake Sidney Lanier, $1999(\mathrm{~N}=330)$.......................33

Figure 18. Race of private dock owners at Lake Sidney Lanier, 1999 (N=332) (about 3 percent were Hispanic or of Latino origin).

Figure 19. Survey conducted with registered boat owners at Lake Sidney Lanier private docks, 1999 ( $\mathrm{N}=338)$.

Figure 20. Household income of private dock owners at Lake Sidney Lanier, 1999 $(\mathrm{N}=300)$

Figure 21. Household size of private dock owners at Lake Sidney Lanier, 1999 (N=337).

Figure 22. Number of people under 18 in households of private dock owners at Lake Sidney Lanier, 1999 ( $\mathrm{N}=337)$.

Figure 23. Permanent residence of private dock owners at Lake Sidney Lanier, 1999 $(\mathrm{N}=341)$.

Figure 24. Seasonal home ownership of private dock owners at Lake Sidney Lanier, 1999 ( $\mathrm{N}=341)$. 
Figure 25. Number of boating trips made by private dock owners last year compared to previous 3-year average at Lake Sidney Lanier, 1999 (N=307).

Figure 26. "What other activities did you or others participate in during your boating trips last year that I have not already mentioned?" (from Lake Sidney Lanier private docks, 1999, $\mathrm{N}=301)$.

Figure 27. Expenditures by private dock owners/users on most recent trip compared to similar trips in the last 12 months at Lake Sidney Lanier, 1999.(N=317)......

\section{Tables}

Table 1. Summary of recreation visits to Lake Sidney Lanier, 1999.............................................. 3

Table 2. Economic activity in the Lake Sidney Lanier region, 2000.................................................. 4

Table 3. Number of boating trips to Lake Sidney Lanier Marina the previous year (09/01/1998 to 08/31/1999).

Table 4. Recreation activity participation during previous year's boating trips to Lake Sidney Lanier Marina (09/01/1998 to 08/31/1999).

Table 5. Boat type and length cross-tabulation, Lake Sidney Lanier Marina slip renter survey, 1999 ( $\mathrm{N}=210)$.

Table 6. Boat type and motor cross-tabulation, Lake Sidney Lanier Marina slip renter survey, $1999(\mathrm{~N}=208)$.

Table 7. Boat length and motor cross-tabulation, Lake Sidney Lanier Marina slip renter survey, 1999 ( $N=209)$.

Table 8. Summary of Lake Sidney Lanier Marina slip renters'/users' spending and use profiles, 09/1998 to 08/1999 (spending per party trip)...

Table 9. Spending and use by length of stay segments, Lake Sidney Lanier Marina slip renter survey, 09/98 to 08/99 (spending per party trip).

Table 10. Spending and use by boat length segments, Lake Sidney Lanier Marina slip renter survey, 09/98 to 08/99 (spending per party trip).

Table 11. Total annual use figures for marina slip renter survey at Lake Sidney Lanier (1999).

Table 12. Total trip spending in local area by Lake Sidney Lanier Marina slip renters/users (1999)

Table 13. Total trip spending by Lake Sidney Lanier Marina slip renters/users (1999). 26

Table 14. Total spending on fixed, annual goods and services by marina slip renters at Lake Sidney Lanier (1999).

Table 15. Regional economic impacts of Lake Sidney Lanier Marina slip renters'/users' trip spending (1999, for trip spending within 30 miles only).

Table 16. Regional economic impacts of Lake Sidney Lanier Marina Slip renters' durable goods and annual spending (1999)

Table 17. Regional economic impacts of Lake Sidney Lanier Marina slip renters'/users' trip and renters' annual spending (in 2004 dollars, for spending within 30 miles only).

Table 18. Number of trips to Lake Sidney Lanier private boat docks the previous year (09/01/1998 to 08/31/1999).

Table 19. Recreation activity participation during previous year's trips to Lake Sidney Lanier private boat docks, (09/01/1998 to 08/31/1999). 
Table 20. Boat type and length cross-tabulation, Lake Sidney Lanier private dock owner survey, $1999(\mathrm{~N}=277)$..

Table 21. Boat type and motor cross-tabulation, Lake Sidney Lanier private dock owner survey, 1999 ( $N=276)$

Table 22. Boat length and motor cross-tabulation, Lake Sidney Lanier private dock owner survey, $1999(\mathrm{~N}=272)$.

Table 23. Summary of Lake Sidney Lanier private dock owners'/users' spending and use profiles, 09/1998 to 08/1999 (spending per party trip).

Table 24. Spending and use by length of stay segments, Lake Sidney Lanier private dock owner survey, 09/1998 to 08/1999 (spending per party trip).

Table 25. Spending and use by boat length segments, Lake Sidney Lanier private dock owner survey, 09/1998 to 08/99 (spending per party trip).

Table 26. Total annual use figures for private dock owner survey at Lake Sidney Lanier (1999).

Table 27. Total trip spending in local area by Lake Sidney Lanier private dock owners/users (1999)

Table 28. Total trip spending by Lake Sidney Lanier private dock owners/users (1999).

Table 29. Total spending on fixed, annual goods and services by private dock owners at Lake Sidney Lanier (1999).

Table 30. Regional economic impacts of Lake Sidney Lanier private dock owners'/users' trip spending (1999, for trip spending within 30 miles only).

Table 31. Regional economic impacts of Lake Sidney Lanier private dock owners' durable goods and annual spending (1999).

Table 32. Regional economic impacts of Lake Sidney Lanier private dock owners'/users' trip and owners' annual spending (in 2004 dollars, for spending within 30 miles only). 55

Table 33. Demographic profiles of marina slip renters $(\mathrm{N}=211)$ and private dock owners $(\mathrm{N}=342)$ at Lake Sidney Lanier, 1999.

Table 34. Boating characteristics of marina slip renters $(\mathrm{N}=211)$ and private dock owners $(\mathrm{N}=342)$ at Lake Sidney Lanier, 1999. 57

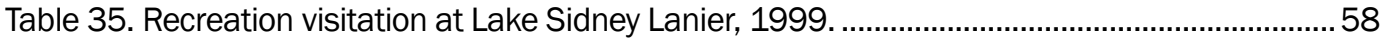

Table 36. Spending in local counties (within 30 miles of Corps boundary). ....................................58

Table 37. Trip characteristics (averages for last trip taken), Lake Sidney Lanier, 1999. ...................59

Table 38. Significance to local economy (trip spending, not durable goods), 1999.

Table 39. Direct impacts of an additional 1,000 marina slip renter party trips by segment, Lake Sidney Lanier. 


\section{Summary}

This report documents the local economic impacts of marina slip renters, and private dock owners and guests at Lake Sidney Lanier, located in northern Georgia and situated within the U.S. Army Corps of Engineers District, Mobile. This economic assessment is based on the results of a 1999 survey of the samples of Lake Sidney Lanier marina slip renters and private dock owners. Spending estimates are adjusted to 2004 dollars.

With its nearly 39,000 surface acres at summer pool, 700 miles of shoreline, 100 islands, and proximity to metropolitan Atlanta and the Georgia Blue Ridge Mountain, Lake Sidney Lanier is a popular tourist destination. Total tourism activity in the 16-county region surrounding Lake Sidney Lanier is $\$ 3.53$ billion, or 3.1 percent of all economic activity in that region.

Its high water quality and scenery make Lake Sidney Lanier highly desirable for the location of marinas, private homes and their associated private boat docks. The Corps of Engineers tallied nearly 5,900 marina slips and permitted over 8,000 private boat docks at Lake Sidney Lanier in 1999.

In 1999, marina slip renters/users contributed 198,417 party trips, or 7.6 percent of the total recreation usage, at Lake Sidney Lanier. Marina slip renters/users spent $\$ 33$ million in the local area on trip-related items (gasoline, meals, lodging, etc.) and $\$ 31$ million on new boats, slip rental fees, insurance, and other annual services. Together, $\$ 42$ million of the $\$ 64$ million in spending was captured by the region's economy as direct sales effects. This spending also generated $\$ 14$ million in direct personal income (wages and salaries) for local residents and supported 472 jobs in area tourism-related businesses. In 2004 dollars, these figures become $\$ 40$ million in trip-related expenditures and $\$ 38$ million in new boats and annual expenses. The associated economic effects-in 2004 dollars-are $\$ 51$ million in direct sales and $\$ 16.5$ million in direct personal income effects.

In 1999, private dock owners/users contributed 540,693 party trips, or 21 percent of the total recreation usage, at Lake Sidney Lanier. Private dock owners/users spent $\$ 51$ million in the local area on trip-related items 
(gasoline, meals, lodging, etc.) and \$21 million on new boats, dock maintenance, insurance, and other annual services. Together, \$45 million of this $\$ 72$ million in spending was captured by local economy as direct sales effects. This money also generated $\$ 18$ million in direct personal income (wages and salaries) for local residents and supported 749 jobs in area tourism-related businesses. In 2004 dollars, these figures become $\$ 61$ million in trip-related expenditures and $\$ 25$ million in new boats and annual expenses. The associated economic effects-in 2004 dollars-are \$54 million in direct sales and \$22 million in direct personal income effects.

The \$42 million direct sales effect associated with Lake Sidney Lanier slip renter/user spending is about 1.2 percent of all tourism activity $(\$ 3.53$ billion) in the 16-county region. Similarly, the $\$ 45$ million of direct sales effect associated with private dock owner/user spending is about 1.3 percent of the tourism activity ( $\$ 3.53$ billion) of the 16-county region (sales have been price inflated for this computation).

The above figures are direct effects only. Another $\$ 25$ million in sales (\$31 million in sales in 2004 dollars) from slip renters/users and \$27 million (\$33 million in sales in 2004 dollars) from private dock owners/users is generated through secondary effects, as slip renter/user and dock owner/user spending circulates through the local economy. While the direct effects accrue primarily to the retail trade sector, restaurants, manufacturing (mainly because of new boat purchases locally), and services, secondary effects benefit a wide range of local businesses.

Visitor segmentation is useful for planning purposes. This report provides results for the full samples of marina slip renters/users and private dock owners/users and for marina slip renter (private dock owner) segments that are useful for planning purposes: day use vs. overnight stay marina slip renters (private dock owners) and marina slip renters (private dock owners) in three boat size classes. For marina slip renters/users, day use and overnight stay segments were nearly even split in the sample (48 percent day users, 52 percent of slip users spent a least one night in the area on their last trip). In terms of total spending in the local region, day use slip users contributed 18 percent, and overnight stay slip users, 82 percent. Half the sample had medium-sized boats ( 25 to $35 \mathrm{ft}$ ), while a quarter were small (under $25 \mathrm{ft}$ ) and a quarter were large (above $35 \mathrm{ft}$ ). Slip users with large boats contributed 48 percent of total spending locally, 
slip users with medium-sized boats, 39 percent, and those with small boats, 13 percent.

For private dock owners/users, there were more than three times as many day users as overnight visitors in the sample ( 78 percent versus 22 percent, respectively). In terms of total spending in the local region, day use dock users contributed 67 percent, and overnight stay dock users, 33 percent. Forty-two percent of the sample had medium-sized boats (21 to $30 \mathrm{ft}$ ), while more than half were small (under $21 \mathrm{ft}$ ), and 3 percent of the boats were $31 \mathrm{ft}$ and longer. Dock users with large boats contribute 11 percent of total spending locally, dock users with medium-sized boats, 43 percent, and those with small boats, 46 percent.

The economic impacts estimated for Lake Sidney Lanier are useful for accountability purposes, lake support, and explaining the role of the lake in the region's economy. This report demonstrates how the results can also be used to evaluate management alternatives and strategies and to conduct sensitivity analyses. 


\section{Foreword}

This report represents one of nine market segmentation studies conducted at Corps of Engineers (Corps) water resources projects (lakes). The economic impact studies were conducted in 1999 and the information has been converted to 2004 dollars. It should be noted that no single study provides a complete portrait of any lake's boating market. The studies were limited to three market segments: marina slip renters, private dock, and community dock owners. These three groups do not reflect the spectrum of boating usage or market segments at any one of the lakes studied. The primary purpose of the studies was to obtain an understanding of these three market segments.

In addition to recreation usage, each of these segments is handled under different real estate instruments or shoreline use permit instruments. Marina slips (one boat per slip) are handled by the Corps at the marina facility level. Individual marina operators (lease holders) were involved in the development of contact lists for individual slip renters. Private dock owners (one dock permit, one household, potentially multiple boats) have a direct shoreline-use permit with the Corps and pay a fee. Community docks (one dock permit, multiple households, one boat per slip, a single household may hold multiple slips) are not tied to a single household but to a group of homes within a community. This permit type has a single point of contact (e.g. homeowner association). Typically the fee for a private or community dock permit is between $\$ 30$ and $\$ 35$ for 5 years. Additional administrative fees may also be collected to recover the cost of administration inspections and processing of permits; the cost is variable.

The lakes and market segments studied were:

- Table Rock Lake, community dock

- Rough River Lake, community dock

- Pomme de Terre Lake, community dock

- Harry S. Truman Dam and Reservoir, marina

- Raystown Lake, marina

- Hartwell Lake, private dock

- Lake Barkley, private dock

- Lake Sidney Lanier, private dock and marina 
Each of the lakes studied has a variety of boating and water usage issues that were not a part of this economic impact evaluation. This economic impact assessed recreation visitor trip spending and annual durable goods-related expenditures. In order to provide managers with a tool to assess the effects of management, this report outlined the spending categories of boat owners and visitors associated with the recreational trip under study. Examples are provided illustrating changes in the number of boat trips and the changes that could be seen in economic impacts. These are provided as illustrations. The same illustration can be used by managers to help assess low water conditions and boating trips lost, to get a sense of the change in economic impacts. This study did not include the impacts of additional boats over time to determine changes in use, water quality, social or environmental impacts, or the like. This study did not include changes in use based on increases in gasoline prices or technological changes in boating products. These are elements outside the study parameters and would serve as useful points of departure for further research. These reports should be evaluated in part with the larger boating usage that occurs at the individual lake and the changes that have occurred over time (including expenditure changes such as the increasing cost of gasoline). They serve in part to document a baseline, which in part justifies publication at this late date.

For example, at a single lake, boating utilization should be evaluated within a larger context of the multipurpose mission of each of the lakes. To get an understanding of historical use and issues at Corps of Engineers facilities, the following documents have been recommended for further study: national and state regulations, project master-planning documents, shoreline management plans, environmental assessments, and other local studies. Consult the local project manager for an assessment of other documents that should be considered in addition to the ones provided. 


\section{Preface}

The work reported herein was undertaken for the "Measuring the Economic Effects of Boat Dock Permit and Marina Slip Holders" work unit of the Recreation Management Support Program (RMSP). The RMSP is funded by the Operations and Maintenance (O\&M) General Appropriation and encompasses activities previously conducted through the Recreation Research Program and the Natural Resources Technical Support Program. The U.S. Army Engineer Research and Development Center (ERDC) provides program management support for execution of approved RMSP activities. The RMSP is managed at ERDC by Scott Jackson, Environmental Laboratory (EL). Kathleen Perales has served as Principal Investigator of the work unit since its creation in 1995.

This report documents a joint effort between ERDC and Michigan State University under contract with the United States Department of Agriculture to conduct lake level investigations on the economic spending patterns of visitors to communities, private boat docks, and marinas on Corps of Engineers water resources projects.

A Recreation Leadership Advisory Team (RLAT) provides oversight for the RMSP. The team has representatives from each Major Subordinate Command/Regional Office within the Corps of Engineers. In addition, four district offices and four project offices are represented. Donald Dunwoody, RLAT representative from the Northwestern Division, served as proponent for this work unit.

This report was prepared by Benoni Amsden and Dr. Dennis Propst of Michigan State University under USDA contract. Dr. Wen-Huei Chang, ERDC, performed all economic impact analyses. Dr. LiChu Lee, ERDC, served to verify all data elements. Richard Kasul, ERDC, and Kathleen Perales, ERDC, were responsible for the design, instrumentation, sampling frame, and contract oversight. This work was conducted under the general supervision of Scott Jackson, Acting Chief, Ecological Resources Branch (ERB); Dr. David Tazik, Chief, Ecosystem Evaluation and Engineering Division (EEED); and Dr. Beth Fleming, Director, EL. 
Peer reviewers of this report were Erwin Topper, Retired, Natural Resources Manager, Lake Sidney Lanier, USACE, and Patrick O. Taylor, Assistant Operations Project Manager, Lake Sidney Lanier, USACE.

COL Richard B. Jenkins was Commander and Executive Director of ERDC. Dr. James R. Houston was Director. 


\section{Introduction}

This report documents the local economic impacts of marina slip users and private dock ${ }^{1}$ users at Lake Sidney Lanier, located in northern Georgia. These estimates are then adjusted to 2004 dollars. Economic impacts are measured as the direct and secondary sales, income, and jobs in the local area resulting from spending by those who use marina slips and private docks. The economic estimates are produced using the Recreation Economic Assessment System (REAS) (Chang et al. 2001). Three major inputs to the model are:

- number of visits broken down into day use/overnight segments and three boat size segments

- spending averages for each segment

- economic multipliers for the local region

Inputs are derived from results contained in this report, the Natural Resource Management System (NRMS) database (U.S. Army Corps of Engineers (USACE 2006c)), and IMPLAN input-output modeling software (Minnesota IMPLAN Group 1996). The REAS model (USACE 2006a) provides a spreadsheet template for combining marina slip user and private dock user visitation data, spending and regional multipliers to compute changes in sales, personal income, jobs and value added in the region.

\section{Lake Sidney Lanier}

Constructed in 1957, Lake Sidney Lanier is a multiple purpose reservoir located in the foothills of the Blue Ridge Mountains in northern Georgia (Figure 1). At summer pool, Lake Sidney Lanier encompasses 39,038 surface acres. The lake is formed by Buford Dam, which impounds waters of the Chattahoochee and Chestatee Rivers to provide flood control, hydroelectric power, navigation, water supply, water quality, recreation, and fish and wildlife objectives.

\footnotetext{
1 Private Docks: A private dock is one that serves only one property owner. These docks should be permitted under the authority of ER 1130-2-406 (USACE 1999). Do not include commercial docks or marinas.

Community Docks: Community docks are privately owned, multi-slip facilities shared and used by several groups of people. These docks should be permitted under the authority of ER 1130-2-406 (USACE 1999). Do not include commercial docks or marinas (USACE 2006c).
} 


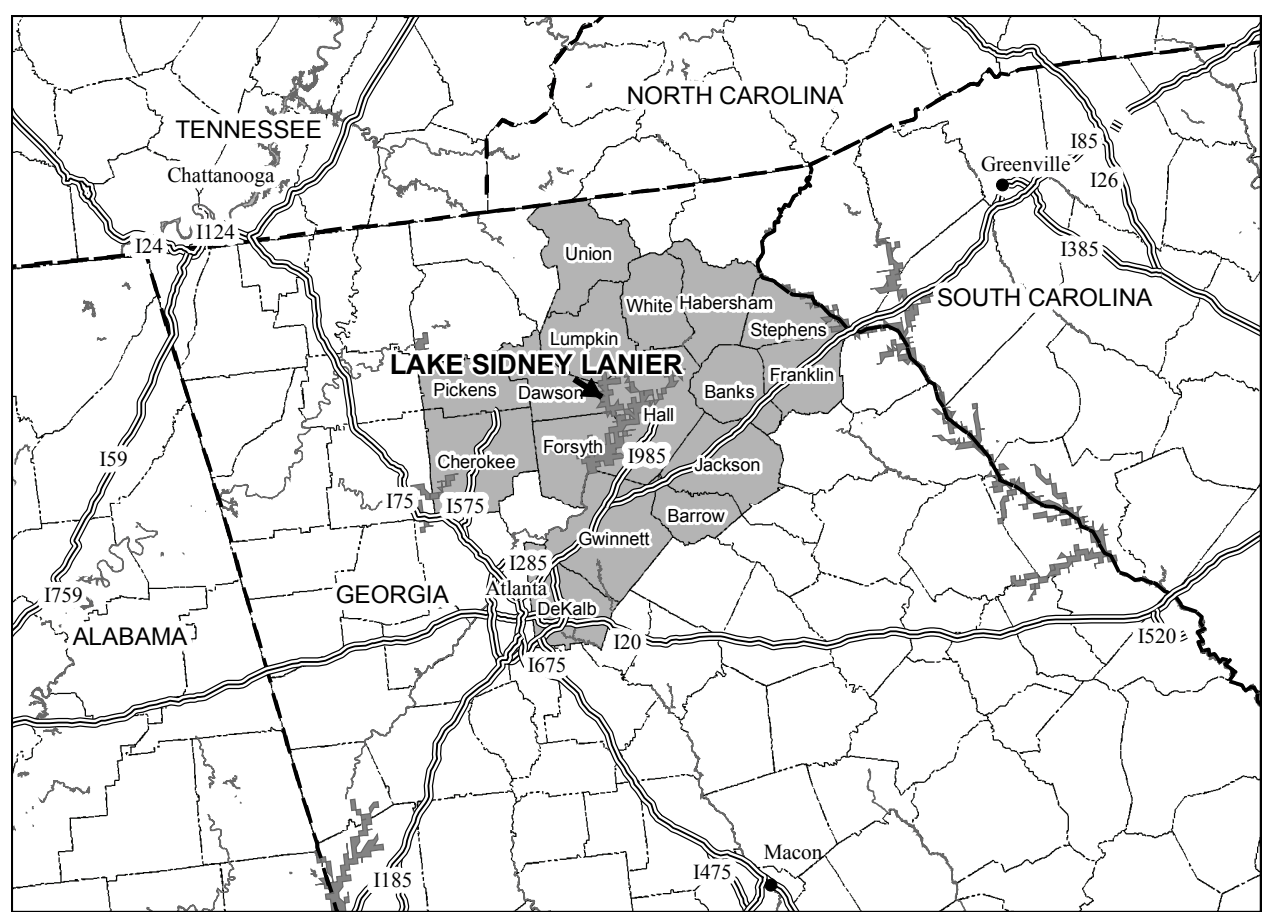

Figure 1. Lake Sidney Lanier and the surrounding region.

Lake Sidney Lanier (USACE 2006b) is one of the most popular recreational resources managed by the Corps of Engineers. One of the reasons for the lake's popularity is its proximity to metropolitan Atlanta. Most visitors who use the lake are from Atlanta and surrounding communities.

The Corps operates 46 park areas around Lake Sidney Lanier, providing facilities for boating, camping, picnicking, swimming, and other waterrelated activities. Included in these areas are 5 fee campgrounds and numerous day use recreation areas. On its 692 miles of shoreline, there are 78 boat ramps and 10 full-service marinas. Other organizations have campgrounds on Lake Lanier fee lands, such as Lake Lanier Islands (1), Hall County (1) and Don Carter State Park (1). Combined with these features, over 100 small islands and a reputation for high water clarity make Lake Sidney Lanier a highly desirable tourism and housing development location.

Lake Sidney Lanier hosted 7.7 million recreation visits in 1999, 96 percent of which were by day users (Table 1, top row). Non-boaters accounted for 4.8 million of total day use visits, and boaters another 2.6 million. Since visitor spending and economic impacts in this report are based on partydays or nights, these figures are shown on the bottom row of Table 1. In 1999, there were nearly 3 million party-days of recreation use. 
Table 1. Summary of recreation visits to Lake Sidney Lanier, 1999.

\begin{tabular}{|c|c|c|c|c|c|c|c|}
\hline & \multicolumn{2}{|c|}{ Camper $^{1}$} & \multicolumn{2}{|c|}{ Day User ${ }^{2}$} & \multicolumn{2}{|c|}{ Other Overnight ${ }^{3}$} & \multirow[b]{2}{*}{ Total } \\
\hline & Boat & $\begin{array}{l}\text { Non- } \\
\text { Boat }\end{array}$ & Boat & $\begin{array}{l}\text { Non- } \\
\text { Boat }\end{array}$ & Boat & $\begin{array}{l}\text { Non- } \\
\text { Boat }\end{array}$ & \\
\hline Visits (Person-Trips, 1000s) & 27.7 & 51.4 & $2,577.8$ & $4,787.4$ & 77.3 & 143.6 & $7,665.2$ \\
\hline Average Length of Stay (Days) & 4.2 & 3.8 & - & - & 2.4 & 3.0 & - \\
\hline Average Party Size & 3.5 & 2.8 & 2.8 & 2.8 & 3.3 & 2.5 & - \\
\hline Visits (Party-Days, 1000s) & 33.3 & 71.0 & 926.0 & $1,730.3$ & 57.2 & 174.2 & $2,991.9$ \\
\hline \multicolumn{8}{|c|}{$\begin{array}{l}1 \text { Number of campers in party days was derived from the } 1998 \text { NRMS (USACE 2006c), CUR_FEE database (the last year that } \\
\text { camper revenue data is available) by dividing total camping revenue by an average of } \$ 8.00 \text { per party day camping fee and ex- } \\
\text { panding by the number of non-Corps managed campsites. The number of camper party-days was then adjusted to } 1999 \text { by mul- } \\
\text { tiplying the ratio of } 1999 \text { visits to } 1998 \text { visits from the PR_USE database. Then, party-days were converted to person-trips by the } \\
\text { following formula: Number of campers in person-trips = number of party-days times average party size/average length of stay. } \\
\text { Percent of boaters was obtained from the NRMS, PR_USE database. Party Size and Length of Stay figures are based on the re- } \\
\text { sults of a national survey (Chang et al. 2003). }\end{array}$} \\
\hline \multicolumn{8}{|c|}{$\begin{array}{l}2 \text { Number of day users in person-trips was derived from the } 1999 \text { NRMS (USACE 2006c), PR_USE database by subtracting } \\
\text { camper visits from total visits. Then, number of day users in party-days = number of person-trips times average length of stay/ } \\
\text { average party size. Percent of boaters was obtained from NRMS, PR_USE database. }\end{array}$} \\
\hline
\end{tabular}

\section{The Local Region}

Sixteen counties comprise the local economic impact study region for Lake Sidney Lanier. ${ }^{1}$ Compared to many other regions around the Corps projects, this is an economically large and diverse area. According to the U.S. Census Bureau (2006), the population for these counties is 1,914,908 (1999) or 2,165,013 (2004 estimate), with an average median household income of $\$ 43,886$ (1999). This can be compared to a statewide population of 8,186,453 (1999) or 8,829,383 (2004 estimate) and median household income of $\$ 42,433$ (1999).

The Construction, Manufacturing, Other Services, and F.I.R.E. (Finance, Insurance, and Real Estate) sectors are the principal economic base of the area, combining to account for 60 percent of sales, 51 percent of jobs, and 53 percent of compensation in the sixteen-county region (Table 2). An estimate of total tourism sales in the 16 counties is $\$ 3.53$ billion (Table 2:

\footnotetext{
1 The counties are Banks, Barrow, Cherokee, Dawson, De Kalb, Forsyth, Franklin, Gwinnett, Habersham, Hall, Jackson, Lumpkin, Pickens, Stephens, Union, and White.
} 
100 percent of hotel/motel +100 percent of amusement and recreation + 25 percent of restaurant +25 percent of retail sales). ${ }^{1}$ In 2000 , hotel sales in the area were $\$ 1.2$ million, supporting 12,292 jobs in the hotels and lodging sector (Minnesota IMPLAN Group 2000).

Table 2. Economic activity in the Lake Sidney Lanier region, 2000.

\begin{tabular}{|l|r|r|r|r|r||}
\hline Industry & $\begin{array}{c}\text { Output } \\
\text { (\$ millions) }\end{array}$ & Employment & $\begin{array}{c}\text { Employee } \\
\text { Compensation } \\
\text { \$ millions) }\end{array}$ & $\begin{array}{c}\text { Value Added } \\
\text { (\$ millions) }\end{array}$ & \% Output \\
\hline Agriculture, forestry, fish & $1,561.85$ & 19,592 & 166.83 & 519.10 & $1 \%$ \\
\hline Mining & 150.15 & 1,073 & 50.68 & 92.21 & $0.1 \%$ \\
\hline Construction & $11,545.25$ & 97,151 & $2,980.43$ & $4,287.15$ & $10 \%$ \\
\hline Food processing & $3,391.81$ & 19,134 & 596.08 & 883.74 & $3 \%$ \\
\hline Apparel & 938.52 & 7,532 & 247.70 & 324.41 & $1 \%$ \\
\hline Manufacturing & $20,251.63$ & 90,167 & $4,949.09$ & $7,605.61$ & $18 \%$ \\
\hline Sporting goods & 198.18 & 883 & 33.74 & 51.95 & $0.2 \%$ \\
\hline Auto parts and access & 617.89 & 2,719 & 118.35 & 161.17 & $1 \%$ \\
\hline Transp. and commu. & $8,961.36$ & 44,647 & $2,002.96$ & $4,928.36$ & $8 \%$ \\
\hline Other services & $20,012.18$ & 288,859 & $9,507.72$ & $13,147.68$ & $18 \%$ \\
\hline Wholesale trade & $12,601.90$ & 86,951 & $5,186.58$ & $8,756.86$ & $11 \%$ \\
\hline Retail & $6,646.10$ & 130,899 & $3,083.35$ & $5,301.37$ & $6 \%$ \\
\hline Eating and drinking & $2,035.02$ & 52,908 & 760.69 & $1,112.12$ & $2 \%$ \\
\hline Finance, insurance and real & $16,343.53$ & 77,736 & $2,690.19$ & $11,441.95$ & $14 \%$ \\
\hline estate & $1,167.41$ & 12,292 & 459.63 & 773.35 & $1 \%$ \\
\hline Hotels and lodging places & 982.97 & 11,271 & 276.22 & 595.83 & $1 \%$ \\
\hline Auto services & 664.09 & 10,309 & 261.79 & 345.33 & $1 \%$ \\
\hline Other amusements & 193.21 & 8,140 & 72.38 & 118.26 & $0.2 \%$ \\
\hline Amusement and rec services & $5,988.86$ & 123,874 & $4,705.96$ & $5,563.00$ & $5 \%$ \\
\hline Gov't and other & $114,251.92$ & $1,086,137$ & $38,150.35$ & $66,009.45$ & $100 \%$ \\
\hline Total & & & & \\
\hline \hline Source: IMPLAN, 2000 county data files for the 16-county regions. & & & & \\
\hline \hline
\end{tabular}

1 An independent Travel Industry Association of America estimate of tourism activity in the same region for 2002 is $\$ 2.15$ billion, accessed from the following sources: Georgia.org Travel, Table 3.4: Economic Impact of Domestic Travel in Georgia by Region and County -2002 of "2002 Economic Impact of Tourism on Georgia- Regional \& County Analysis - County Level Data Only," Tourism Industry Research, http://my.georgia.org/net/content/page.aspx?s=72591.72586.26.3011 (accessed May 22, 2006). 


\section{Marina Slip Renter and Private Dock Owner Survey, 1998-99}

The Ecological Resources Branch (ERB) of the U.S. Army Engineer Research and Development Center (ERDC) surveyed marina slip renters at Lake Sidney Lanier (Georgia), Raystown Lake (Pennsylvania), and Harry S. Truman Dam and Reservoir (Missouri), and private docks at Lake Sidney Lanier (Georgia), Lake Barkley (Kentucky/Tennessee), and Hartwell Lake (Georgia/North Carolina/South Carolina). The ERB staff designed the surveys, constructed the instrument, and provided the frame (a list of marina slip renters and private dock owners) to the Institution for Public Policy and Social Research (IPPSR) at Michigan State University (MSU) for sampling. IPPSR obtained additional approval through MSU's Human Subjects Office. The office of Management and Budget authorized this study (Institute for Water Resources (IWR) 2006).

Working with the project managers, the ERB obtained lists of marina slip renters and private dock owners. Once the contact information was received, MSU IPPSR staff sent a pre-contact mailer to the slip renters and dock owners in the sample. This information packet included a description of the study and a FAQ sheet for the marina slip renter or private dock owner. In addition, the slip renters and dock owners received a worksheet outlining the spending categories and other information regarding the upcoming telephone interview. Calls were made to slip renters and dock owners in the randomly ordered sequence, until a quota of interviews were completed. In this manner, 211 randomly selected marina slip renters and 342 private dock owners were interviewed at Lake Sidney Lanier, representing 4.0 percent of the total of 5,319 eligible marina slips at the time of the survey ${ }^{1}$, and 4.3 percent of the 7,944 eligible private docks. ${ }^{2}$

Spending and trip information were obtained through a Computer Assisted Telephone Interview (CATI) survey conducted by MSU IPPSR staff. The slip renters and dock owners were asked to document the number of

\footnotetext{
${ }^{1}$ Five yacht clubs were eliminated from the possible sampling list at Lake Sidney Lanier. The rationale for their elimination was that they are not completely open to the public and yacht club members will thus have different expenditure and use patterns than marina slip renters. Marinas are open to the public. The five yacht clubs at Lanier provided an additional 558 slips at the time of the study (1998).

2 Number of marina slips and private docks derived from 1998 NRMS data.
} 
boating trips on the lake that originated from their marina or dock and to report trip spending associated with their most recent trip. Spending information was collected only for the most recent trip to reduce recall bias and avoid selective recall in which slip renters and dock owners may report spending on the most expensive trips. The telephone interview lasted an average of 15 minutes. Other information needed to estimate parameters for this population was also acquired during the interview. 


\section{Results - Marina Slip Renters}

Results are provided in four parts: respondent profiles (including socioeconomic characteristics); recreation trip characteristics (amount of boat use, recreation activities, and boat type); per-trip and annual spending; and the economic impacts of slip renters'/users' spending on the local region surrounding Lake Sidney Lanier.

\section{Respondent profiles}

The general characteristics of marina slip renters as individuals and by households at Lake Sidney Lanier are shown in Figures 2 to 11. In general, the marina slip renters were mostly white males with high education and income. Among the respondents, 89 percent were male and more than 60 percent were aged 46 and above (Figures 2 and 3). The average age was 49 (range $=28$ to 78 years old). The most frequent age (mode) was 52 . Ninety percent of the slip renters had at least some college education and 77 percent had college degrees or more. In fact, 26 percent of Lanier's marina slip renters held graduate degrees (Figure 4). Almost all of the renters interviewed were white (Figure 5). All marina slips have registered boats; surveys may or may not have been conducted with the registered boat owner. Ninety-two percent of the renters were also the registered boat owner at the time of the interview (Figure 6).

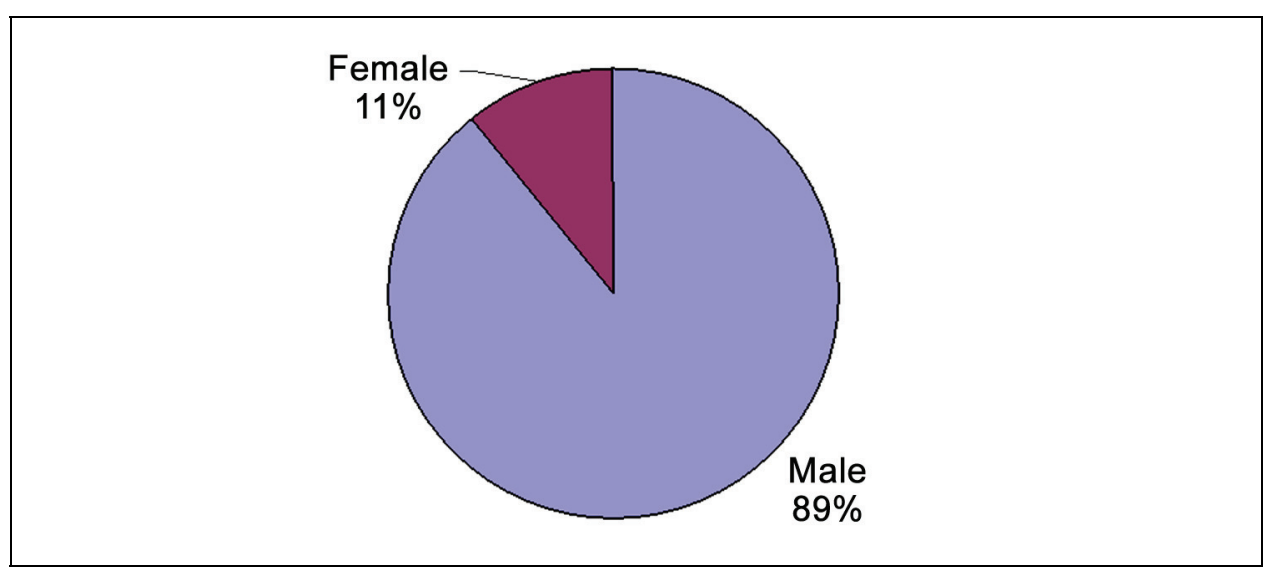

Figure 2. Gender of marina slip renters at Lake Sidney Lanier, 1999 (N=210). 


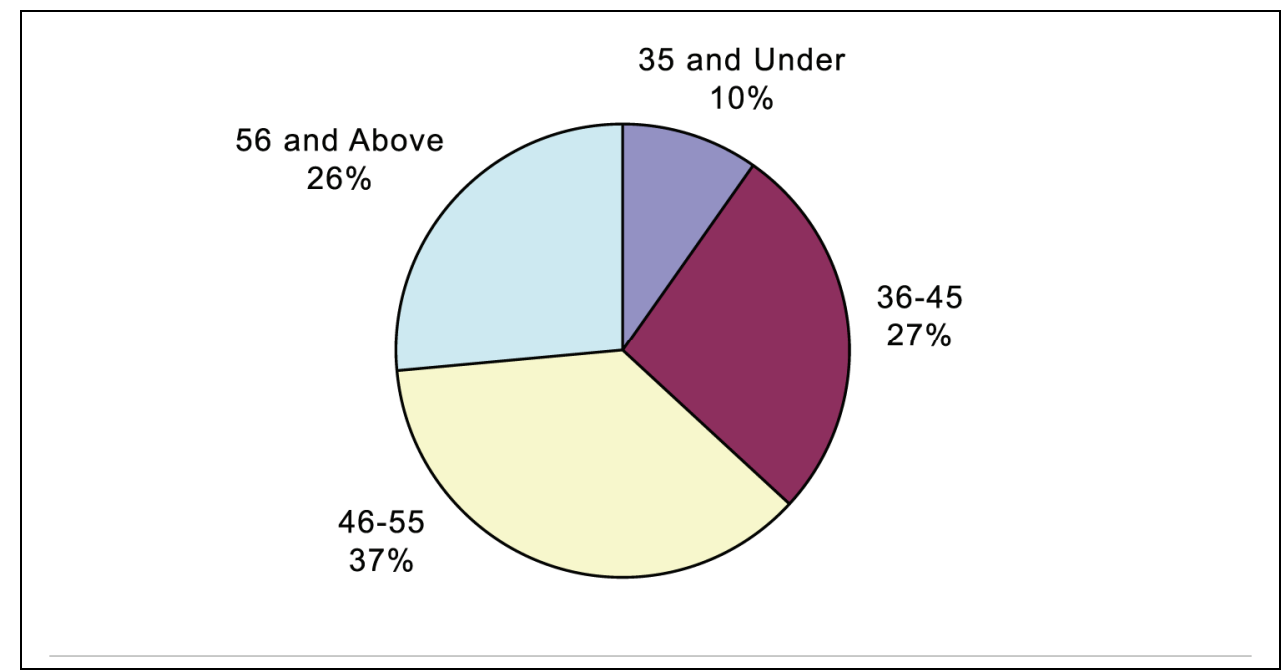

Figure 3. Age of marina slip renters at Lake Sidney Lanier, 1999 (N=208).

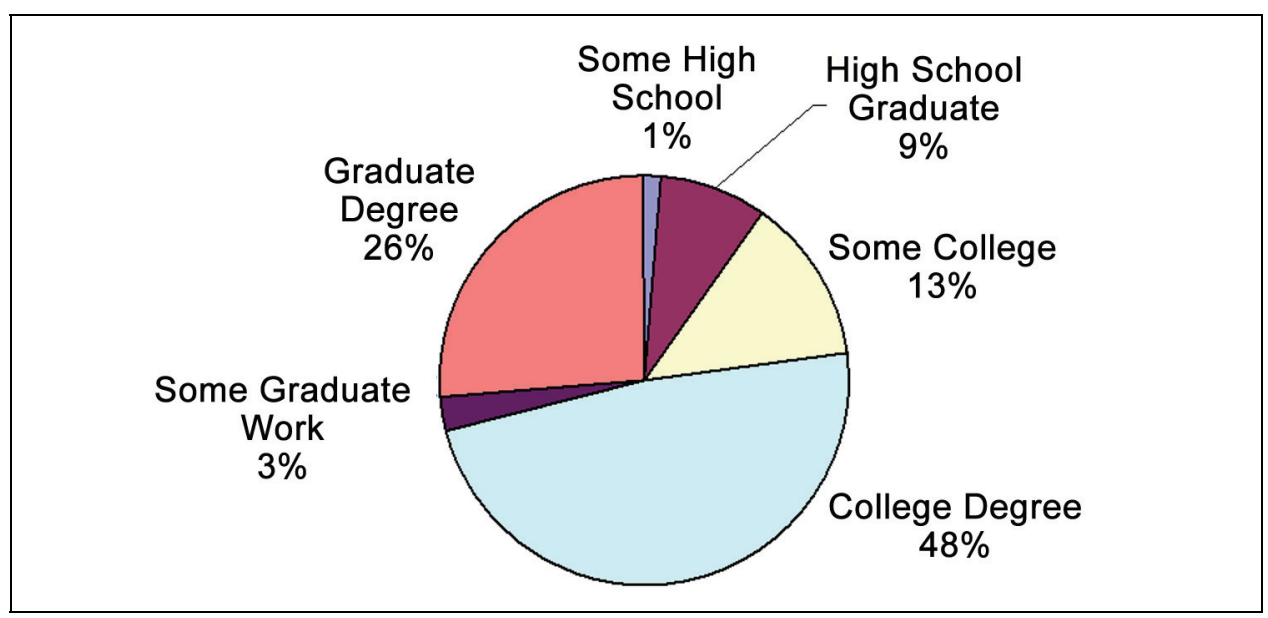

Figure 4. Education of marina slip renters at Lake Sidney Lanier, $1999(\mathrm{~N}=209)$.

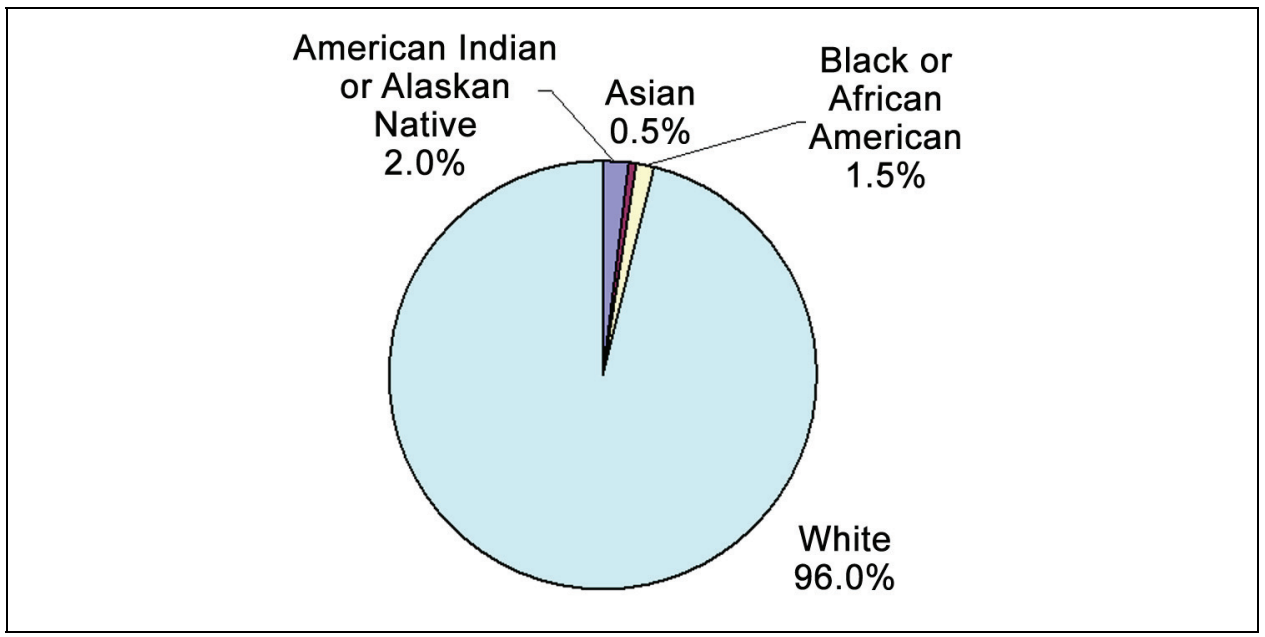

Figure 5. Race of marina slip renters at Lake Sidney Lanier, 1999 ( $N=199)$ (about 2 percent were Hispanic or of Latino origin). 


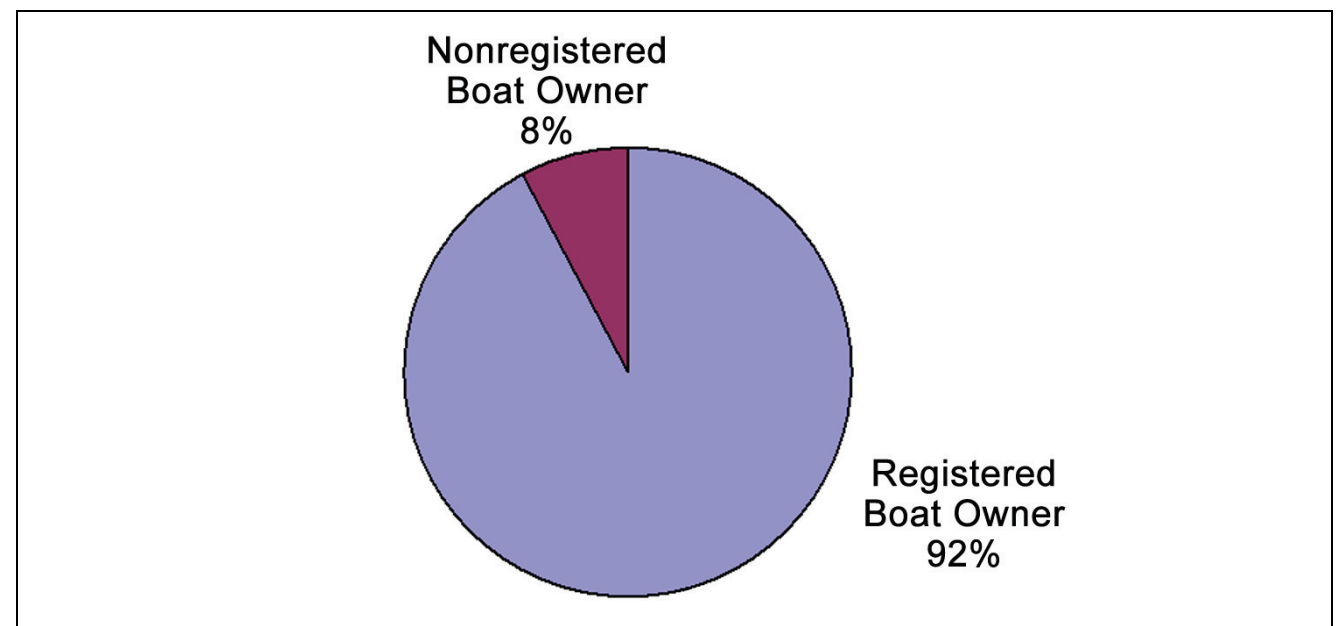

Figure 6. Survey conducted with registered boat owners at Lake Sidney Lanier Marina, $1999(\mathrm{~N}=209)$.

Most marina slip renters reported high household incomes with no or few children living in the household. Eighty percent of the respondents had annual household incomes of at least $\$ 80,000$, with 62 percent reporting incomes of over $\$ 100,000$ (Figure 7). More than half of the renters lived in a household with two or less people and 61 percent of the renters did not have any children age under 18 in their households (Figures 8 and 9). The average number of individuals per household was 2.8. The most frequent household size (mode) was 2.

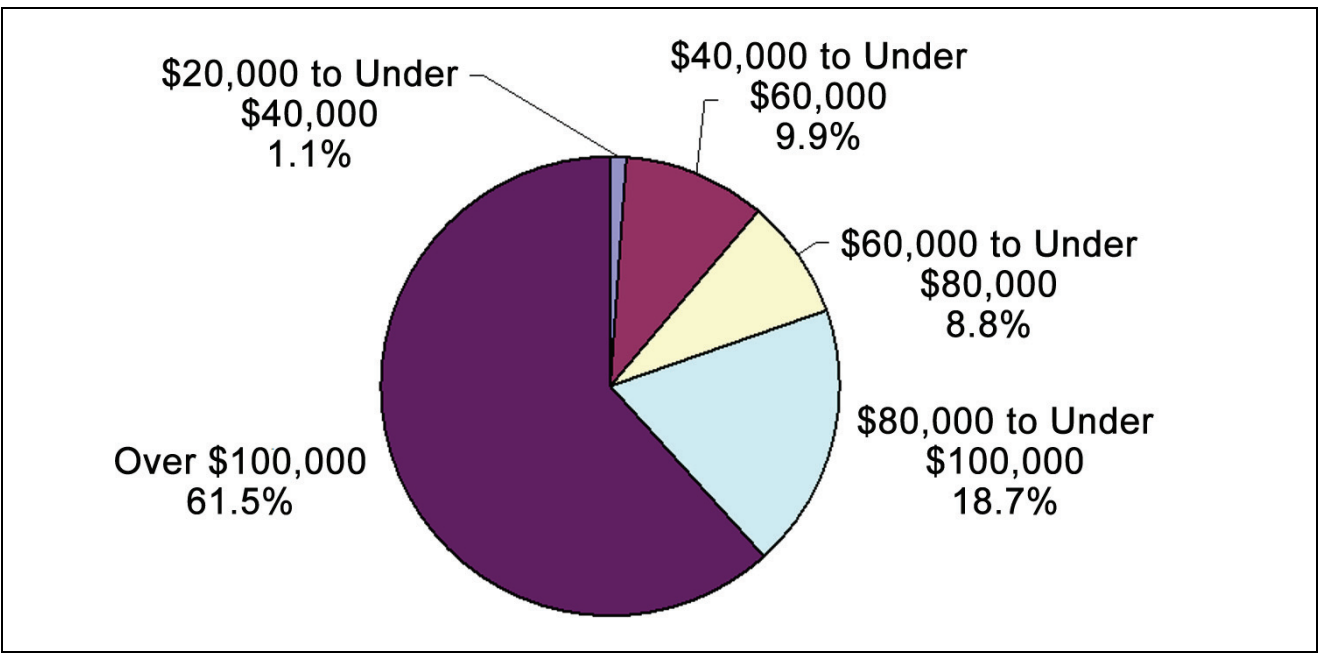

Figure 7. Household income of marina slip renters at Lake Sidney Lanier, 1999 (N=182). 


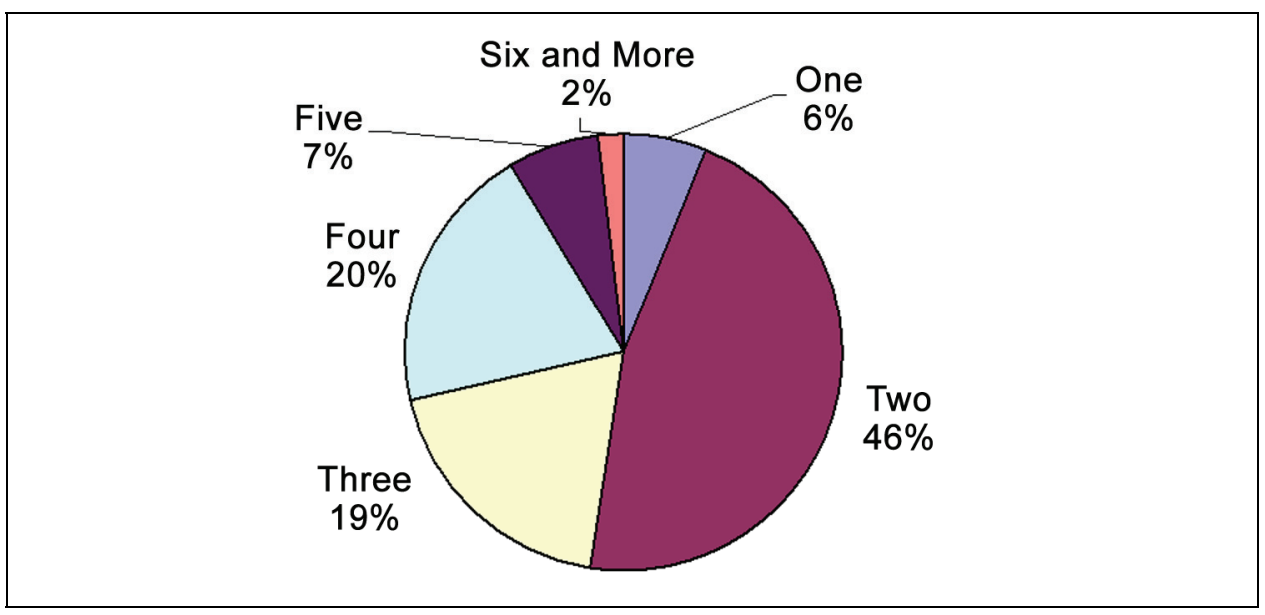

Figure 8. Household size of marina slip renters at Lake Sidney Lanier, 1999 ( $N=209)$.

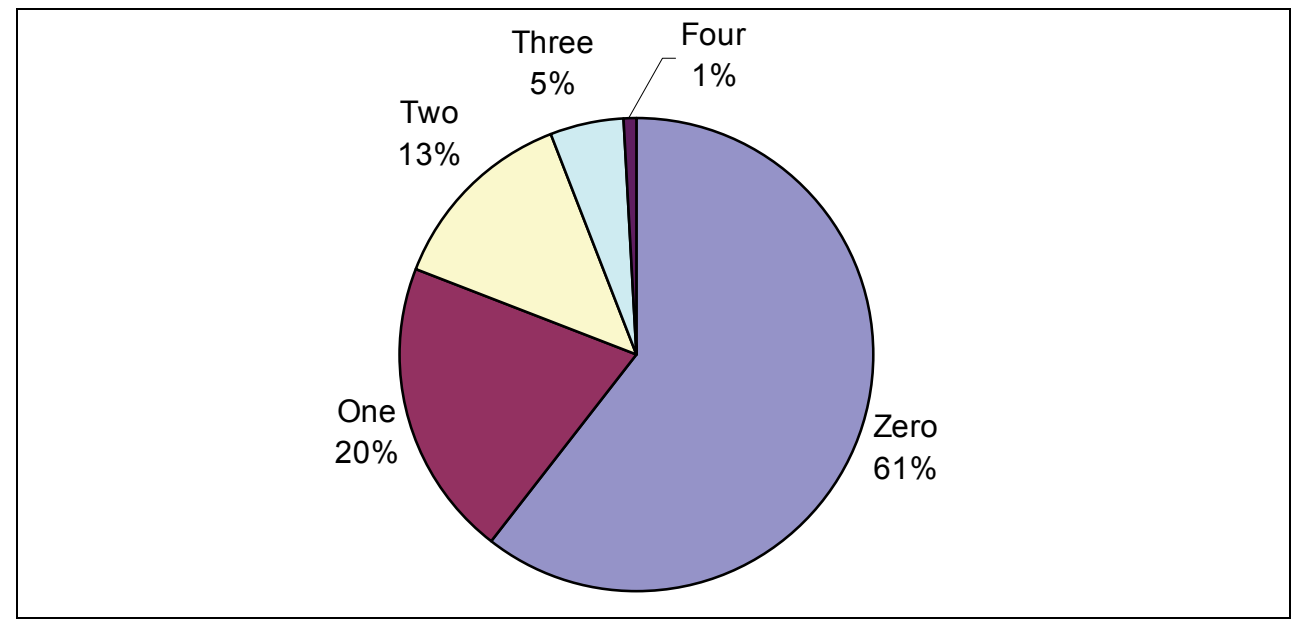

Figure 9. Number of people under 18 in households of marina slip renters at Lake Sidney Lanier, $1999(\mathrm{~N}=208)$.

The permanent residences of 55 percent of the renters were within 30 miles of the marina (Figure 10). The average distance from the slip renter's permanent home to the marina was 35 miles. Three percent of the slip renters owned a seasonal home within 30 miles of the marina (Figure 11). 


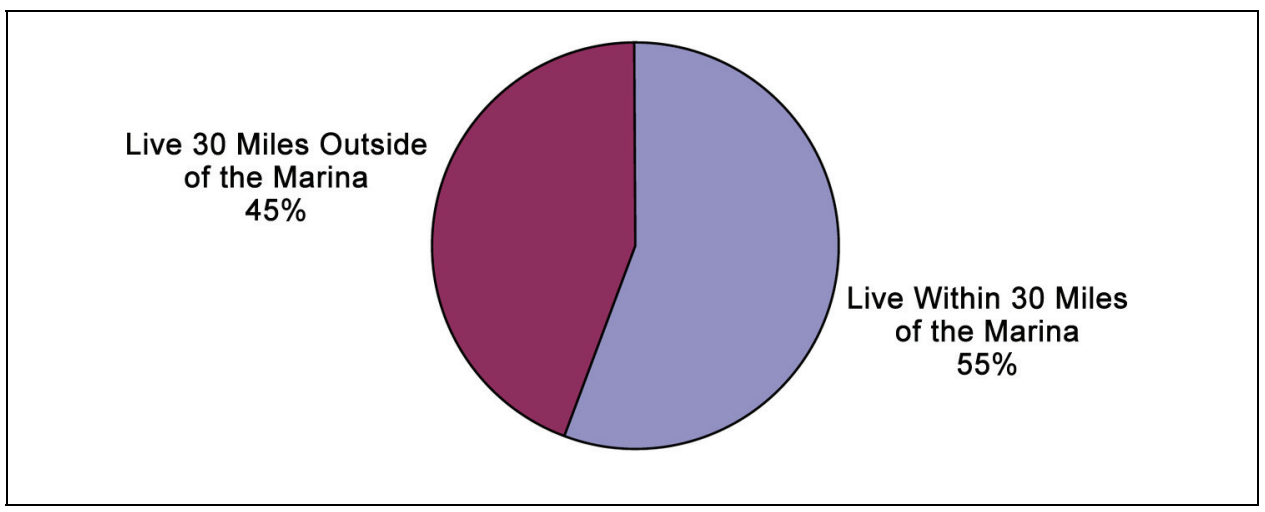

Figure 10. Permanent residence of marina slip renters at Lake Sidney Lanier, $1999(\mathrm{~N}=211)$.

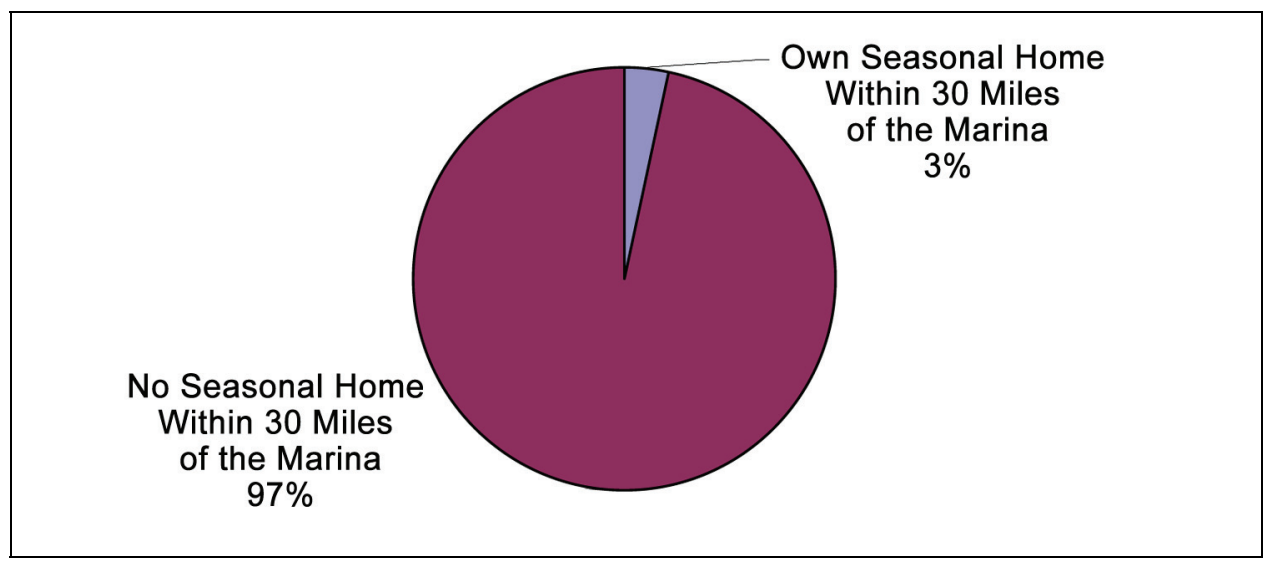

Figure 11. Seasonal home ownership of marina slip renters at Lake Sidney Lanier, $1999(\mathrm{~N}=211)$.

\section{Boating characteristics}

Respondents had been boating on Lake Sidney Lanier for an average of 10 years (range $=38$ years). On average, they and their guests (renters/users) took 35 boating trips the previous year from September 1, 1998 to August 31, 1999. ${ }^{1}$ Half of them made 26 or fewer trips and 25 percent made 41 or more trips in the same period (Table 3). The number of trips was nearly equal in three seasons: spring (10 trips), summer (10), and fall (9). On average, the fewest number of trips were made in the winter (6 trips per slip renter). When asked to compare the number of boating trips made last year to the previous three years, 56 percent of the renters felt that they had made about the same number of boating trips. Twelve percent said they had taken more trips last year than in the previous three years, and 32 percent said they had taken fewer trips (Figure 12).

\footnotetext{
1 Fifty-five percent of the sampled slip renters had permanent residences within 30 miles of their marina slip. Therefore a large proportion of trips are local in origin.
} 
Table 3. Number of boating trips to Lake Sidney Lanier Marina the previous year (09/01/1998 to 08/31/1999).

\begin{tabular}{|c|c|c|c|c|c|c|c|c|}
\hline & & & & & & rcentil & & \\
\hline & Average & Std. Error & Minimum & Maximum & $25 \%$ & $50 \%$ & $75 \%$ & $\mathrm{~N}$ \\
\hline Total number of trips & 35.17 & 2.39 & 0 & 198 & 15 & 26 & 41 & 208 \\
\hline Trips made in fall & 9.15 & 0.84 & 0 & 90 & 3 & 6 & 10 & 206 \\
\hline Trips made in winter & 5.69 & 0.59 & 0 & 60 & 0 & 3 & 8 & 206 \\
\hline Trips made in spring & 10.06 & 0.87 & 0 & 80 & 3 & 7 & 12 & 206 \\
\hline Trips made in summer & 10.12 & 0.71 & 0 & 90 & 4 & 8 & 13 & 206 \\
\hline
\end{tabular}

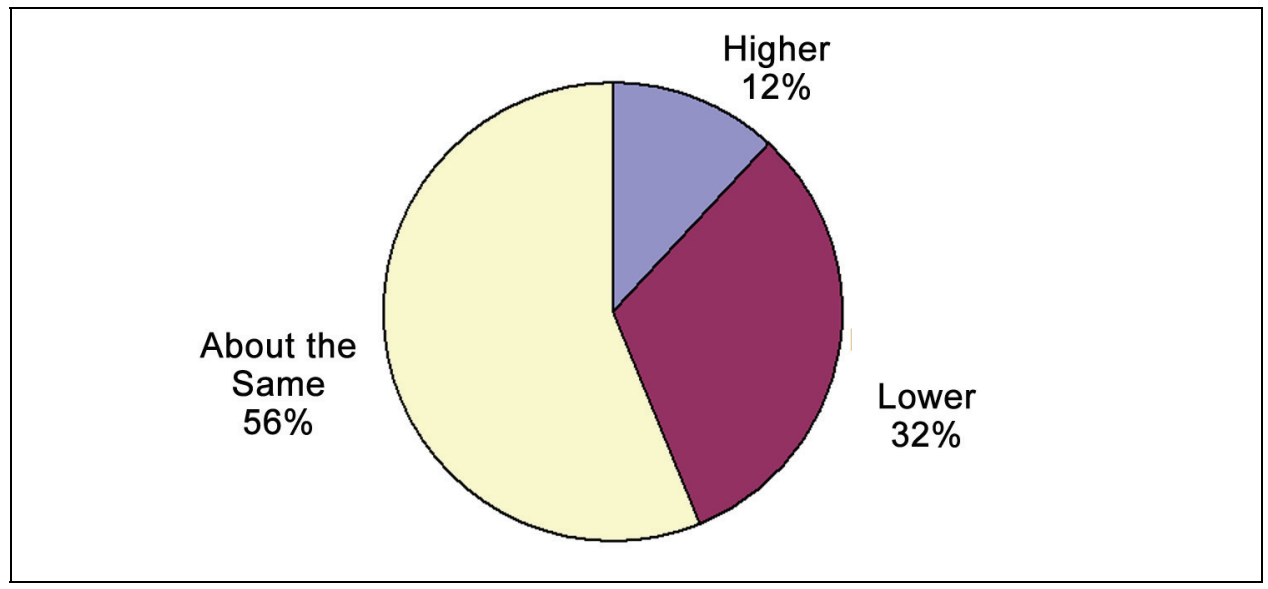

Figure 12. Number of boating trips made by marina slip renters last year compared to previous 3-year average at Lake Sidney Lanier, $1999(\mathrm{~N}=185)$.

\section{Activities while boating}

During their boating trips the previous year, slip renters/users went swimming an average of 18 times during half of their trips (Table 4). Other activities they participated in during their boating trips including picnicking (on 34 percent of their boating trips), fishing from boats (15 percent), water skiing (7 percent), and camping and hiking (5 percent each). The participation rates for scuba diving, fishing from shore, and hunting were all less than 5 percent of the total boating trips. Forty-six percent of the slip renters/users reported participating in other activities that were not mentioned during the telephone interviews (Figure 13). On average, slip renters/users participated in other activities eight times during 22 percent of their boating trips the previous year (Table 4). The most frequent other water activities were sailing (11 percent of respondents), tubing/wave running (6 percent), and jet skiing (6 percent) (Figure 13). 
Table 4. Recreation activity participation during previous year's boating trips to Lake Sidney Lanier Marina (09/01/1998 to 08/31/1999).

\begin{tabular}{|l|l|l|l|l|l|l||}
\hline Activity & Mean & $\begin{array}{l}\text { Percent of } \\
\text { total trips }\end{array}$ & $\begin{array}{l}\text { Std. Error } \\
\text { of Mean }\end{array}$ & Minimum & Maximum & N \\
\hline \hline Boating & 31.82 & $90 \%$ & 2.47 & 0 & 198 & 185 \\
\hline Swimming & 17.85 & $51 \%$ & 1.54 & 0 & 150 & 185 \\
\hline Picnicking & 12.12 & $34 \%$ & 1.41 & 0 & 140 & 186 \\
\hline Fishing from boat & 5.28 & $15 \%$ & 1.25 & 0 & 160 & 186 \\
\hline Water skiing & 2.45 & $7 \%$ & 0.40 & 0 & 30 & 184 \\
\hline Camping & 1.78 & $5 \%$ & 0.41 & 0 & 40 & 186 \\
\hline Hiking & 1.64 & $5 \%$ & 0.60 & 0 & 95 & 187 \\
\hline Fishing from shore & 1.06 & $3 \%$ & 0.32 & 0 & 50 & 186 \\
\hline Scuba diving & 0.38 & $1 \%$ & 0.16 & 0 & 25 & 186 \\
\hline Hunting & 0.37 & $1 \%$ & 0.37 & 0 & 70 & 187 \\
\hline Other activities & 7.79 & $22 \%$ & 1.12 & 110 & 190 \\
\hline \hline $\begin{array}{l}1 \\
2\end{array}$ \\
2 Times participated in listed activity during previous year's boating trip. \\
\hline
\end{tabular}

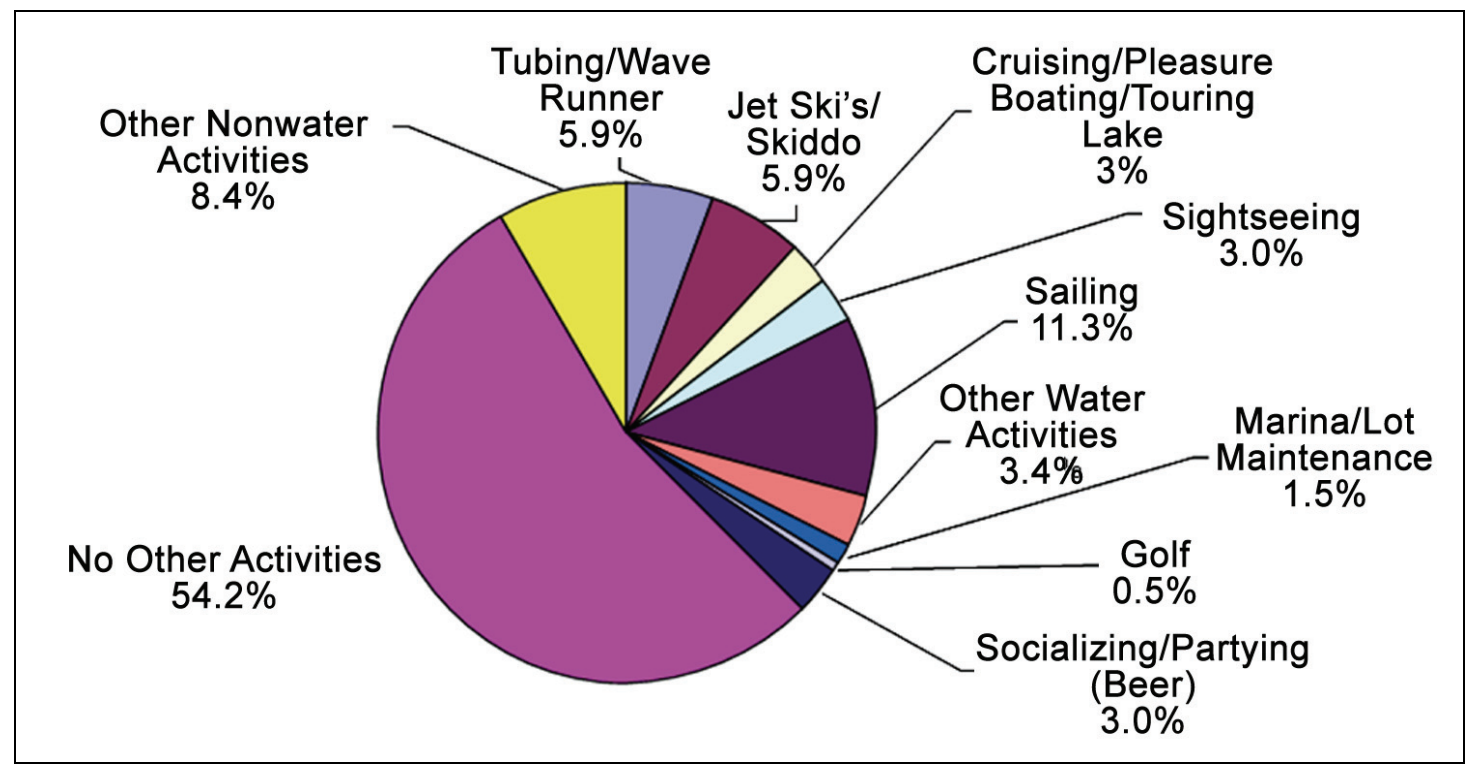

Figure 13. "What other activities did you or others participate in during your boating trips last year that I have not already mentioned?" (from Lake Sidney Lanier Marina, 1999, N=203). 


\section{Type of boat and motor}

Forty-nine percent of the boats surveyed at Lake Sidney Lanier marinas were 25 to $35 \mathrm{ft}$ long (Table 5). Twenty-eight percent were $24 \mathrm{ft}$ and under with a minimum of $8 \mathrm{ft}$, and 23 percent were $36 \mathrm{ft}$ and larger with a maximum of $90 \mathrm{ft}$. Open and pontoon boats were mostly $24 \mathrm{ft}$ and smaller, while cabin cruisers and sailboats were mostly 25 to $35 \mathrm{ft}$ long. All houseboats were $36 \mathrm{ft}$ and larger.

Table 5. Boat type and length cross-tabulation, Lake Sidney Lanier Marina slip renter survey, $1999(\mathrm{~N}=210)$.

\begin{tabular}{|c|c|c|c|c|c|c|c|}
\hline \multirow[b]{2}{*}{ Boat Length } & \multicolumn{6}{|c|}{ Boat Type } & \multirow[b]{2}{*}{ Total } \\
\hline & Open & Cabin & Sailboat & Pontoon & Houseboat & PWC & \\
\hline 24 ' and smaller & $7.14 \%$ & $4.29 \%$ & $11.43 \%$ & $3.81 \%$ & $0.00 \%$ & $0.95 \%$ & $27.62 \%$ \\
\hline $25^{\prime}$ to $35^{\prime}$ & $3.33 \%$ & $26.19 \%$ & $18.57 \%$ & $0.95 \%$ & $0.00 \%$ & $0.00 \%$ & $49.05 \%$ \\
\hline $36 '$ and larger & $0.00 \%$ & $9.05 \%$ & $2.38 \%$ & $0.00 \%$ & $11.90 \%$ & $0.00 \%$ & $23.33 \%$ \\
\hline Total & $10.48 \%$ & $39.52 \%$ & $32.38 \%$ & $4.76 \%$ & $11.90 \%$ & $0.95 \%$ & $100.00 \%$ \\
\hline
\end{tabular}

Sixty-three percent of the boats used at marinas had inboard motors. The majority of cabin cruisers, houseboats, and open boats had inboard motors, while most pontoons did not (Table 6). Sailboats were nearly evenly divided between in- and outboard motors. In general, the larger boats (25 feet and above) had the greater percentage of inboard motors (Table 7).

Table 6. Boat type and motor cross-tabulation, Lake Sidney Lanier Marina slip renter survey, $1999(N=208)$.

\begin{tabular}{|c|c|c|c|c|c|c|c|}
\hline \multirow{2}{*}{$\begin{array}{l}\text { Inboard } \\
\text { Motor }\end{array}$} & \multicolumn{6}{|c|}{ Boat Type } & \multirow[b]{2}{*}{ Total } \\
\hline & Open & Cabin & Sailboat & Pontoon & Houseboat & PWC & \\
\hline With & $8.17 \%$ & $31.73 \%$ & $14.42 \%$ & $0.48 \%$ & $7.21 \%$ & $0.96 \%$ & $62.98 \%$ \\
\hline Without & $2.40 \%$ & $7.69 \%$ & $18.27 \%$ & $4.33 \%$ & $4.33 \%$ & $0.00 \%$ & $37.02 \%$ \\
\hline Total & $10.58 \%$ & $39.42 \%$ & $32.69 \%$ & $4.81 \%$ & $11.54 \%$ & $0.96 \%$ & $100.00 \%$ \\
\hline
\end{tabular}


Table 7. Boat length and motor cross-tabulation, Lake Sidney Lanier Marina slip renter survey, $1999(\mathrm{~N}=209)$.

\begin{tabular}{|c|c|c|c|c|}
\hline \multirow[b]{2}{*}{ Inboard Motor } & \multicolumn{3}{|c|}{ Boat Length } & \multirow[b]{2}{*}{ Total } \\
\hline & 24 ' and smaller & $25^{\prime}$ to $35^{\prime}$ & 36 ' and larger & \\
\hline With & $11.48 \%$ & $33.01 \%$ & $18.18 \%$ & $62.68 \%$ \\
\hline Without & $16.27 \%$ & $15.79 \%$ & $5.26 \%$ & $37.32 \%$ \\
\hline Total & $27.75 \%$ & $48.80 \%$ & $23.44 \%$ & $100.00 \%$ \\
\hline
\end{tabular}

\section{Slip user segments and spending}

Spending averages were estimated for all Lake Sidney Lanier's marina slip users (Table 8) and for two different segments based on length of stay (Table 9) and boat length (Table 10). Dividing visitors into segments helps explain differences in spending across distinct user groups. It gives managers the opportunity to apply these distinct spending profiles to project level use data. The two types of segments that fulfilled these purposes were: day user versus overnight stay segments and segments based on length of the boat.

\section{Average spending for full sample of slip renters}

Marina slip users averaged $\$ 187$ in trip expenses associated with their last boating trip (for a party of 3.6 people). Slip users stayed away from home an average of 1.2 nights and used their boat 1.9 days during their last trip (Table 8). Eighty-nine percent (\$166) of spending occurred within 30 miles of their marina slip. Of the expenditures made within 30 miles of their marina slip, slip users spent the most on gas and oil for their boat (\$43 per party trip), followed by groceries (\$37), restaurant meals (\$29), and gas and oil for their vehicles (\$19). An average of 35 boating trips were made from each slip in a marina during the previous year.

Slip renters spent an average of $\$ 2,259$ annually on slip rentals, $\$ 92$ on storage fees, $\$ 510$ on insurance, and $\$ 1,083$ on boat repair and maintenance (Table 8). The average cost of the boat was $\$ 48,909$ (1999 dollars). The lowest boat cost was $\$ 1,815$, and the highest was $\$ 331,923$.

Sixty-nine percent of the slip renters answered that they spent about the same on their last trip compared to other trips taken in the past 
Table 8. Summary of Lake Sidney Lanier Marina slip renters'/users' spending and use profiles, 09/1998 to 08/1999 (spending per party trip).

\begin{tabular}{|c|c|c|c|c|c|c|c|c|}
\hline Spending Categories & Mean & $\begin{array}{l}\text { Std. } \\
\text { Error }\end{array}$ & $\begin{array}{l}\text { Pct. } \\
\text { Error }^{1}\end{array}$ & $\mathrm{~N}$ & Minimum & Maximum & $\begin{array}{l}\text { Pct. } \\
\text { zeroes }\end{array}$ & $\begin{array}{c}\text { Mean } \\
\text { Exc. Zero }\end{array}$ \\
\hline \multicolumn{9}{|c|}{ Spending Information for Last Trip } \\
\hline Gas/oil auto & $\$ 18.83$ & $\$ 2.46$ & $13 \%$ & 204 & $\$ 0$ & $\$ 300$ & $13 \%$ & (\$21.71 \\
\hline Other expenses auto & $\$ 4.10$ & $\$ 1.59$ & $39 \%$ & 206 & $\$ 0$ & $\$ 250$ & $92 \%$ & $\$ 49.65$ \\
\hline Gas/oil boat & $\$ 43.26$ & $\$ 5.06$ & $12 \%$ & 206 & $\$ 0$ & $\$ 400$ & $32 \%$ & $\$ 63.20$ \\
\hline Other expenses boat & $\$ 15.94$ & $\$ 5.33$ & $33 \%$ & 208 & $\$ 0$ & $\$ 600$ & $83 \%$ & $\$ 94.71$ \\
\hline Food/drink restaurants & $\$ 29.08$ & $\$ 4.12$ & $14 \%$ & 204 & $\$ 0$ & $\$ 500$ & $46 \%$ & $\$ 53.45$ \\
\hline Groceries & $\$ 36.85$ & $\$ 4.34$ & $12 \%$ & 206 & $\$ 0$ & $\$ 500$ & $27 \%$ & $\$ 50.61$ \\
\hline Campground fees & $\$ 0.12$ & $\$ 0.12$ & $100 \%$ & 207 & $\$ 0$ & $\$ 25$ & $100 \%$ & $\$ 25.00$ \\
\hline Lodging & $\$ 1.20$ & $\$ 0.86$ & $72 \%$ & 208 & $\$ 0$ & $\$ 150$ & $99 \%$ & $\$ 125.00$ \\
\hline Recreation fees & $\$ 3.29$ & $\$ 1.35$ & $41 \%$ & 207 & $\$ 0$ & $\$ 200$ & $96 \%$ & $\$ 85.00$ \\
\hline Sporting goods & $\$ 4.37$ & $\$ 1.61$ & $37 \%$ & 207 & $\$ 0$ & $\$ 300$ & $91 \%$ & $\$ 47.63$ \\
\hline Other supplies & $\$ 8.56$ & $\$ 2.59$ & $30 \%$ & 208 & $\$ 0$ & $\$ 400$ & $74 \%$ & $\$ 32.96$ \\
\hline Total within 30 miles & $\$ 165.60$ & & & & & & & \\
\hline Expenses for $30+$ miles $^{2}$ & $\$ 21.23$ & $\$ 4.88$ & $23 \%$ & 204 & $\$ 0$ & $\$ 700$ & $70 \%$ & \\
\hline Total trip spending ${ }^{2}$ & $\$ 186.83$ & & & & & & & \\
\hline $\begin{array}{l}\text { Pct of local spending (within } 30 \\
\text { miles) }\end{array}$ & $88.64 \%$ & & & & & & & \\
\hline \multicolumn{9}{|c|}{ Use Information for Last Trip } \\
\hline Nights away from home & 1.23 & 0.17 & $14 \%$ & 208 & 0 & 30 & & \\
\hline Days used boat & 1.85 & 0.10 & $5 \%$ & 208 & 1 & 14 & & \\
\hline Number of people on boat & 3.63 & 0.19 & $5 \%$ & 209 & 1 & 25 & & \\
\hline \multicolumn{9}{|c|}{ Annual Spending for Last Year (09/01/98 - 08/31/99) } \\
\hline Slip rental & (\$2,258.69 & (\$84.91 & $4 \%$ & 201 & $\$ 4450$ & $\$ 6,000$ & & \\
\hline Storage fees & $\$ 91.68$ & $\$ 21.19$ & $23 \%$ & 208 & $\$ 0$ & $\$ 2,400$ & & \\
\hline Insurance payments & $\$ 509.98$ & $\$ 32.75$ & $6 \%$ & 199 & $\$ 0$ & $\$ 3,100$ & & \\
\hline Repair/maintenance & $\$ 1,082.89$ & $\$ 139.58$ & $13 \%$ & 206 & $\$ 0$ & $\$ 15,000$ & & \\
\hline
\end{tabular}




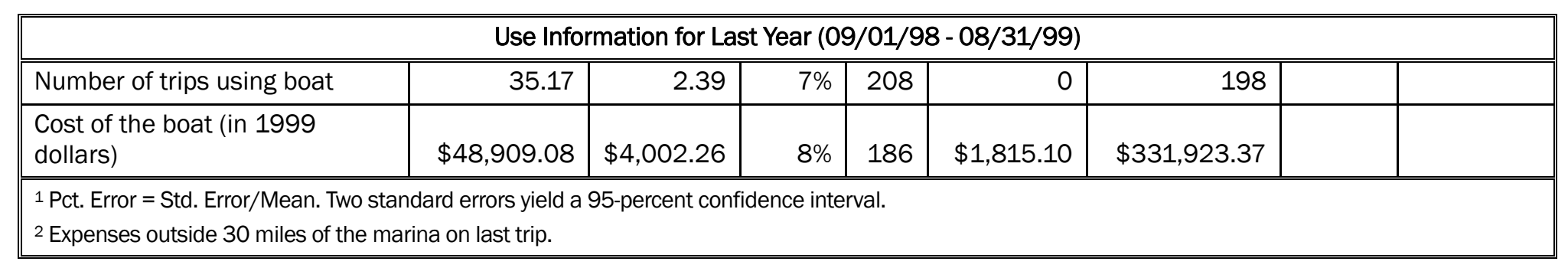


12 months. About 12 percent reported that they spent more than they did on other trips and 19 percent answered they spent less (Figure 14).

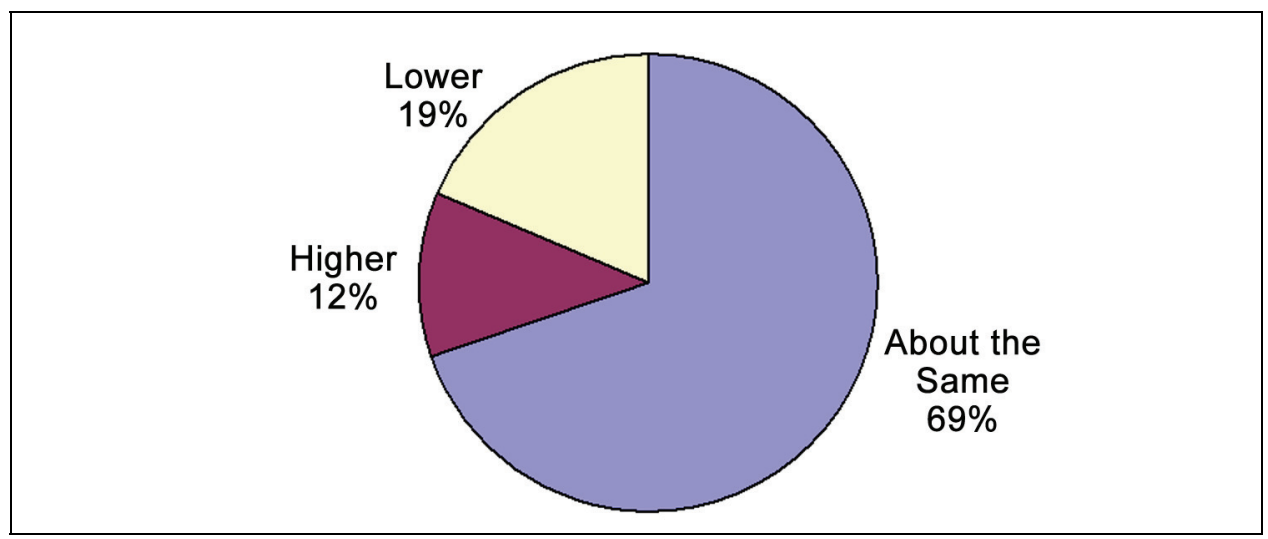

Figure 14. Expenditures by marina slip renters/users on most recent trip compared to similar trips in the last 12 months at Lake Sidney Lanier, $1999(\mathrm{~N}=205)$.

Many of the respondents reported no spending on their last trip in many of the spending categories listed. Categories in which a large percentage (more than 80 percent) of users did not spend money on their last trip were: other expenses on auto (92 percent), other expenses on boat (83 percent), campground fees (100 percent), lodging (99 percent), recreation fees (96 percent), and sporting goods (91 percent). Although the estimates of average trip expenditures in this report are based on the full sample, it is worthwhile to recognize the difference between the average spending of all marina slip users and average spending of just the spenders. The average spending of those who spent something on an item is generally much higher than the average computed from all visitors. For instance, while the average across all slip users was $\$ 1.20$ on lodging per party trip, the two marina slip parties who did spend money on lodging spent an average of $\$ 125$ per party trip (Table 8 ). For estimating total spending of all Lanier marina slip users, it is appropriate to apply the means that include zeros. The means without zeros should not be used to expand the data to population totals, as they only represent spending for specific segments (i.e., slip users who stayed in hotels spent an average of $\$ 125$ on lodging per trip).

\section{Average spending by segment: Day use vs. overnight}

Lanier slip renters were grouped into two segments based on whether or not they stayed overnight away from their permanent home during their 
last trip. The slip renters/users who did not stay away from home (i.e., day users) spent an average of $\$ 78$ for that trip, 91 percent ( $\$ 70)$ of which was spent within 30 miles of the marina slip (Table 9). The average party size was 3.5 people per trip. The slip renters/users who stayed overnight spent an average of 2.3 nights away from home and used the boat for 2.6 days with a party size of 3.8 people per trip. They spent an average of $\$ 274$ for the entire trip, 88 percent (\$241) of which was spent within 30 miles of the marina slip. Day users made an average of 32 boating trips in the previous year, whereas overnight slip users made 38 trips.

Slip renters in the overnight segment owned more expensive boats than day users ( $\$ 64,990$ vs. $\$ 32,970$, respectively). Consequently, they paid more annually in slip rentals fees, insurance payments, and repairs and maintenance than day users. Storage fees for overnight visitors, however, are lower. One possible explanation is that since overnight users have larger boats, and larger boat owners tend to store their boats in the marina all the time instead of purchasing separate storage, their storage fees tend to be less than the fees for those with smaller boats.

For marina slip users, day use and overnight stay segments were nearly even split in the sample (48 percent day users, 52 percent of slip users spent a least one night in the area on their last trip). In terms of total spending in the local region, day use slip users contributed 18 percent, and overnight stay slip users, 82 percent.

\section{Average spending by boat length segments}

Based on the length of the boat, the slip renters were grouped into three segments: boats that were $24 \mathrm{ft}$ and shorter, boats between 25 and $35 \mathrm{ft}$, and boats $36 \mathrm{ft}$ and longer. In general, as boat size increased so did the amount of expenditures, particularly when going from the middle to the longest category. The 24- $\mathrm{ft}$ and smaller segment spent an average of $\$ 103$ per party on the last trip during which about 92 percent (\$95) was spent within 30 miles of the marina slip (Table 10). They stayed an average of just under 0.6 night away from home and used their boat for 1.4 days with a party size of 3.1 people per trip. Slip users in this segment made an average of 30 boating trips the previous year. 
Table 9. Spending and use by length of stay segments, Lake Sidney Lanier Marina slip renter survey, 09/98 to 08/99 (spending per party trip).

\begin{tabular}{|c|c|c|c|c|c|c|c|c|}
\hline \multirow[b]{2}{*}{ Spending Categories } & \multicolumn{4}{|c|}{ Day Users } & \multicolumn{4}{|c|}{ Overnight Users } \\
\hline & Mean & $\begin{array}{l}\text { Std. } \\
\text { Error }\end{array}$ & $\begin{array}{l}\text { Pct. } \\
\text { Error }^{1}\end{array}$ & $\mathrm{~N}$ & Mean & $\begin{array}{l}\text { Std. } \\
\text { Error }\end{array}$ & $\begin{array}{l}\text { Pct. } \\
\text { Error }^{1}\end{array}$ & $\mathrm{~N}$ \\
\hline \multicolumn{9}{|c|}{ 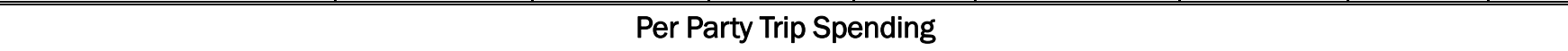 } \\
\hline Gas/oil auto & $\$ 9.00$ & $\$ 1.24$ & $14 \%$ & 96 & $\$ 27.15$ & $\$ 4.42$ & $16 \%$ & 106 \\
\hline Other expenses auto & $\$ 2.39$ & $\$ 1.63$ & $68 \%$ & 96 & $\$ 5.05$ & $\$ 2.61$ & $52 \%$ & 108 \\
\hline Gas/oil boat & $\$ 14.61$ & $\$ 2.20$ & $15 \%$ & 97 & $\$ 65.64$ & $\$ 8.26$ & $13 \%$ & 107 \\
\hline Other expenses boat & $\$ 10.88$ & $\$ 5.61$ & $52 \%$ & 98 & $\$ 16.19$ & $\$ 7.71$ & $48 \%$ & 108 \\
\hline Restaurants & $\$ 13.81$ & $\$ 2.01$ & $15 \%$ & 98 & $\$ 42.95$ & $\$ 7.53$ & $18 \%$ & 105 \\
\hline Groceries & $\$ 11.77$ & $\$ 1.70$ & $14 \%$ & 98 & $\$ 59.52$ & $\$ 7.57$ & $13 \%$ & 107 \\
\hline Campground fees & $\$ 0.00$ & - & - & 97 & $\$ 0.23$ & $\$ 0.23$ & $100 \%$ & 108 \\
\hline Lodging & $\$ 0.00$ & - & - & 98 & $\$ 2.31$ & $\$ 1.66$ & $72 \%$ & 108 \\
\hline Recreation fees & $\$ 0.77$ & $\$ 0.77$ & $100 \%$ & 98 & $\$ 5.65$ & $\$ 2.51$ & $44 \%$ & 107 \\
\hline Sporting goods & $\$ 1.94$ & $\$ 0.83$ & $43 \%$ & 98 & $\$ 6.68$ & $\$ 3.01$ & $45 \%$ & 107 \\
\hline Other supplies & $\$ 5.22$ & $\$ 2.31$ & $44 \%$ & 98 & $\$ 9.89$ & $\$ 4.15$ & $42 \%$ & 108 \\
\hline Total within 30 miles & $\$ 70.37$ & & & & $\$ 241.28$ & & & \\
\hline Expenses $30+$ miles $^{2}$ & $\$ 7.14$ & $\$ 3.23$ & $45 \%$ & 96 & $\$ 32.51$ & $\$ 8.62$ & $27 \%$ & 106 \\
\hline Total trip spending & $\$ 77.51$ & & & & $\$ 273.79$ & & & \\
\hline $\begin{array}{l}\text { Pct. of local spending } \\
\text { (within } 30 \text { miles) }\end{array}$ & $91 \%$ & & & & $88 \%$ & & & \\
\hline \multicolumn{9}{|c|}{ Annual Spending } \\
\hline Slip rental & $\$ 1,868.08$ & $\$ 106.37$ & $6 \%$ & 97 & $\$ 2,637.19$ & $\$ 122.39$ & $5 \%$ & 102 \\
\hline Storage fees & $\$ 112.73$ & $\$ 29.80$ & $26 \%$ & 99 & $\$ 73.93$ & $\$ 30.59$ & $41 \%$ & 107 \\
\hline Insurance payments & $\$ 364.84$ & $\$ 31.97$ & $9 \%$ & 95 & $\$ 649.76$ & $\$ 53.40$ & $8 \%$ & 101 \\
\hline Repair/maintenance & $\$ 942.41$ & $\$ 212.76$ & $23 \%$ & 98 & $\$ 1,195.43$ & $\$ 186.50$ & $16 \%$ & 105 \\
\hline $\begin{array}{l}\text { Cost of the boat (in } \\
1999 \text { dollars) }\end{array}$ & $\$ 32,972.10$ & $\$ 4336.56$ & $13 \%$ & 91 & $\$ 64,992.88$ & $\$ 6446.93$ & $10 \%$ & 92 \\
\hline \multicolumn{9}{|c|}{ Visitor Characteristics } \\
\hline $\begin{array}{l}\text { Total trips using boat } \\
\text { (last year) }\end{array}$ & 32.05 & 3.70 & $12 \%$ & 98 & 38.24 & 3.15 & $8 \%$ & 107 \\
\hline $\begin{array}{l}\text { Nights away from home } \\
\text { (last trip) }\end{array}$ & 0.00 & - & - & 99 & 2.34 & 0.28 & $12 \%$ & 109 \\
\hline $\begin{array}{l}\text { Days used boat (last } \\
\text { trip) }\end{array}$ & 1.00 & - & - & 99 & 2.61 & 0.15 & $6 \%$ & 109 \\
\hline $\begin{array}{l}\text { People on boat (last } \\
\text { trip) }\end{array}$ & 3.48 & 0.30 & $9 \%$ & 98 & 3.81 & 0.25 & $7 \%$ & 109 \\
\hline
\end{tabular}


Table 10. Spending and use by boat length segments, Lake Sidney Lanier Marina slip renter survey, 09/98 to 08/99 (spending per party trip).

\begin{tabular}{|c|c|c|c|c|c|c|c|c|c|c|c|c|}
\hline \multirow[b]{2}{*}{ Spending Categories } & \multicolumn{4}{|c|}{ 24' and Smaller } & \multicolumn{4}{|c|}{$25^{\prime}$ to $35^{\prime}$} & \multicolumn{4}{|c|}{36 and Larger } \\
\hline & Mean & $\begin{array}{l}\text { Std. } \\
\text { Error }\end{array}$ & $\begin{array}{l}\text { Pct. } \\
\text { Error }{ }^{1}\end{array}$ & $\mathrm{~N}$ & Mean & $\begin{array}{l}\text { Std. } \\
\text { Error }\end{array}$ & $\begin{array}{l}\text { Pct. } \\
\text { Error }{ }^{1}\end{array}$ & $\mathrm{~N}$ & Mean & $\begin{array}{l}\text { Std. } \\
\text { Error }\end{array}$ & $\begin{array}{l}\text { Pct. } \\
\text { Error }{ }^{1}\end{array}$ & $\mathrm{~N}$ \\
\hline \multicolumn{13}{|c|}{ Per Party Trip Spending } \\
\hline Gas/oil auto & $\$ 14.88$ & $\$ 2.64$ & $18 \%$ & 57 & $\$ 17.99$ & $\$ 4.00$ & $22 \%$ & 99 & $\$ 25.27$ & $\$ 5.57$ & $22 \%$ & 48 \\
\hline Other expenses auto & $\$ 1.65$ & $\$ 0.89$ & $54 \%$ & 57 & $\$ 6.03$ & $\$ 3.12$ & $52 \%$ & 100 & $\$ 3.00$ & $\$ 1.77$ & $59 \%$ & 49 \\
\hline Gas/oil boat & $\$ 15.52$ & $\$ 3.00$ & $19 \%$ & 58 & $\$ 32.10$ & $\$ 4.42$ & $14 \%$ & 99 & $\$ 98.63$ & $\$ 16.66$ & $17 \%$ & 49 \\
\hline Other expenses boat & $\$ 11.26$ & $\$ 6.22$ & $55 \%$ & 58 & $\$ 14.79$ & $\$ 7.77$ & $53 \%$ & 101 & $\$ 23.84$ & $\$ 14.27$ & $60 \%$ & 49 \\
\hline Restaurants & $\$ 18.79$ & $\$ 3.72$ & $20 \%$ & 58 & $\$ 30.20$ & $\$ 5.55$ & $18 \%$ & 100 & $\$ 39.63$ & $\$ 12.81$ & $32 \%$ & 46 \\
\hline Groceries & $\$ 20.69$ & $\$ 3.86$ & $19 \%$ & 58 & $\$ 26.52$ & $\$ 3.80$ & $14 \%$ & 100 & $\$ 77.92$ & $\$ 14.84$ & $19 \%$ & 48 \\
\hline Campground fees & $\$ 0.43$ & $\$ 0.43$ & $100 \%$ & 58 & $\$ 0.00$ & $\$ 0.00$ & - & 100 & $\$ 0.00$ & $\$ 0.00$ & - & 49 \\
\hline Lodging & $\$ 2.59$ & $\$ 2.59$ & $100 \%$ & 58 & $\$ 0.00$ & $\$ 0.00$ & - & 101 & $\$ 2.04$ & $\$ 2.04$ & $100 \%$ & 49 \\
\hline Recreation fees & $\$ 1.29$ & $\$ 1.29$ & $100 \%$ & 58 & $\$ 3.22$ & $\$ 1.65$ & $51 \%$ & 101 & $\$ 5.83$ & $\$ 4.45$ & $76 \%$ & 48 \\
\hline Sporting goods & $\$ 2.24$ & $\$ 1.21$ & $54 \%$ & 58 & $\$ 6.60$ & $\$ 3.19$ & $48 \%$ & 100 & $\$ 2.35$ & $\$ 1.26$ & $54 \%$ & 49 \\
\hline Other supplies & $\$ 5.62$ & $\$ 3.48$ & $62 \%$ & 58 & $\$ 8.42$ & $\$ 4.09$ & $49 \%$ & 101 & $\$ 12.33$ & $\$ 5.74$ & $47 \%$ & 49 \\
\hline Total within $\mathbf{3 0}$ miles & $\$ 94.96$ & & & & $\$ 145.87$ & & & & $\$ 290.83$ & & & \\
\hline Expenses 30+ miles $^{2}$ & $\$ 8.37$ & $\$ 3.00$ & $36 \%$ & 57 & $\$ 15.02$ & $\$ 4.66$ & $31 \%$ & 98 & $\$ 48.61$ & $\$ 17.26$ & $36 \%$ & 49 \\
\hline Total trip spending & $\$ 103.33$ & & & & $\$ 160.89$ & & & & $\$ 339.45$ & & & \\
\hline $\begin{array}{l}\text { Pct. of local spending } \\
\text { (within } 30 \text { miles) }\end{array}$ & $92 \%$ & & & & $91 \%$ & & & & $86 \%$ & & & \\
\hline \multicolumn{13}{|c|}{ Annual Spending } \\
\hline Slip rental & $\$ 1,291.05$ & $\$ 85.20$ & $7 \%$ & 55 & $\$ 2,191.71$ & $\$ 92.87$ & $4 \%$ & 101 & $\$ 3,591.69$ & $\$ 157.75$ & $4 \%$ & 45 \\
\hline Storage fees & $\$ 75.69$ & $\$ 23.62$ & $31 \%$ & 58 & $\$ 137.65$ & $\$ 40.39$ & $29 \%$ & 102 & $\$ 13.33$ & $\$ 8.13$ & $61 \%$ & 48 \\
\hline Insurance payments & $\$ 243.44$ & $\$ 30.06$ & $12 \%$ & 55 & $\$ 461.16$ & $\$ 29.92$ & $6 \%$ & 99 & $\$ 943.16$ & $\$ 96.16$ & $10 \%$ & 45 \\
\hline
\end{tabular}




\begin{tabular}{|c|c|c|c|c|c|c|c|c|c|c|c|c|}
\hline Repair/maintenance & $\$ 482.98$ & $\$ 110.79$ & $23 \%$ & 57 & \$1,059.67 & $\$ 202.25$ & $19 \%$ & 103 & \$1,878.26 & $\$ 383.29$ & $20 \%$ & 46 \\
\hline $\begin{array}{l}\text { Cost of the boat (in } 1999 \\
\text { dollars) }\end{array}$ & $\$ 16,665.08$ & $\$ 3100.64$ & $19 \%$ & 55 & $\$ 45,371.43$ & $\$ 3908.57$ & $9 \%$ & 94 & $\$ 105,826.91$ & $\$ 12581.65$ & $12 \%$ & 37 \\
\hline \multicolumn{13}{|c|}{ Visitor Characteristics } \\
\hline $\begin{array}{l}\text { Total trips using boat (last } \\
\text { year) }\end{array}$ & 29.98 & 4.33 & $14 \%$ & 58 & 34.24 & 3.33 & $10 \%$ & 102 & 43.42 & 5.33 & $12 \%$ & 48 \\
\hline $\begin{array}{l}\text { Nights away from home } \\
\text { (last trip) }\end{array}$ & 0.60 & 0.14 & $24 \%$ & 58 & 0.94 & 0.12 & $13 \%$ & 101 & 2.55 & 0.61 & $24 \%$ & 49 \\
\hline Days used boat (last trip) & 1.38 & 0.10 & $7 \%$ & 58 & 1.68 & 0.10 & $6 \%$ & 101 & 2.73 & 0.30 & $11 \%$ & 49 \\
\hline People on boat (last trip) & 3.14 & 0.24 & $8 \%$ & 58 & 3.60 & 0.29 & $8 \%$ & 101 & 4.26 & 0.47 & $11 \%$ & 50 \\
\hline
\end{tabular}


The 25- to 35 - $\mathrm{ft}$ boat segment spent an average of $\$ 161$ per party on the last trip ( $\$ 146$ within 30 miles of the marina slip). They stayed an average of nearly one night away from home, used their boat for 1.7 days with a party size of 3.6 people per trip. They made an average of 34 boating trips the previous year. Renters/users in the largest boat size segment averaged more than \$339 per party on goods and services during their last trip (\$291 of the money was spent locally). They stayed away from home an average of 2.6 nights and used the boat for 2.7 days per trip. The average party size for this group was 4.3 people per trip. Renters/users in this segment made an average of 43 boating trips the previous year.

Except for storage fees (for reason explained above), the larger the boat, the more slip renters spent on annual expenses. Slip rentals ranged from $\$ 1,300$ for boats $24 \mathrm{ft}$ and shorter to $\$ 3,600$ for boats $36 \mathrm{ft}$ and longer. The cost of the boat ranged from $\$ 17,000$ for the $24-\mathrm{ft}$ and smaller segment to $\$ 106,000$ for the 36 -ft and larger segment, while the insurance payments ranged from $\$ 243$ to $\$ 943$ a year across the three segments. Boat repair and maintenance costs similarly grew from $\$ 483$ to $\$ 1,878$ per year as boat size increased (Table 10).

Half the sample had medium-sized boats ( 25 to $35 \mathrm{ft}$ ), while a quarter were small (under $25 \mathrm{ft}$ ) and a quarter were large (above $35 \mathrm{ft}$ ). Slip users with large boats contributed 48 percent of total spending locally, slip users with medium-sized boats, 39 percent, and those with small boats, 13 percent.

\section{Total spending}

The figures in Table 11 were derived from secondary data sources, the Natural Resource System Management (NRMS) (USACE 2006c) and from survey data for Lanier (e.g., average number of trips per boat last year). The 96 percent occupancy rate for marina slips came from the 1999 NRMS database. Based on the assumption that there was one boat for each occupied slip, the total number of 5,642 boats used by slip users at Lake Sidney Lanier was computed by multiplying the occupancy rate ( 96 percent) by the total number of wet slips (5,877 from NRMS). Lanier slip users took 198,417 boating party trips in 1999 (7.6 percent of total recreation use ${ }^{1}$ ) and purchased 198 new boats (Table 11).

\footnotetext{
17.7 million recreation visits in 1999 from Table 1 divided by an average party size of 3.0 from Propst et al. (1998) equals 2.6 total million party trips; 198,417 is 7.6 percent of 2.6 million party trips.
} 
Table 11. Total annual use figures for marina slip renter survey at Lake Sidney Lanier (1999).

\begin{tabular}{|l|l|l||}
\hline Category & Total Use & Computation Procedures \\
\hline \hline Occupancy rate & $96 \%$ & 1 From NRMS (1999) \\
\hline \hline Number of slips & 5,877 & 1 From NRMS (1999) \\
\hline Number of boats & 5,642 & $\begin{array}{l}\text { Number of slips times occupancy } \\
\text { rate }\end{array}$ \\
\hline Number of party trips & 198,417 & $\begin{array}{l}\text { Average party trips (from Table 3) } \\
\text { times total number of boats (Ref- } \\
\text { erence Foreword) }\end{array}$ \\
\hline Percent of new boats purchased last year & $3.51 \%$ & $\begin{array}{l}\text { Computed from survey results, } \\
\text { using the 3-year average (1997 to } \\
1999)\end{array}$ \\
\hline Number of new boats purchased last year & 198 & $\begin{array}{l}\text { Total boats times percent of new } \\
\text { boats purchased last year }\end{array}$ \\
\hline \hline
\end{tabular}

Local and total trip-related spending (Tables 12 and 13) is calculated by multiplying the number of party-trips in Table $11(198,417)$ by the trip spending averages in Table 8 . Total spending on boats and fixed, annual goods and services (Table 14) is estimated by multiplying the number of boats in Table $11(5,642)$ by the annual expenditures on boats, slip rental fees, boat repairs and maintenance, and storage in Table 8. Total spending on insurance is estimated by multiplying the number of boats $(5,642)$ by the proportion of local boat owners who purchased boat insurance and their average insurance payment. Total spending on purchasing new boats is estimated by multiplying the number of new boats purchased last year (198) by the proportion of local slip renters who bought new boats and the average local new boat cost for three years: 1997-1999.

A recreation visit, as reported in the NRMS database, is one person entering a Corps project. Spending depends on how long a person stays in the local region rather than how many times they enter the project or how much time they spend in recreation activities while there. Recreation visits are therefore converted to party trips ${ }^{1}$ in the region before applying

\footnotetext{
1 See Table 11 for the conversion steps. A party is a travel group staying in the area (within 30 miles of the marina). The travel group is usually all individuals in the same vehicle or on the same boat or staying in the same room or campsite. During the interviews, slip renters were asked to report expenditures for their entire party for the last trip. Thus, the units for expenditures are party trips. Converting visits to party trips assures that the units are the same in the multiplication steps that lead to estimates of total expenditures (visits in party trips times expenditures in party trips).
} 
spending averages. This procedure avoids double-counting the spending of marina slip users who may enter the project multiple times on the same day and also takes into account additional days a slip user may spend in the area outside the project.

The estimated trip spending for all Lanier marina slip users in 1999 was $\$ 33$ million spent within the local region (Table 12). If trip spending outside 30 miles is included, the total rises to $\$ 37$ million (Table 13). Only trip spending within 30 miles of the marina slip (\$33 million) should be included when conducting economic impact analysis at the project level (multi-county region).

Table 12. Total trip spending in local area ${ }^{1}$ by Lake Sidney Lanier Marina slip renters/users (1999).

\begin{tabular}{|l|l|}
\hline Spending Category & Spending (\$MM) \\
\hline \hline Gas/oil auto & $\$ 3.74$ \\
\hline Other expenses auto & $\$ 0.81$ \\
\hline Gas/oil boat & $\$ 8.58$ \\
\hline Other expenses boat & $\$ 3.16$ \\
\hline Restaurants & $\$ 5.77$ \\
\hline Groceries & $\$ 7.31$ \\
\hline Campground fees & $\$ 0.02$ \\
\hline Lodging & $\$ 0.24$ \\
\hline Recreation fees & $\$ 0.65$ \\
\hline Sporting goods & $\$ 0.87$ \\
\hline Other supplies & $\$ 1.70$ \\
\hline Total trip spending & $\$ 32.86$ \\
\hline \hline 1 Local trip spending equals spending within 30 miles of the slip. \\
\hline
\end{tabular}


Table 13. Total trip spending ${ }^{1}$ by Lake Sidney Lanier Marina slip renters/users (1999).

\begin{tabular}{|l|l||}
\hline Spending Category & Spending (\$MM) ${ }^{2}$ \\
\hline \hline Gas/oil auto & $\$ 4.48$ \\
\hline Other expenses auto & $\$ 0.98$ \\
\hline Gas/oil boat & $\$ 8.58$ \\
\hline Other expenses boat & $\$ 3.16$ \\
\hline Restaurants & $\$ 6.92$ \\
\hline Groceries & $\$ 8.77$ \\
\hline Campground fees & $\$ 0.03$ \\
\hline Lodging & $\$ 0.29$ \\
\hline Recreation fees & $\$ 0.78$ \\
\hline Sporting goods & $\$ 1.04$ \\
\hline Other supplies & $\$ 2.04$ \\
\hline Total trip spending & $\$ 37.07$ \\
\hline \hline $\begin{array}{l}\text { 1 Total trip spending equals spending within and outside } 30 \text { miles of the slip. } \\
\text { 2 Slip renters were asked to report trip spending outside } 30 \text { miles of the marina slip as one total } \\
\text { amount, not broken down by item as this table shows. This aggregate spending figure was then } \\
\text { proportionally distributed into all but two categories based on the spending proportions within } \\
\text { 30 miles. Proportional allocations were not made to the "gas/oil boat" and "other expenses boat" } \\
\text { categories. It was assumed that, for these two categories, there were no boating expenditures } \\
\text { outside 30 miles of the marina slip. }\end{array}$ \\
\hline
\end{tabular}

Fixed, annual goods and services related to boating activities in this study were new boats, slip rental fees, storage fees, insurance, and repairs and maintenance. Lanier's marina slip renters spent \$31 million (1999 dollars) on boating-related annual goods and services (Table 14). Forty-one percent of the money was spent on slip rental fees ( $\$ 13$ million), followed by purchases of new boats ( $\$ 10$ million), repairs/maintenance ( $\$ 6$ million), insurance ( $\$ 2$ million), and storage fees $(\$ 520,000)$.

Table 14. Total spending on fixed, annual goods and services by marina slip renters at Lake Sidney Lanier (1999).

\begin{tabular}{||l|l||}
\hline Spending Category & Spending (\$MM) \\
\hline \hline Slip rentals & $\$ 12.74$ \\
\hline Storage fees & $\$ 0.52$ \\
\hline $\begin{array}{l}\text { Insurance payments (include only payments from slip rent- } \\
\text { ers who lived within 30 miles of the marina) }\end{array}$ & $\$ 1.66$ \\
\hline Repair/maintenance & $\$ 6.11$ \\
\hline Purchases of new boats (within 30 miles) & $\$ 10.00$ \\
\hline Total durable goods spending & $\$ 31.04$ \\
\hline
\end{tabular}




\section{Economic impacts of slip user spending}

\section{9 impacts}

The \$33 million in trip-related spending from Table 12 had a direct economic impact on the region of $\$ 19.6$ million in direct sales, $\$ 7.7$ million in personal income (wages and salaries), and supported 328 jobs in the region (Table 15). The eating and drinking (restaurants and bars) sector received the largest amount of direct sales ( $\$ 5.8$ million), followed by retail trade (\$5.2 million).

Direct effects are less than total spending, as only the retail and wholesale margins on visitor purchases of goods accrue to the local economy. The local region surrounding Lake Sidney Lanier captures 60 percent of slip user spending. Forty percent leaks out of the local economy to cover the costs of imported goods bought by visitors. ${ }^{1}$

The sales multiplier ${ }^{2}$ for the region is 1.60 , meaning that sixty cents in additional sales are generated through secondary effects for every dollar of direct sales. However, secondary effects generate an additional 128 jobs, for a total of 456 direct and secondary jobs (Table 15). Likewise, secondary effects generate an additional \$4.4 million in personal income and $\$ 7.2$ million in value added (personal income + proprietor's income + indirect business tax). Roughly 10 direct jobs are supported by each million dollars in total slip user spending. Including multiplier effects, each million dollars in total slip user spending supports about 14 jobs.

The \$31 million in spending on new boats, slip rental fees, storage fees, insurance, and repairs/maintenance from Table 14 had a direct economic impact on the region of $\$ 22.3$ million in direct sales, $\$ 5.9$ million in personal income (wages and salaries), and supported 143 direct jobs in the region (Table 16). The services sector received the largest amount of direct sales ( $\$ 14.5$ million), followed by manufacturing (\$5 million).

\footnotetext{
1 For example, if a visitor buys $\$ 50$ worth of clothing that is not manufactured in the local region, only the local margins (retail and locally operated wholesale and transportation), say $\$ 30$, will be captured by the local economy as direct sales. The remaining $\$ 20$ will leak immediately outside the local economy to cover the producer price (or price of good at the factory), and non-local margins (wholesale and transportation).

2 Multipliers for the 16-county region are from a 2000 input-output model estimated with the IMPLAN system.
} 
Table 15. Regional economic impacts of Lake Sidney Lanier Marina slip renters'/users' trip spending (1999, for trip spending within 30 miles only).

\begin{tabular}{|c|c|c|c|c|}
\hline \multicolumn{5}{|c|}{$\begin{array}{c}\text { SUMMARY RESULTS TABLE } \\
\text { IMPACTS ON LOCAL ECONOMY }\end{array}$} \\
\hline \multicolumn{2}{|l|}{ Economic Measure } & Direct & Multiplier & Total \\
\hline \multicolumn{2}{|l|}{ Output/sales (\$MM) } & $\$ 19.60$ & 1.60 & $\$ 31.34$ \\
\hline \multicolumn{2}{|l|}{ Total income (\$MM) } & $\$ 7.72$ & 0.62 & $\$ 12.13$ \\
\hline \multicolumn{2}{|l|}{ Total value added (\$MM) } & $\$ 11.73$ & 0.97 & $\$ 18.95$ \\
\hline \multicolumn{2}{|l|}{ Jobs } & 328.49 & 23.29 & 456.48 \\
\hline \multicolumn{3}{|c|}{ Total visitor spending (\$MM) } & \multicolumn{2}{|l|}{32.86} \\
\hline \multicolumn{3}{|l|}{ Capture rate } & \multicolumn{2}{|l|}{$60 \%$} \\
\hline \multicolumn{3}{|c|}{ Effective spending multiplier } & \multicolumn{2}{|l|}{0.95} \\
\hline \multicolumn{5}{|c|}{ Direct Effects } \\
\hline Sector & Sales (\$MM) & Income (\$MM) & $\begin{array}{l}\text { Value Added } \\
\text { (\$MM) }\end{array}$ & Jobs \\
\hline Lodging & $\$ 0.26$ & $\$ 0.11$ & $\$ 0.17$ & 2.79 \\
\hline Eat and drink & $\$ 5.77$ & $\$ 2.23$ & $\$ 3.15$ & 154.95 \\
\hline $\begin{array}{l}\text { Amusement and recrea- } \\
\text { tion }\end{array}$ & $\$ 0.42$ & $\$ 0.18$ & $\$ 0.26$ & 15.80 \\
\hline Retail & $\$ 5.19$ & $\$ 2.52$ & $\$ 4.11$ & 93.90 \\
\hline Wholesale & $\$ 3.14$ & $\$ 1.32$ & $\$ 2.18$ & 22.42 \\
\hline Other services & $\$ 1.54$ & $\$ 0.47$ & $\$ 0.70$ & 14.46 \\
\hline Groceries & $\$ 0.91$ & $\$ 0.16$ & $\$ 0.29$ & 4.55 \\
\hline Sporting goods & $\$ 0.03$ & $\$ 0.00$ & $\$ 0.01$ & 0.10 \\
\hline Other manufacturing & $\$ 2.22$ & $\$ 0.69$ & $\$ 0.81$ & 18.90 \\
\hline Government & $\$ 0.12$ & $\$ 0.03$ & $\$ 0.04$ & 0.62 \\
\hline Total & $\$ 19.60$ & $\$ 7.72$ & $\$ 11.73$ & 328.49 \\
\hline \multicolumn{5}{|c|}{ Total Effects } \\
\hline Sector & Sales (\$MM) & Income (\$MM) & $\begin{array}{l}\text { Value Added } \\
\text { (\$MM) }\end{array}$ & Jobs \\
\hline Lodging & $\$ 0.43$ & $\$ 0.18$ & $\$ 0.28$ & 4.65 \\
\hline Eat and drink & $\$ 6.17$ & $\$ 2.39$ & $\$ 3.37$ & 165.69 \\
\hline $\begin{array}{l}\text { Amusement and recrea- } \\
\text { tion }\end{array}$ & $\$ 0.63$ & $\$ 0.27$ & $\$ 0.37$ & 19.83 \\
\hline Retail & $\$ 6.08$ & $\$ 2.96$ & $\$ 4.83$ & 112.70 \\
\hline Wholesale & $\$ 4.31$ & $\$ 1.81$ & $\$ 2.99$ & 30.68 \\
\hline Other services & $\$ 8.24$ & $\$ 2.96$ & $\$ 5.05$ & 81.50 \\
\hline Groceries & $\$ 1.36$ & $\$ 0.25$ & $\$ 0.42$ & 6.82 \\
\hline Sporting goods & $\$ 0.03$ & $\$ 0.01$ & $\$ 0.01$ & 0.10 \\
\hline Other manufacturing & $\$ 3.75$ & $\$ 1.19$ & $\$ 1.47$ & 31.20 \\
\hline Government & $\$ 0.33$ & $\$ 0.13$ & $\$ 0.16$ & 3.31 \\
\hline Total & $\$ 31.34$ & $\$ 12.13$ & $\$ 18.95$ & 456.48 \\
\hline
\end{tabular}


Table 16. Regional economic impacts of Lake Sidney Lanier Marina Slip renters' durable goods and annual spending (1999)

\begin{tabular}{|c|c|c|c|c|}
\hline \multicolumn{5}{|c|}{$\begin{array}{l}\text { SUMMARY RESULTS TABLE } \\
\text { IMPACTS ON LOCAL ECONOMY }\end{array}$} \\
\hline \multicolumn{2}{|l|}{ Economic Measure } & Direct & Multiplier & Total \\
\hline \multicolumn{2}{|l|}{ Output/sales (\$MM) } & $\$ 22.39$ & 1.61 & $\$ 36.07$ \\
\hline \multicolumn{2}{|l|}{ Total income (\$MM) } & $\$ 5.90$ & 0.51 & $\$ 11.45$ \\
\hline \multicolumn{2}{|l|}{ Total value added (\$MM) } & $\$ 8.65$ & 0.76 & $\$ 17.01$ \\
\hline \multicolumn{2}{|l|}{ Jobs } & 143.48 & 13.23 & 296.37 \\
\hline \multicolumn{3}{|c|}{ Total visitor spending (\$MM) } & \multicolumn{2}{|l|}{31.04} \\
\hline \multicolumn{3}{|c|}{ Capture rate } & \multicolumn{2}{|l|}{$72 \%$} \\
\hline \multicolumn{3}{|c|}{ Effective spending multiplier } & \multicolumn{2}{|l|}{1.16} \\
\hline \multicolumn{5}{|c|}{ Direct Effects } \\
\hline Sector & Sales (\$MM) & Income (\$MM) & $\begin{array}{l}\text { Value Added } \\
\text { (\$MM) }\end{array}$ & Jobs \\
\hline Lodging & $\$$ & \$- & \$- & - \\
\hline Eat and drink & $\$-$ & $\$-$ & $\$-$ & - \\
\hline Amusement and recreation & $\$-$ & $\$-$ & $\$-$ & - \\
\hline Retail & $\$ 2.62$ & $\$ 1.18$ & $\$ 1.97$ & 30.27 \\
\hline Wholesale & $\$ 0.35$ & $\$ 0.15$ & $\$ 0.24$ & 2.48 \\
\hline Other services & $\$ 14.45$ & $\$ 2.99$ & $\$ 4.58$ & 66.63 \\
\hline Groceries & $\$-$ & $\$-$ & $\$-$ & - \\
\hline Sporting goods & $\$-$ & $\$-$ & $\$-$ & - \\
\hline Other manufacturing & $\$ 4.97$ & $\$ 1.58$ & $\$ 1.85$ & 44.11 \\
\hline Government & $\$ 0.01$ & $\$ 0.00$ & $\$ 0.00$ & 0.00 \\
\hline Total & $\$ 22.39$ & $\$ 5.90$ & $\$ 8.65$ & 143.48 \\
\hline \multicolumn{5}{|c|}{ Total Effects } \\
\hline Sector & Sales (\$MM) & Income (\$MM) & $\begin{array}{l}\text { Value Added } \\
\text { (\$MM) }\end{array}$ & Jobs \\
\hline Lodging & $\$ 0.15$ & $\$ 0.07$ & $\$ 0.10$ & 1.65 \\
\hline Eat and drink & $\$ 0.35$ & $\$ 0.14$ & $\$ 0.19$ & 9.40 \\
\hline Amusement and recreation & $\$ 0.14$ & $\$ 0.06$ & $\$ 0.08$ & 3.31 \\
\hline Retail & $\$ 3.45$ & $\$ 1.58$ & $\$ 2.64$ & 47.83 \\
\hline Wholesale & $\$ 1.32$ & $\$ 0.56$ & $\$ 0.92$ & 9.40 \\
\hline Other services & $\$ 23.66$ & $\$ 6.83$ & $\$ 10.39$ & 165.38 \\
\hline Groceries & $\$ 0.15$ & $\$ 0.03$ & $\$ 0.04$ & 0.72 \\
\hline Sporting goods & $\$ 0.01$ & $\$ 0.00$ & $\$ 0.00$ & 0.00 \\
\hline Other manufacturing & $\$ 6.55$ & $\$ 2.08$ & $\$ 2.51$ & 55.78 \\
\hline Government & $\$ 0.28$ & $\$ 0.11$ & $\$ 0.13$ & 2.89 \\
\hline Total & $\$ 36.07$ & $\$ 11.45$ & $\$ 17.01$ & 296.37 \\
\hline
\end{tabular}


Direct effects only accrue to the industries where slip renter spending is directly received. For example, since no money is spent in the Lodging sector from slip renter annual or durable goods spending, that cell is blank in the top sector of Table 16 (Direct Effects). However, other companies receiving direct payments, e.g. insurance companies may hire employees who live in the region and spend money in the local Lodging sector. Since this is a multiplier (secondary) effect upon the Lodging sector, some amount of sales appears in the Lodging cell in the total effects sector of Table 16.

The local region surrounding Lake Sidney Lanier captures 72 percent of slip renter spending on new boats and annual services. Twenty-eight percent leaks out of the local economy to cover the costs of imported boats and services bought by visitors.

The sales multiplier for the region is 1.61, meaning that an additional 61 cents in sales are generated through secondary effects for every dollar of direct sales. Secondary effects generate an additional 153 jobs, for a total of 296 direct and secondary jobs (Table 16). Likewise, secondary effects generate an additional $\$ 5.6$ million in personal income and $\$ 8.4$ million in value added (personal income + proprietor's income + indirect business tax). Roughly 5 direct jobs are supported by each million dollars in total slip renter spending for new boats and annual services. Including multiplier effects, each million dollars in total slip renter spending supports about 10 jobs.

\section{Value of 1999 impacts in 2004 dollars}

The 1999 economic impacts reported above were adjusted to 2004 impacts by multiplying 1999 figures by an average consumer price index of 1.21 (U.S. Department of Labor 2006). The results are presented in Table 17.

In 2004 dollars, total marina slip user trip spending locally of $\$ 39.8$ million resulted in $\$ 9.3$ million in the region in personal income and $\$ 14.2$ million in value added (personal income + proprietor's income + indirect business tax). With secondary (multiplier) effects, total impacts locally were $\$ 14.7$ million in personal income and $\$ 22.9$ million in value added. There is no change to the number of direct jobs (472) in going from Tables 15 and 16 to Table 17. This is because no new expenditures by slip users are being estimated in Table 17. Instead, expenditures from the 1999 
survey are being inflated to 2004 dollars. Since there are no new expenditures, there are no additional jobs being created in 2004.

Table 17. Regional economic impacts of Lake Sidney Lanier Marina slip renters'/users' trip and renters' annual spending (in 2004 dollars, for spending within 30 miles only).

\begin{tabular}{||l|c|c|c|c||}
\hline Economic Measure & \multicolumn{2}{|c|}{$\begin{array}{c}\text { Trip Spending } \\
\text { (within 30 miles) }\end{array}$} & $\begin{array}{c}\text { Durable Goods and Other Annual } \\
\text { Costs Spent Locally }\end{array}$ \\
\hline \hline Total spending (\$MM) & \multicolumn{2}{|c|}{$\$ 39.76$} & \multicolumn{2}{c||}{$\$ 37.56$} \\
\hline \hline Output/sales (\$MM) & Direct Effects & Total Effects & Direct Effects & Total Effects \\
\hline Total income $(\$ M M)$ & $\$ 23.72$ & $\$ 37.92$ & $\$ 27.10$ & $\$ 43.64$ \\
\hline Total value added (\$MM) & $\$ 9.34$ & $\$ 14.68$ & $\$ 7.14$ & $\$ 13.85$ \\
\hline \hline $\begin{array}{l}\text { Note: Spending and economic effects in this table are in 2004 dollars, as opposed to the } 1999 \text { dollars reported } \\
\text { elsewhere in this report }\end{array}$
\end{tabular}

After converting annual goods and services to 2004 dollars, the results are $\$ 37.56$ million marina slip renter spending on new boats, storage fees, insurance, and repairs/maintenance. The impacts of annual spending include $\$ 7.1$ million in personal income and $\$ 10.5$ million in value added. With secondary (multiplier) effects, total impacts locally were \$13.9 million in personal income and \$20.6 million in value added. 


\section{Results - Private Dock Owners}

As with marina slip renters, results for private dock owners are provided in four parts: respondent profiles (including socio-economic characteristics); recreation trip characteristics (amount of boat use, recreation activities, and boat type); per-trip and annual spending; and the economic impacts of dock owners'/users' spending on the local region surrounding Lake Sidney Lanier.

\section{Respondent profiles}

The general characteristics of private dock owners as individuals and by households at Lake Sidney Lanier are shown in Figures 15 to 24. In general, the private dock owners were mostly white males with high education and income. Among the respondents, 75 percent were male and more than 75 percent were aged 46 and above (Figures 15 and 16). The average age was 56 (range $=26$ to 86 years old). The most frequent age (mode) was 50 . Eighty-three percent of the dock owners had at least some college education and 66 percent had college degrees or more. In fact, 15 percent of Lanier's private dock owners held graduate degrees (Figure 17). Almost all of the renters interviewed were white (Figure 18). All private dock slips have registered boats; surveys may or may not have been conducted with the registered boat owner. Ninety-three percent of the renters were also the registered boat owner at the time of the interview (Figure 19).

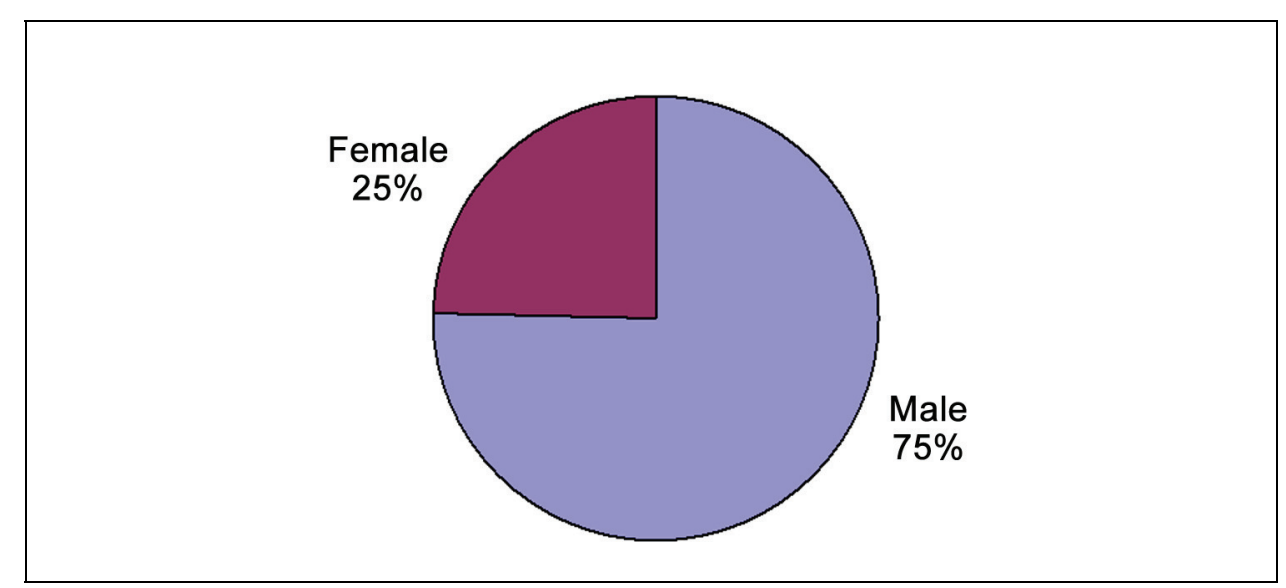

Figure 15. Gender of private dock owners at Lake Sidney Lanier, 1999 ( $N=338$ ). 


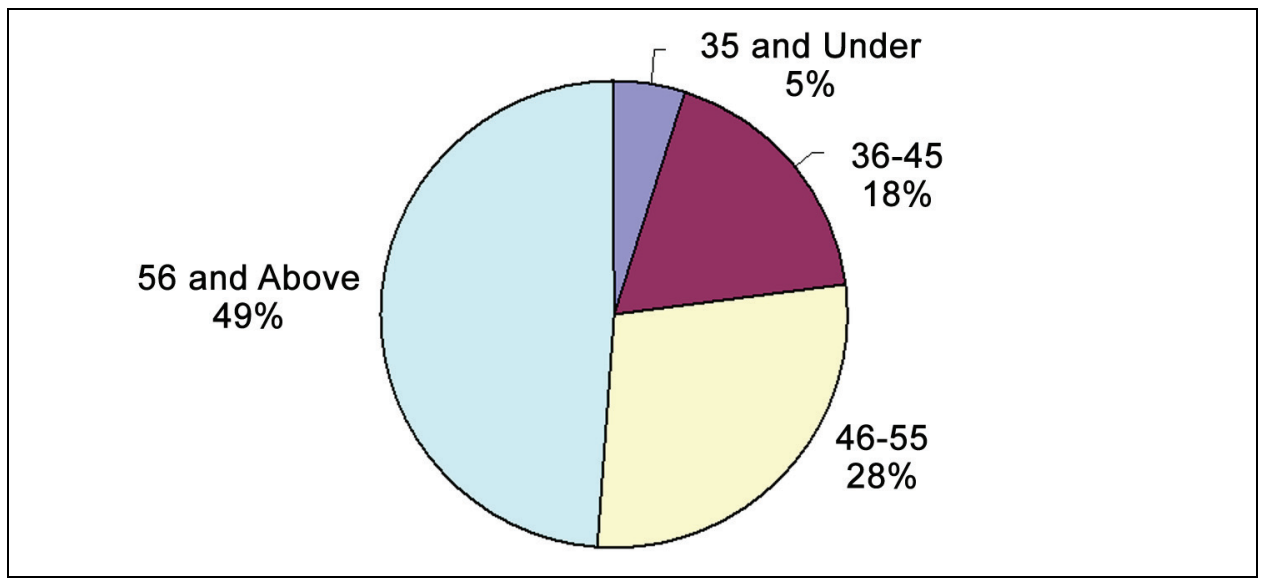

Figure 16. Age of private dock owners at Lake Sidney Lanier, $1999(\mathrm{~N}=332)$.

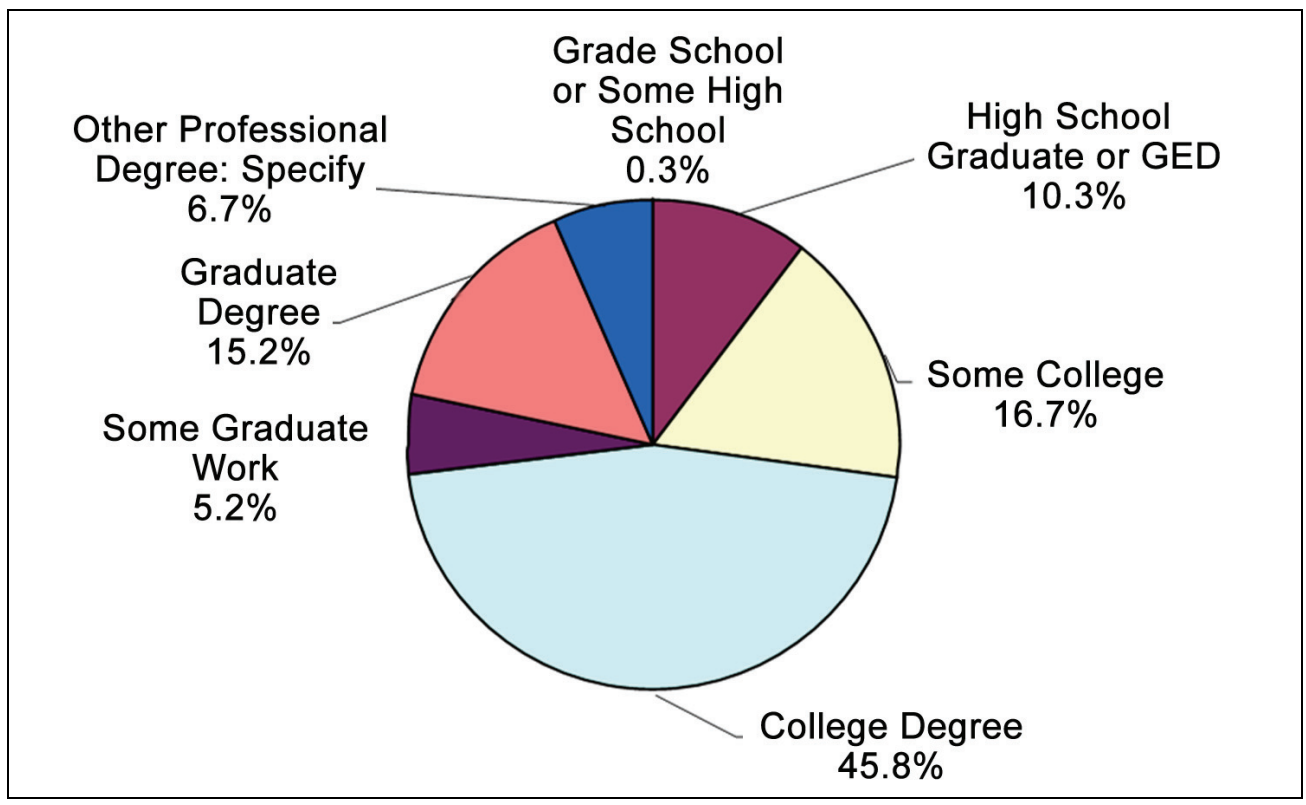

Figure 17. Education of private dock owners at Lake Sidney Lanier, $1999(\mathrm{~N}=330)$.

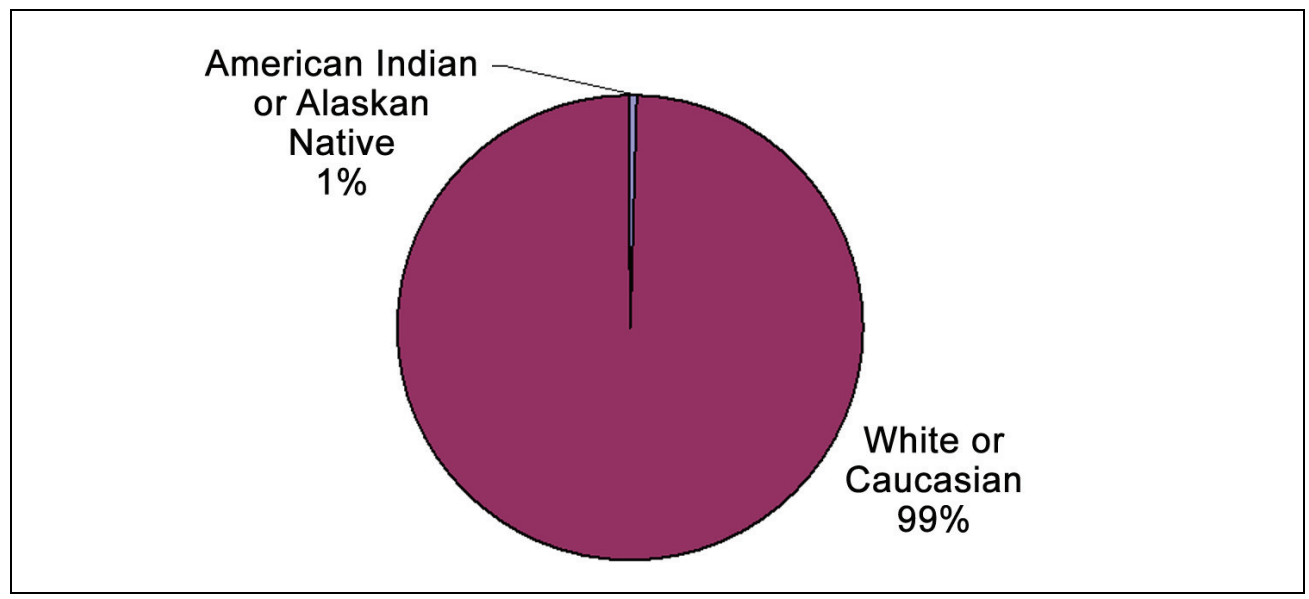

Figure 18. Race of private dock owners at Lake Sidney Lanier, $1999(\mathrm{~N}=332)$ (about 3 percent were Hispanic or of Latino origin). 


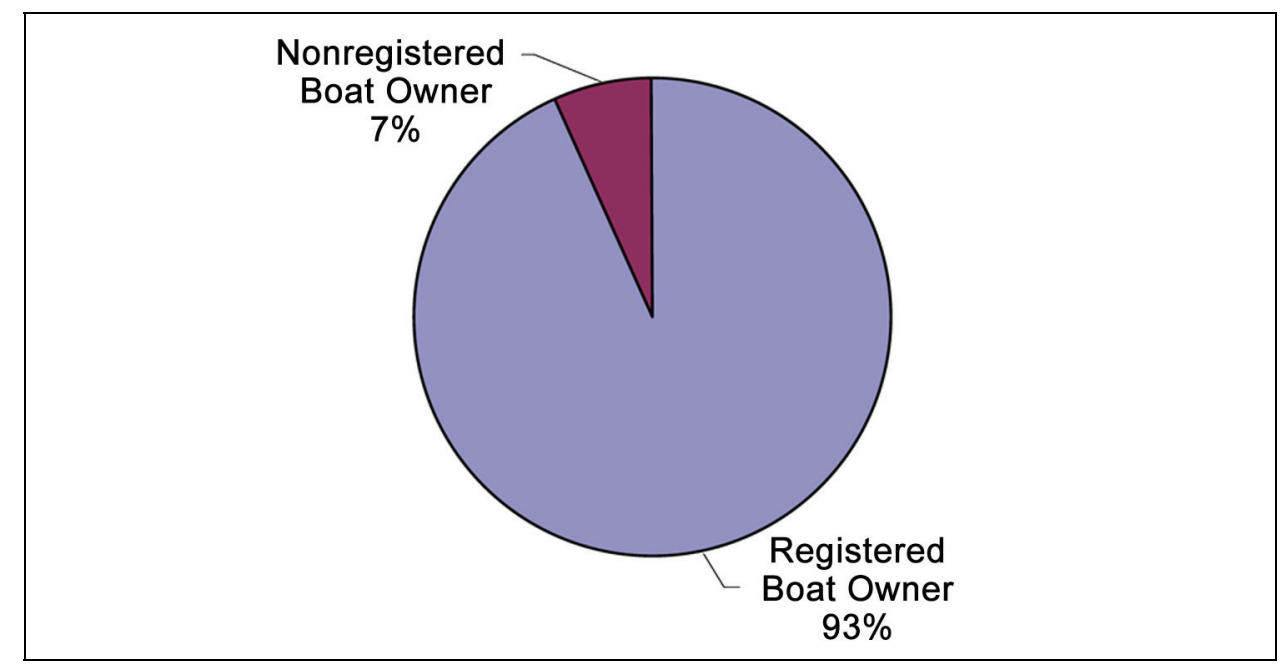

Figure 19. Survey conducted with registered boat owners at Lake Sidney Lanier private docks, 1999 ( $\mathrm{N}=338)$.

Most private dock owners reported high household incomes with no or few children living in the household. Sixty-three percent of the respondents had annual household incomes of at least $\$ 80,000$, with 51 percent reporting incomes of over $\$ 100,000$ (Figure 20). More than half of the owners lived in a household with two or less people and 70 percent of the owners did not have any children age under 18 in their households (Figures 21 and 22). The average number of individuals per household was 2.8 . The most frequent household size (mode) was 2.

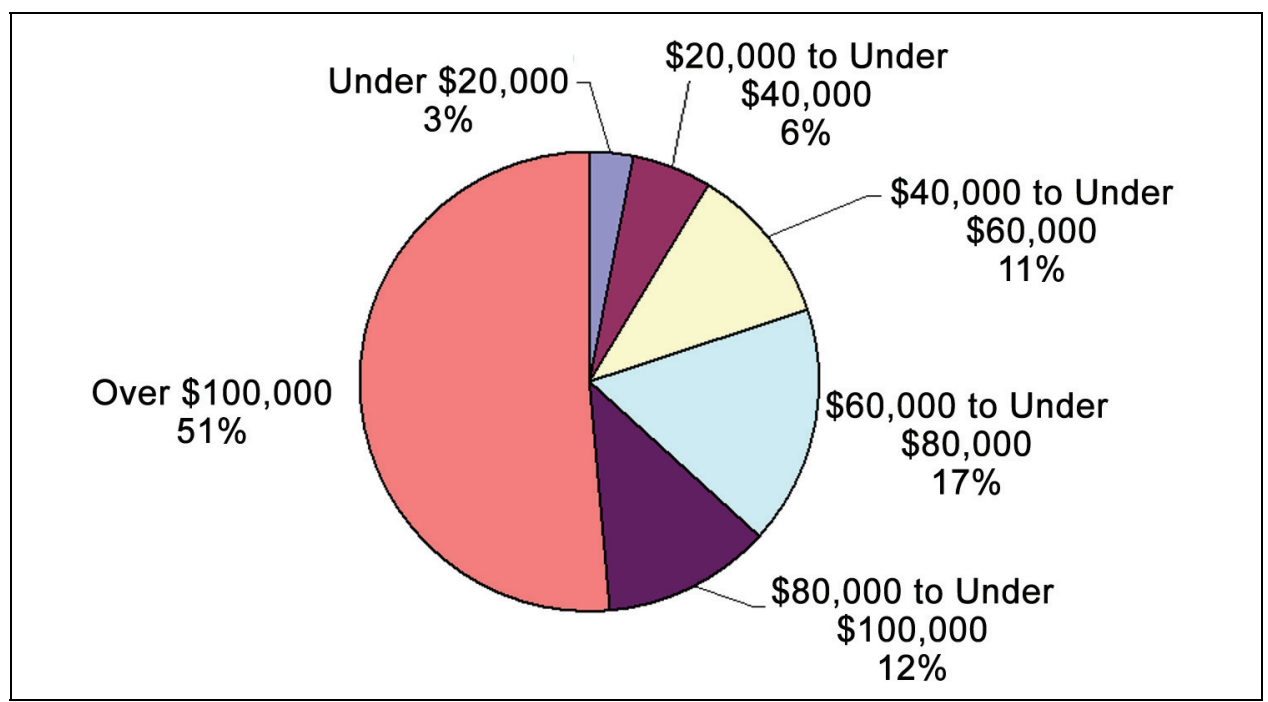

Figure 20. Household income of private dock owners at Lake Sidney Lanier, 1999 (N=300). 


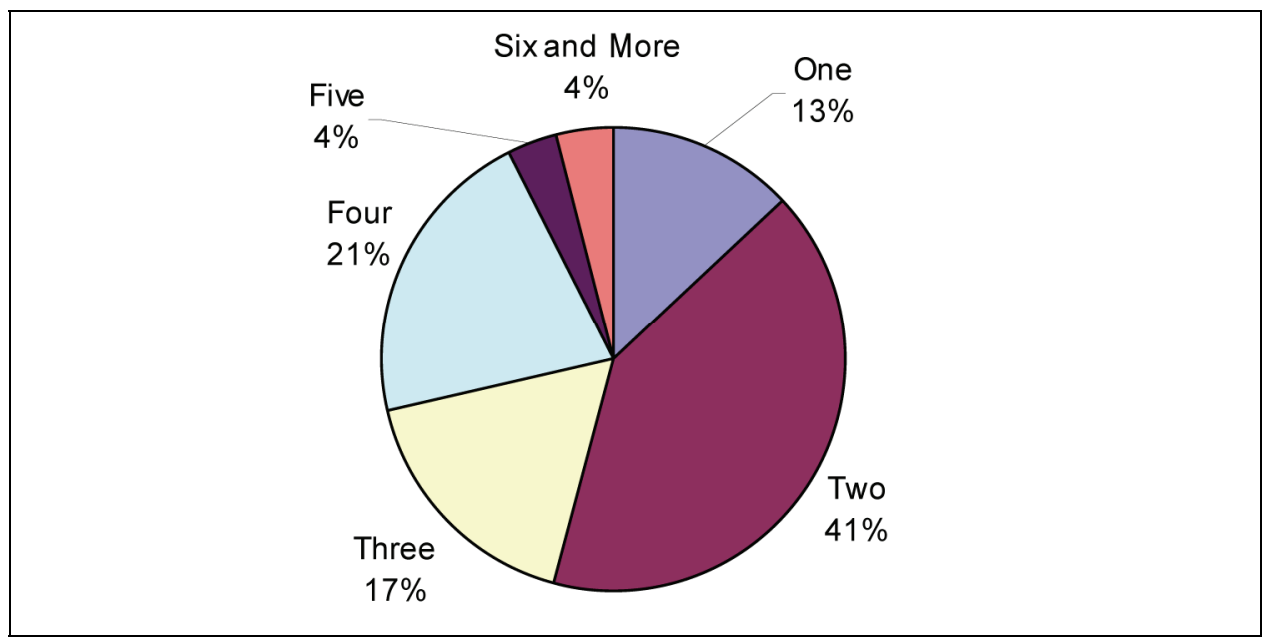

Figure 21. Household size of private dock owners at Lake Sidney Lanier, 1999 ( $\mathrm{N}=337)$.

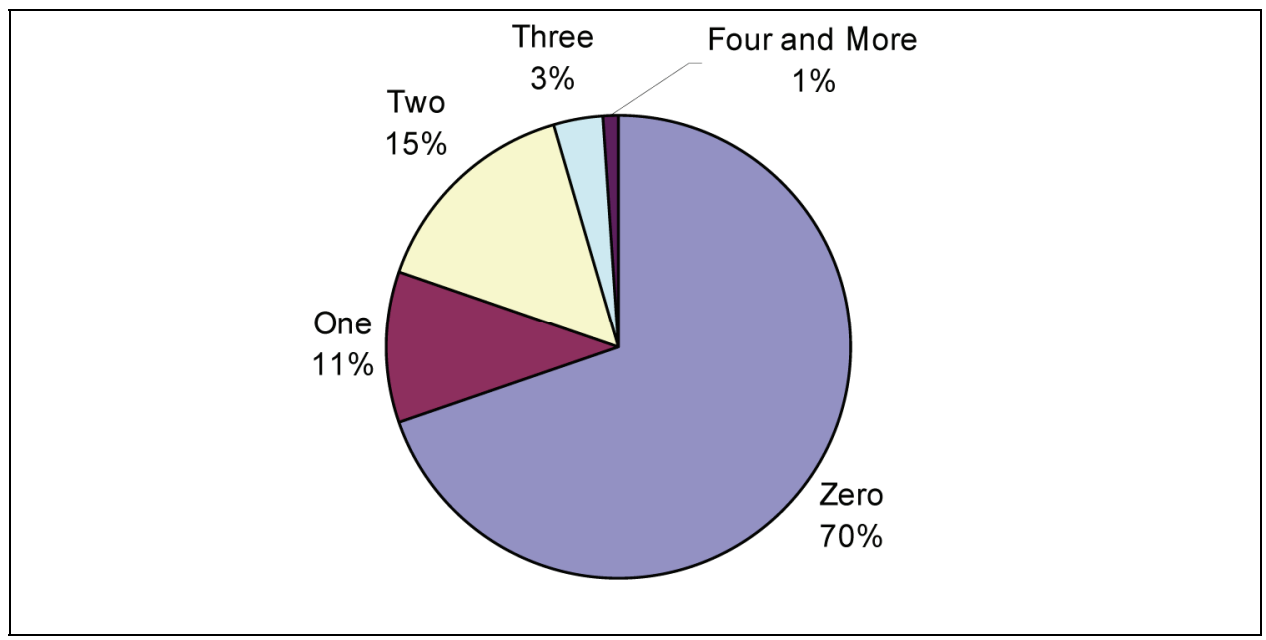

Figure 22. Number of people under 18 in households of private dock owners at Lake Sidney Lanier, 1999 ( $\mathrm{N}=337)$.

The permanent residences of 80 percent of the owners were within 30 miles of the dock (Figure 23). The average distance from the dock owner's permanent home to the private dock was 16 miles. Thirty-two percent of the dock owners owned a seasonal home within 30 miles of the dock (Figure 24). 


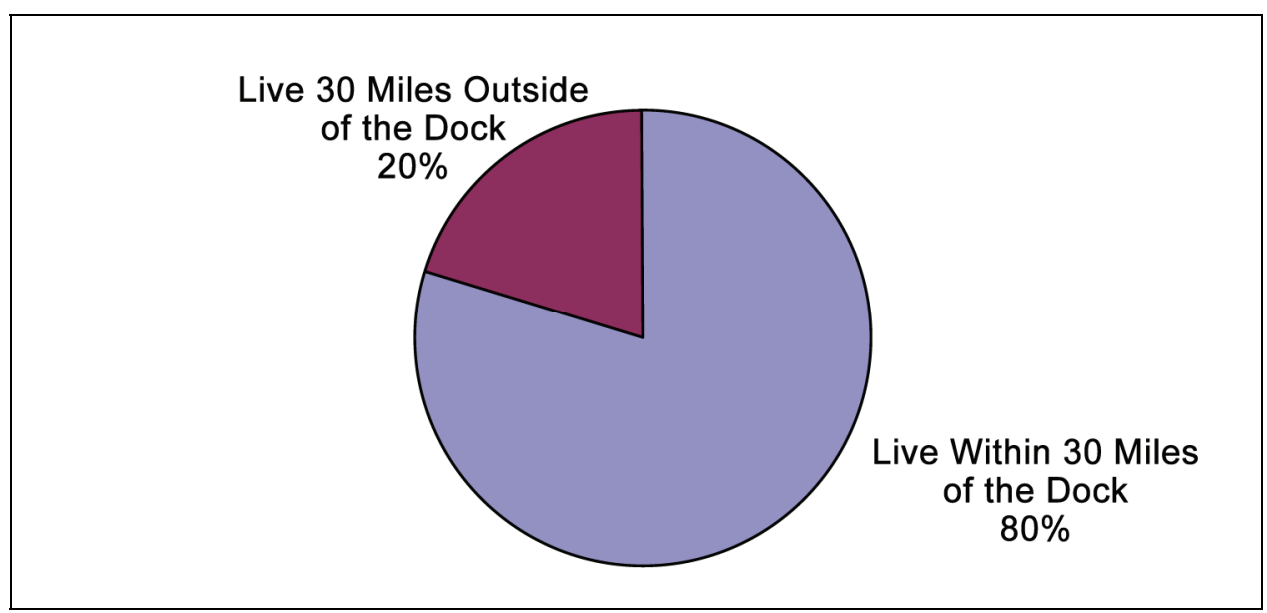

Figure 23. Permanent residence of private dock owners at Lake Sidney Lanier, 1999 $(\mathrm{N}=341)$.

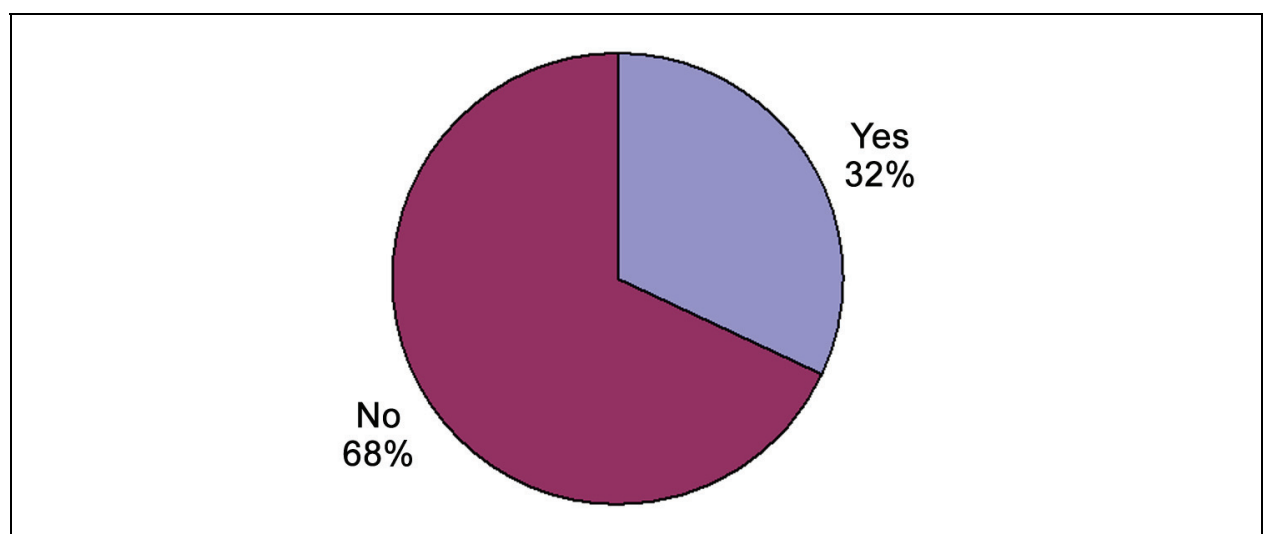

Figure 24. Seasonal home ownership of private dock owners at Lake Sidney Lanier, $1999(\mathrm{~N}=341)$.

\section{Boating characteristics}

Respondents had been boating on Lake Sidney Lanier for an average of 20 years (range $=80$ years). On average, they and their guests (owners/users) took 67 boating trips the previous year from September 1, 1998 to August 31, 1999. ${ }^{1}$ Half of them made 30 or less trips and 25 percent made 80 or more trips in the same period (Table 18). The majority of trips were taken in the summer (26 trips), followed by spring (16), and then fall (14). On average, the fewest number of trips were made in the winter (9 trips per dock owner). When asked to compare the number of boating trips made last year to the previous three years, 68 percent of the owners felt that they had made about the same number of boating trips. Ten per-

\footnotetext{
1 Eighty percent of the sampled dock users had permanent residences within 30 miles of the private dock. Therefore, a large proportion of trips are local in origin.
} 
cent said they had taken more trips last year than in the previous three years, and 22 percent said they had taken fewer trips (Figure 25).

Table 18. Number of trips to Lake Sidney Lanier private boat docks the previous year (09/01/1998 to 08/31/1999).

\begin{tabular}{|c|c|c|c|c|c|c|c|c|}
\hline & \multirow[b]{2}{*}{ Average } & \multirow{2}{*}{$\begin{array}{l}\text { Std. } \\
\text { Error }\end{array}$} & \multirow[b]{2}{*}{ Minimum } & \multirow[b]{2}{*}{ Maximum } & \multicolumn{3}{|c|}{ Percentiles } & \multirow[b]{2}{*}{$\mathrm{N}$} \\
\hline & & & & & $25 \%$ & $50 \%$ & $75 \%$ & \\
\hline Total number of trips & 67.43 & 5.12 & 0 & 365 & 12 & 30 & 80 & 315 \\
\hline Trips made in fall & 13.61 & 1.20 & 0 & 100 & 2 & 6 & 15 & 305 \\
\hline Trips made in winter & 8.84 & 1.04 & 0 & 91 & 0 & 2 & 8 & 305 \\
\hline Trips made in spring & 16.24 & 1.27 & 0 & 100 & 3 & 9 & 20 & 306 \\
\hline Trips made in summer & 26.03 & 2.03 & 0 & 180 & 5 & 12 & 30 & 306 \\
\hline
\end{tabular}

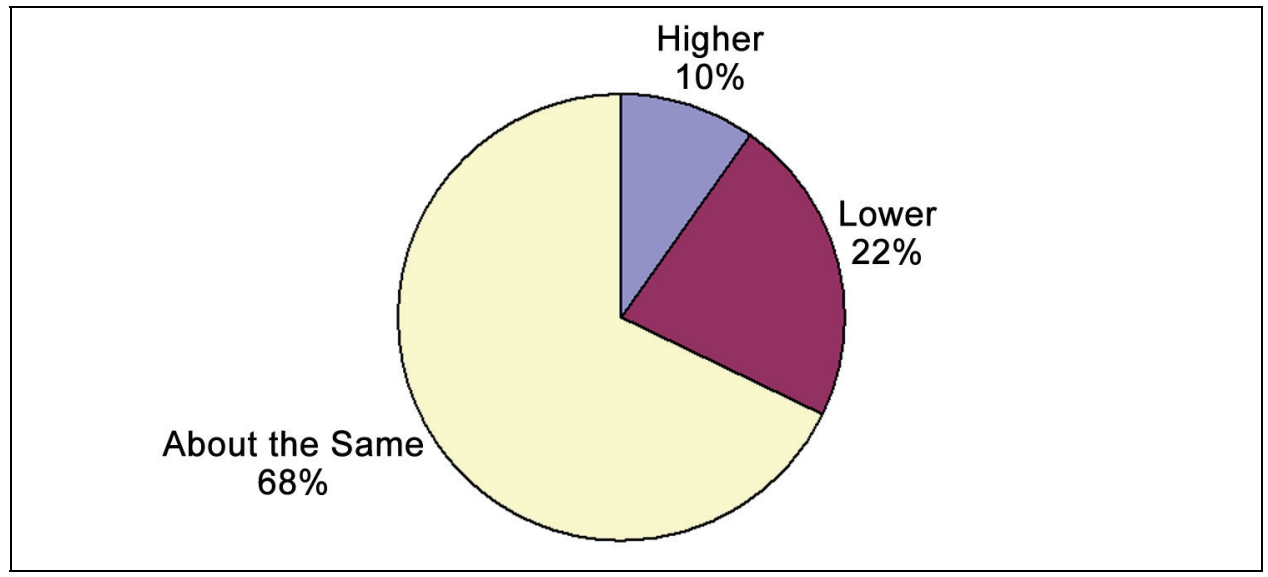

Figure 25. Number of boating trips made by private dock owners last year compared to previous 3-year average at Lake Sidney Lanier, $1999(\mathrm{~N}=307)$.

\section{Activities while boating}

During their boating trips the previous year, dock owners/users went swimming an average of 25 times during roughly a third of their trips (Table 19). Other activities they participated in during their boating trips including picnicking (on 16 percent of their boating trips), fishing from boats (14 percent), water skiing (18 percent), and fishing from shore (10 percent). The participation rates for scuba diving, camping, hiking, and hunting were all less than 5 percent of the total boating trips. Thirty-five percent of the dock owners/users reported participating in other activities that were not mentioned during the telephone interviews (Figure 26). On average, dock owners/users participated in other activities 10 times during 15 percent of their boating trips the previous year (Table 19). The most frequent other activities were socializing (7 percent of respondents) and pleasure boating (6 percent) (Figure 26). 
Table 19. Recreation activity participation during previous year's trips to Lake Sidney Lanier private boat docks, (09/01/1998 to 08/31/1999).

\begin{tabular}{||l|l|l|l|l|l|l||}
\hline Activity & Mean $^{1}$ & $\begin{array}{l}\text { Percent of } \\
\text { Total Trips }\end{array}$ & $\begin{array}{l}\text { Std. Error } \\
\text { of mean }\end{array}$ & Minimum & Maximum & N \\
\hline \hline Boating & 33.39 & $49.51 \%$ & 2.50 & 0 & 300 & 299 \\
\hline Swimming & 25.12 & $37.26 \%$ & 1.88 & 0 & 200 & 300 \\
\hline Picnicking & 10.48 & $15.54 \%$ & 1.14 & 0 & 150 & 304 \\
\hline Fishing from boat & 9.50 & $14.09 \%$ & 1.00 & 0 & 125 & 303 \\
\hline Water skiing & 12.02 & $17.82 \%$ & 1.17 & 0 & 150 & 303 \\
\hline Camping & 1.79 & $2.65 \%$ & 1.00 & 0 & 300 & 304 \\
\hline Hiking & 3.20 & $4.75 \%$ & 1.27 & 0 & 365 & 303 \\
\hline Fishing from shore & 6.86 & $10.18 \%$ & 0.99 & 0 & 200 & 300 \\
\hline Scuba diving & 0.30 & $0.45 \%$ & 0.11 & 0 & 20 & 303 \\
\hline Hunting & 0.22 & $0.33 \%$ & 0.07 & 0 & 15 & 304 \\
\hline Other activities & 10.43 & $15.46 \%$ & 1.73 & 0 & 300 & 299 \\
\hline \hline $\begin{array}{l}1 \text { Times participated in listed activity during previous year's boating trip. } \\
2 \text { Times participated in the listed activity divided by total number of boating trips made the previous year. }\end{array}$ \\
\hline
\end{tabular}

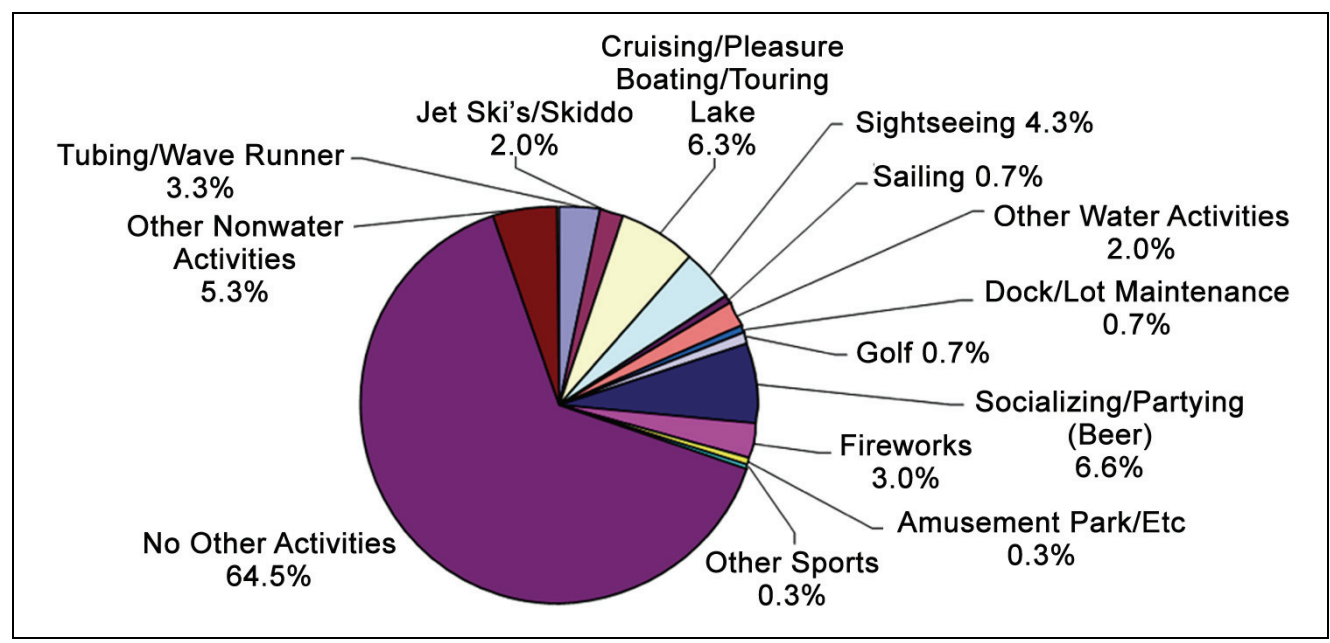

Figure 26. "What other activities did you or others participate in during your boating trips last year that I have not already mentioned?" (from Lake Sidney Lanier private docks, 1999, $\mathrm{N}=301)$.

\section{Type of boat and motor}

Forty-two percent of the boats surveyed at Lake Sidney Lanier private docks were 21 to $30 \mathrm{ft}$ long (Table 20). Fifty-five percent were $20 \mathrm{ft}$ and under with a minimum of $8 \mathrm{ft}$, and 3 percent were $31 \mathrm{ft}$ and larger with a maximum of $90 \mathrm{ft}$. Open and pwc boats were mostly $20 \mathrm{ft}$ and smaller, while cabin cruisers, pontoon, and sailboats were mostly 21 to $30 \mathrm{ft}$ long. 
Table 20. Boat type and length cross-tabulation, Lake Sidney Lanier private dock owner survey, $1999(\mathrm{~N}=277)$.

\begin{tabular}{|c|c|c|c|c|c|c|c|}
\hline \multirow[b]{2}{*}{ Boat Length } & \multicolumn{6}{|c|}{ Boat Type } & \multirow[b]{2}{*}{ Total } \\
\hline & Open & Cabin & Sailboat & Pontoon & House & PWC & \\
\hline 20 and smaller & $44.77 \%$ & $0.36 \%$ & $0.72 \%$ & $3.61 \%$ & $0.36 \%$ & $5.42 \%$ & $55.23 \%$ \\
\hline $21^{\prime}$ to $30^{\prime}$ & $16.97 \%$ & $5.78 \%$ & $2.53 \%$ & $16.25 \%$ & $0.00 \%$ & $0.00 \%$ & $41.52 \%$ \\
\hline 31' and larger & $0.00 \%$ & $2.53 \%$ & $0.00 \%$ & $0.36 \%$ & $0.36 \%$ & $0.00 \%$ & $3.25 \%$ \\
\hline Total & $61.73 \%$ & $8.66 \%$ & $3.25 \%$ & $20.22 \%$ & $0.72 \%$ & $5.42 \%$ & $100.00 \%$ \\
\hline
\end{tabular}

Fifty-nine percent of the boats used at private docks had outboard motors. The majority of sail boats, pontoon boats, and open boats had outboard motors, while most cabin boats did not (Table 21). Houseboats were evenly divided between in- and outboard motors. In general, the smaller boats ( $30 \mathrm{ft}$ and below) had the greatest percentage of outboard motors (Table 22).

Table 21. Boat type and motor cross-tabulation, Lake Sidney Lanier private dock owner survey, $1999(\mathrm{~N}=276)$.

\begin{tabular}{|c|c|c|c|c|c|c|c|}
\hline \multirow[b]{2}{*}{ Inboard Motor } & \multicolumn{6}{|c|}{ Boat Type } & \multirow[b]{2}{*}{ Total } \\
\hline & Open & Cabin & Sailboat & Pontoon & House & PWC & \\
\hline With & $27.54 \%$ & $5.43 \%$ & $0.36 \%$ & $2.90 \%$ & $0.36 \%$ & $3.99 \%$ & $40.58 \%$ \\
\hline Without & $34.42 \%$ & $3.26 \%$ & $2.90 \%$ & $17.03 \%$ & $0.36 \%$ & $1.45 \%$ & $59.42 \%$ \\
\hline Total & $61.96 \%$ & $8.70 \%$ & $3.26 \%$ & $19.93 \%$ & $0.72 \%$ & $5.43 \%$ & $100.00 \%$ \\
\hline
\end{tabular}

Table 22. Boat length and motor cross-tabulation, Lake Sidney Lanier private dock owner survey, $1999(\mathrm{~N}=272)$.

\begin{tabular}{|l|c|c|c|c||}
\hline \multirow{2}{*}{ Inboard Motor } & \multicolumn{3}{|c|}{ Boat Length } & \multirow{2}{*}{ Total } \\
\cline { 2 - 4 } & $20^{\prime}$ and Smaller & 21' to 30' & 31' and Larger & \multicolumn{1}{|c|}{ ' $30.44 \%$} \\
\hline \hline With & $25.00 \%$ & $13.24 \%$ & $2.21 \%$ & $59.56 \%$ \\
\hline Without & $30.51 \%$ & $27.94 \%$ & $1.10 \%$ & $100.00 \%$ \\
\hline Total & $55.51 \%$ & $41.18 \%$ & $3.31 \%$ & $1 \%$ \\
\hline
\end{tabular}

\section{Dock user segments and spending}

Spending averages were estimated for all Lake Sidney Lanier's private dock users (Table 23) and for two different segments based on length of stay (Table 24) and boat length (Table 25). Dividing visitors into segments helps explain differences in spending across distinct user groups. It gives managers the opportunity to apply these distinct spending profiles to 
project level use data. The two types of segments that fulfilled these purposes were: day user versus overnight stay segments and segments based on length of the boat.

\section{Average spending for full sample of dock owners}

Private dock users averaged $\$ 138$ in trip expenses associated with their last boating trip (for a party of 3.8 people). Dock users stayed away from home an average of 0.6 nights and used their boat 1.3 days during their last trip (Table 23). Sixty-eight percent (\$94) of spending occurred within 30 miles of their boat dock. Of the expenditures made within 30 miles of their docks, dock users spent roughly the same amount on gas and oil for their boat and restaurant meals ( $\$ 22$ per party trip), followed by groceries (\$19), sporting goods (\$7), and other boat expenses (\$7). An average of 67 boating trips were made from each slip in a private dock during the previous year.

A private dock is permitted under a shoreline use permit. The applicant is charged a $\$ 30$ fee for a 5 -year permit, which includes a $\$ 10$ administration charge and a $\$ 5$ annual inspection fee. Other storage fees that are identified in annual spending do not include the permit fee but relate to additional spending that may be paid by the end user; for example, in off-site storage when the craft is not in the water.

Dock owners spent an average of $\$ 119$ on storage fees, $\$ 293$ on insurance, $\$ 375$ on boat repair and maintenance, and $\$ 465$ on dock repair and maintenance (Table 23). The average cost of the boat was $\$ 20,285$ (1999 dollars). The lowest boat cost was $\$ 690$ and the highest was over $\$ 460,000$.

Seventy-eight percent of the dock owners answered that they spent about the same on their last trip compared to other trips taken in the past 12 months. About 9 percent reported that they spent more than they did on other trips and 13 percent answered they spent less (Figure 27). 
Table 23. Summary of Lake Sidney Lanier private dock owners'/users' spending and use profiles, 09/1998 to 08/1999 (spending per party trip).

\begin{tabular}{|c|c|c|c|c|c|c|c|c|}
\hline Spending Categories & Mean & $\begin{array}{l}\text { Std. } \\
\text { Error }\end{array}$ & $\begin{array}{l}\text { Pct. } \\
\text { Error }^{1}\end{array}$ & $N$ & Minimum & Maximum & $\begin{array}{l}\text { Pct. } \\
\text { Zeroes }\end{array}$ & $\begin{array}{l}\text { Mean } \\
\text { Exc. Zero }\end{array}$ \\
\hline \multicolumn{9}{|c|}{ Spending Information for Last Trip } \\
\hline Gas/oil auto & $\$ \$ 4.04$ & $\$ 0.68$ & $17 \%$ & 335 & $\$ 0$ & $\$ 140$ & $77 \%$ & \$17.56 \\
\hline Other expenses auto & $\$ 0.49$ & $\$ 0.18$ & $36 \%$ & 338 & $\$ 0$ & $\$ 35$ & $97 \%$ & $\$ 16.60$ \\
\hline Gas/oil boat & $\$ 21.22$ & $\$ 1.71$ & $8 \%$ & 329 & $\$ 0$ & $\$ 300$ & $21 \%$ & $\$ 26.75$ \\
\hline Other expenses boat & $\$ 7.29$ & $\$ 1.92$ & $26 \%$ & 333 & $\$ 0$ & $\$ 450$ & $87 \%$ & $\$ 57.83$ \\
\hline Food/drink restaurants & $\$ 22.57$ & $\$ 2.61$ & $12 \%$ & 332 & $\$ 0$ & $\$ 410$ & $60 \%$ & $\$ 55.92$ \\
\hline Groceries & $\$ 19.12$ & $\$ 1.88$ & $10 \%$ & 331 & $\$ 0$ & $\$ 200$ & $47 \%$ & $\$ 35.75$ \\
\hline Campground fees & $\$ 0.03$ & $\$ 0.03$ & $100 \%$ & 334 & $\$ 0$ & $\$ 10$ & $100 \%$ & $\$ 10.00$ \\
\hline Lodging & $\$ 1.15$ & $\$ 0.93$ & $81 \%$ & 335 & $\$ 0$ & $\$ 300$ & $99 \%$ & $\$ 192.50$ \\
\hline Recreation fees & $\$ 4.30$ & $\$ 1.53$ & $36 \%$ & 335 & $\$ 0$ & $\$ 400$ & $95 \%$ & $\$ 90.00$ \\
\hline Sporting goods & $\$ 7.23$ & $\$ 2.01$ & $28 \%$ & 335 & $\$ 0$ & $\$ 500$ & $88 \%$ & $\$ 59.10$ \\
\hline Other supplies & $\$ 6.33$ & $\$ 1.74$ & $28 \%$ & 333 & $\$ 0$ & $\$ 500$ & $78 \%$ & $\$ 28.47$ \\
\hline Total within 30 miles & $\$ 93.77$ & & & & & & & \\
\hline Expenses for $30+$ miles $^{2}$ & $\$ 44.62$ & $\$ 10.33$ & $23 \%$ & 99 & $\$ 0.00$ & $\$ 600.00$ & $64 \%$ & \\
\hline Total trip spending 2 & $\$ 138.39$ & & & & & & & \\
\hline $\begin{array}{l}\text { Pct. of local spending (within } \\
30 \text { miles) }\end{array}$ & $67.76 \%$ & & & & & & & \\
\hline \multicolumn{9}{|c|}{ Use Information for Last Trip } \\
\hline Nights away from home & 0.57 & 0.09 & $16 \%$ & 334 & 0 & 15 & & \\
\hline Days used boat & 1.26 & 0.04 & $3 \%$ & 276 & 1 & 5 & & \\
\hline Number of people on boat & 3.75 & 0.13 & $4 \%$ & 278 & 1 & 20 & & \\
\hline \multicolumn{9}{|c|}{ Annual Spending for Last Year (09/01/98 - 08/31/99) } \\
\hline Storage fees & $\$ 118.62$ & $\$ 23.84$ & $20 \%$ & 279 & $\$ 0$ & $\$ 3,000$ & & \\
\hline Insurance payments & $\$ 293.03$ & $\$ 18.97$ & $6 \%$ & 233 & $\$ 0$ & $\$ 2,500$ & & \\
\hline Boat repair/maintenance & $\$ 374.73$ & $\$ 48.82$ & $13 \%$ & 276 & $\$ 0$ & $\$ 7,000$ & & \\
\hline
\end{tabular}




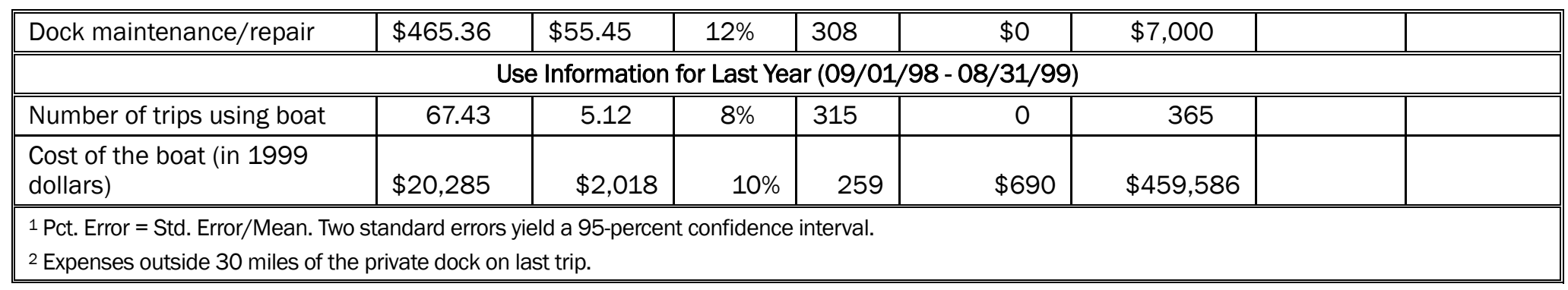




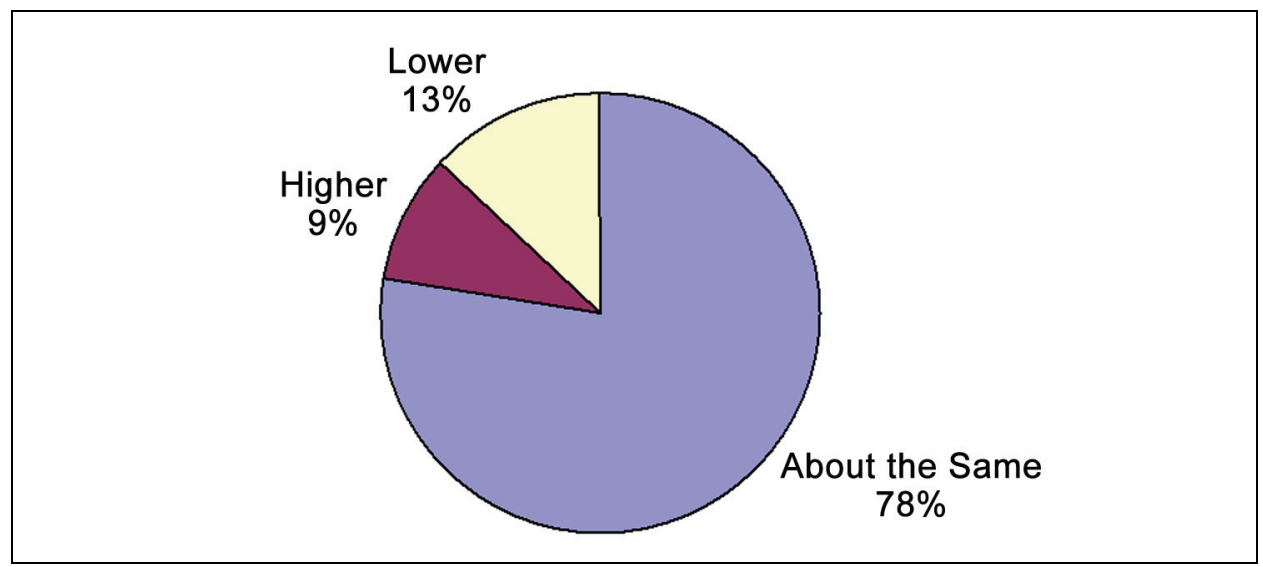

Figure 27. Expenditures by private dock owners/users on most recent trip compared to similar trips in the last 12 months at Lake Sidney Lanier, 1999. $(\mathrm{N}=317)$.

Many of the respondents reported no spending on their last trip in many of the spending categories listed. Categories in which a large percentage (more than 80 percent) of users did not spend money on their last trip were: other expenses on auto (97 percent), other expenses on boat (87 percent), campground fees (100 percent), lodging (99 percent), recreation fees (95 percent), and sporting goods (88 percent). Although the estimates of average trip expenditures in this report are based on the full sample, it is worthwhile to recognize the difference between the average spending of all private dock users and average spending of just the spenders. The average spending of those who spent something on an item is generally much higher than the average computed from all visitors. For instance, while the average across all dock users was $\$ 1.15$ on lodging per party trip, the two private dock parties who did spend money on lodging spent an average of $\$ 193$ per party trip (Table 23). For estimating total spending of all Lanier private dock users, it is appropriate to apply the means that include zeros. The means without zeros should not be used to expand the data to population totals, as they only represent spending for specific segments (i.e., dock users who stayed in hotels spent an average of $\$ 193$ on lodging per trip).

\section{Average spending by segment: Day use vs. overnight}

Lanier dock owners were grouped into two segments based on whether or not they stayed overnight away from their permanent home during their last trip. The dock owners/users who did not stay away from home (i.e., day users) spent an average of \$94 for that trip, 70 percent (\$65) of which was spent within 30 miles of the boat dock (Table 24). The average party 
Table 24. Spending and use by length of stay segments, Lake Sidney Lanier private dock owner survey, 09/1998 to 08/1999 (spending per party trip).

\begin{tabular}{|c|c|c|c|c|c|c|c|c|}
\hline \multirow[b]{2}{*}{ Spending Categories } & \multicolumn{4}{|c|}{ Day Users } & \multicolumn{4}{|c|}{ Overnight Users } \\
\hline & Mean & $\begin{array}{l}\text { Std. } \\
\text { Error }\end{array}$ & $\begin{array}{l}\text { Pct. } \\
\text { Error }^{1}\end{array}$ & $\mathrm{~N}$ & Mean & $\begin{array}{l}\text { Std. } \\
\text { Error }\end{array}$ & $\begin{array}{c}\text { Pct. } \\
\text { Error }^{1}\end{array}$ & $\mathrm{~N}$ \\
\hline \multicolumn{9}{|c|}{ Per Party Trip Spending } \\
\hline Gas/oil auto & \$1.26 & $\$ \$ 0.30$ & $24 \%$ & 258 & \$13.53 & $\$ 2.62$ & $19 \%$ & 73 \\
\hline Other expenses auto & $\$ 0.10$ & $\$ 0.06$ & $58 \%$ & 258 & $\$ 1.87$ & $\$ 0.76$ & $41 \%$ & 75 \\
\hline Gas/oil boat & $\$ 17.66$ & $\$ 1.32$ & $7 \%$ & 253 & $\$ 33.41$ & $\$ 5.96$ & $18 \%$ & 73 \\
\hline Other expenses boat & $\$ 6.48$ & $\$ 2.16$ & $33 \%$ & 255 & $\$ 10.49$ & $\$ 4.41$ & $42 \%$ & 74 \\
\hline Restaurants & $\$ 17.68$ & $\$ 2.45$ & $14 \%$ & 254 & $\$ 39.76$ & $\$ 7.74$ & $19 \%$ & 75 \\
\hline Groceries & $\$ 11.78$ & $\$ 1.54$ & $13 \%$ & 255 & $\$ 44.91$ & $\$ 5.56$ & $12 \%$ & 74 \\
\hline Campground fees & $\$ 0.00$ & - & - & 255 & $\$ 0.13$ & $\$ 0.13$ & $100 \%$ & 75 \\
\hline Lodging & $\$ 0.00$ & - & - & 256 & $\$ 5.13$ & $\$ 4.14$ & $81 \%$ & 75 \\
\hline Recreation fees & $\$ 3.61$ & $\$ 1.75$ & $48 \%$ & 256 & $\$ 6.87$ & $\$ 3.30$ & $48 \%$ & 75 \\
\hline Sporting goods & $\$ 3.21$ & $\$ 1.04$ & $32 \%$ & 256 & $\$ 21.33$ & $\$ 8.07$ & $38 \%$ & 75 \\
\hline Other supplies & $\$ 3.44$ & $\$ 0.65$ & $19 \%$ & 255 & $\$ 16.41$ & $\$ 7.33$ & $45 \%$ & 75 \\
\hline Total within 30 miles & $\$ 65.23$ & & & & $\$ 193.84$ & & & \\
\hline Expenses $30+$ miles $^{2}$ & $\$ 28.40$ & $\$ 13.10$ & $46 \%$ & 52 & $\$ 57.73$ & $\$ 16.39$ & $28 \%$ & 44 \\
\hline Total trip spending & $\$ 93.64$ & & & & $\$ 251.57$ & & & \\
\hline $\begin{array}{l}\text { Pct. of local spending (within } \\
30 \text { miles) }\end{array}$ & $70 \%$ & & & & $77 \%$ & & & \\
\hline \multicolumn{9}{|c|}{ Annual Spending } \\
\hline Storage fees & $\$ 99.93$ & $\$ 26.60$ & $27 \%$ & 209 & $\$ 172.88$ & $\$ 54.11$ & $31 \%$ & 66 \\
\hline Insurance payments & $\$ 269.21$ & $\$ 17.95$ & $7 \%$ & 179 & $\$ 364.08$ & $\$ 57.11$ & $16 \%$ & 51 \\
\hline Boat repair/maintenance & $\$ 331.02$ & $\$ 53.17$ & $16 \%$ & 207 & $\$ 529.31$ & $\$ 118.06$ & $22 \%$ & 65 \\
\hline Dock maintenance/repair & $\$ 451.44$ & $\$ 61.87$ & $14 \%$ & 231 & $\$ 530.63$ & $\$ 131.45$ & $25 \%$ & 71 \\
\hline $\begin{array}{l}\text { Cost of the boat (in } 1999 \\
\text { dollars) }\end{array}$ & $\$ 18,063$ & $\$ 1,250$ & $7 \%$ & 195 & $\$ 26,854$ & $\$ 7,550$ & $28 \%$ & 61 \\
\hline \multicolumn{9}{|c|}{ Visitor Characteristics } \\
\hline $\begin{array}{l}\text { Total trips using boat (last } \\
\text { year) }\end{array}$ & 76.11 & 6.45 & $8 \%$ & 235 & 43.62 & 6.47 & $15 \%$ & 74 \\
\hline $\begin{array}{l}\text { Nights away from home (last } \\
\text { trip) }\end{array}$ & 0.00 & - & - & 259 & 2.52 & 0.31 & $12 \%$ & 75 \\
\hline Days used boat (last trip) & 1.00 & - & - & 209 & 2.03 & 0.10 & $5 \%$ & 66 \\
\hline People on boat (last trip) & 3.70 & 0.14 & $4 \%$ & 210 & 3.94 & 0.32 & $8 \%$ & 66 \\
\hline
\end{tabular}


size was 3.7 people per trip. The dock owners/users who stayed overnight spent an average of 2.5 nights away from home and used the boat for 2 days with a party size of 3.9 people per trip. They spent an average $\$ 252$ for the entire trip, 77 percent (\$194) of which was spent within 30 miles of the boat dock. Day users made an average of 76 boating trips in the previous year, whereas overnight dock users made 44 trips.

Dock owners in the overnight segment owned more expensive boats than day users ( $\$ 26,854$ vs. $\$ 18,063$, respectively). Consequently, they paid more annually in storage fees, insurance payments, and repairs and maintenance than day users.

For private dock users, there were more than three times as many day users as overnight visitors in the sample (78 percent versus 22 percent, respectively). In terms of total spending in the local region, day use dock users contributed 67 percent, and overnight stay dock users, 33 percent.

\section{Average spending by boat length segments}

Based on the length of the boat, the dock owners were grouped into three segments: boats that were $20 \mathrm{ft}$ and shorter, boats between 21 and $30 \mathrm{ft}$, and boats $31 \mathrm{ft}$ and longer. In general, as boat size increased so did the amount of expenditures, particularly when going from the middle to the longest category. The 20-ft and smaller segment spent an average of \$134 per party on the last trip during which about 68 percent (\$91) was spent within 30 miles of the boat dock (Table 25). They stayed an average of 0.6 night away from home and used their boat for 1.3 days, with a party size of 3.5 people per trip. Dock owners/users in this segment made an average of 75 boating trips the previous year.

The 21- to 30-ft boat segment spent an average of $\$ 154$ per party on the last trip ( $\$ 114$ within 30 miles of the boat dock). They stayed an average of 0.5 nights away from home, used their boat for 1.2 days with a party size of 4.1 people per trip. They made an average of 73 boating trips the previous year. Dock owners/users in the largest boat size segment averaged more than $\$ 259$ per party on goods and services during their last trip, ( $\$ 197$ of the money was spent locally). They stayed away from home an average of 1.4 nights and used the boat for 1.6 days per trip. The average party size for this group was 3.4 people per trip. Owners/users in this segment made an average of 133 boating trips the previous year. 
Table 25. Spending and use by boat length segments, Lake Sidney Lanier private dock owner survey, 09/1998 to 08/99 (spending per party trip).

\begin{tabular}{|c|c|c|c|c|c|c|c|c|c|c|c|c|}
\hline \multirow[b]{2}{*}{ Spending Categories } & \multicolumn{4}{|c|}{ 20' and Smaller } & \multicolumn{4}{|c|}{$21^{\prime}$ to $30^{\prime}$} & \multicolumn{4}{|c|}{ 31' and Larger } \\
\hline & Mean & $\begin{array}{l}\text { Std. } \\
\text { Error }\end{array}$ & $\begin{array}{l}\text { Pct. } \\
\text { Error }^{1}\end{array}$ & $\mathrm{~N}$ & Mean & $\begin{array}{l}\text { Std. } \\
\text { Error }\end{array}$ & $\begin{array}{l}\text { Pct. } \\
\text { Error }^{1}\end{array}$ & $\mathrm{~N}$ & Mean & $\begin{array}{l}\text { Std. } \\
\text { Error }\end{array}$ & $\begin{array}{l}\text { Pct. } \\
\text { Error }^{1}\end{array}$ & $\mathrm{~N}$ \\
\hline \multicolumn{13}{|c|}{ Per Party Trip Spending } \\
\hline Gas/oil auto & $\$ 4.59$ & $\$ 1.19$ & $26 \%$ & 151 & $\$ 3.17$ & $\$ 1.04$ & $33 \%$ & 113 & $\$ 4.67$ & $\$ 2.38$ & $51 \%$ & 9 \\
\hline Other expenses auto & $\$ 0.30$ & $\$ 0.16$ & $54 \%$ & 152 & $\$ 0.87$ & $\$ 0.44$ & $51 \%$ & 115 & $\$ 2.22$ & $\$ 2.22$ & $100 \%$ & 9 \\
\hline Gas/oil boat & $\$ 19.03$ & $\$ 1.40$ & $7 \%$ & 147 & $\$ 27.71$ & $\$ 3.36$ & $12 \%$ & 115 & $\$ 86.25$ & $\$ 33.74$ & $39 \%$ & 8 \\
\hline Groceries & $\$ 19.29$ & $\$ 3.13$ & $16 \%$ & 147 & $\$ 19.65$ & $\$ 2.57$ & $13 \%$ & 115 & $\$ 35.56$ & $\$ 15.84$ & $45 \%$ & 9 \\
\hline Campground fees & $\$ 0.00$ & $\$ 0.00$ & $0 \%$ & 150 & $\$ 0.09$ & $\$ 0.09$ & $100 \%$ & 114 & $\$ 0.00$ & $\$ 0.00$ & $0 \%$ & 9 \\
\hline Lodging & $\$ 2.00$ & $\$ 2.00$ & $100 \%$ & 150 & $\$ 0.74$ & $\$ 0.74$ & $100 \%$ & 115 & $\$ 0.00$ & $\$ 0.00$ & $0 \%$ & 9 \\
\hline Recreation fees & $\$ 3.10$ & $\$ 1.25$ & $40 \%$ & 150 & $\$ 5.00$ & $\$ 2.28$ & $46 \%$ & 115 & $\$ 0.00$ & $\$ 0.00$ & $0 \%$ & 9 \\
\hline Total trip spending & $\$ 134.09$ & & & & $\$ 154.11$ & & & & $\$ 259.33$ & & & \\
\hline Pct. of local spending (within 30 miles) & $68 \%$ & & & & $74 \%$ & & & & $76 \%$ & & & \\
\hline \multicolumn{13}{|c|}{ Annual Spending } \\
\hline Storage fees & $\$ 86.40$ & $\$ 21.54$ & $25 \%$ & 150 & $\$ 93.32$ & $\$ 28.94$ & $31 \%$ & 110 & $\$ 722.22$ & $\$ 433.90$ & $60 \%$ & 9 \\
\hline Insurance payments & $\$ 270.42$ & $\$ 21.43$ & $8 \%$ & 116 & $\$ 291.36$ & $\$ 25.78$ & $9 \%$ & 101 & $\$ 766.43$ & $\$ 315.01$ & $41 \%$ & 7 \\
\hline Boat repair/maintenance & $\$ 282.44$ & $\$ 53.81$ & $19 \%$ & 147 & $\$ 366.77$ & $\$ 71.18$ & $19 \%$ & 111 & $\$ 2155.56$ & $\$ 607.90$ & $28 \%$ & 9 \\
\hline Dock maintenance/repair & $\$ 502.28$ & $\$ 85.28$ & $17 \%$ & 147 & $\$ 377.90$ & $\$ 71.84$ & $19 \%$ & 111 & $\$ 1268.75$ & $\$ 851.94$ & $67 \%$ & 8 \\
\hline Cost of the boat (in 1999 dollars) & $\$ 14,443$ & $\$ 801$ & $6 \%$ & 136 & $\$ 21,488$ & $\$ 1,910$ & $9 \%$ & 109 & $\$ 100,808$ & $\$ 46,155$ & $46 \%$ & 9 \\
\hline \multicolumn{13}{|c|}{ Visitor Characteristics } \\
\hline Total trips using boat (last year) & 75.11 & 8.03 & $11 \%$ & 140 & 73.43 & 8.72 & $12 \%$ & 109 & 132.67 & 39.96 & $30 \%$ & 9 \\
\hline
\end{tabular}




\begin{tabular}{|c|c|c|c|c|c|c|c|c|c|c|c|c|}
\hline Nights away from home (last trip) & 0.64 & 0.15 & $24 \%$ & 149 & 0.54 & 0.15 & $28 \%$ & 114 & 1.44 & 0.78 & "54\% & 9 \\
\hline Days used boat (last trip) & 1.26 & 0.05 & $4 \%$ & 147 & 1.24 & 0.05 & $4 \%$ & 115 & 1.56 & 0.29 & $19 \%$ & 9 \\
\hline People on boat (last trip) & 3.48 & 0.19 & $6 \%$ & 149 & 4.11 & 0.19 & $5 \%$ & 115 & 3.44 & 0.65 & $19 \%$ & 9 \\
\hline
\end{tabular}


The larger the boat, the more dock owners spent on annual expenses. Storage fees ranged from $\$ 86$ for boats $20-\mathrm{ft}$ and shorter to $\$ 722$ for boats $31 \mathrm{ft}$ and longer. The cost of the boat ranged from $\$ 14,443$ for the $20-\mathrm{ft}$ and smaller segment to $\$ 100,808$ for the $31-\mathrm{ft}$ and larger segment, while the insurance payments ranged from $\$ 270$ to $\$ 766$ a year across the three segments. Boat repair and maintenance costs similarly grew from $\$ 282$ to $\$ 2,156$ per year as boat size increased (Table 25).

Nearly half the sample had medium-sized boats (21 to $30 \mathrm{ft}$ ), while more than half were small (under $21 \mathrm{ft}$ ), and 3 percent of the boats were $31 \mathrm{ft}$ and longer. Dock users with large boats contribute 11 percent of total spending locally, dock users with medium-sized boats, 43 percent, and those with small boats, 46 percent.

\section{Total spending}

The figures in Table 26 were derived from secondary data sources, the Natural Resource Management System (NRMS) (USACE 2006c) and from survey data for Lanier (e.g., average number of trips per household or dock permit last year). Applying these figures, Lanier dock users took 540,693 boating party trips in 1999 (21 percent of total recreation use ${ }^{1}$ ) and purchased 354 new boats (Table 26).

Table 26. Total annual use figures for private dock owner survey at Lake Sidney Lanier (1999).

\begin{tabular}{|l|l|l||}
\hline Category & Total Use & Computation Procedures \\
\hline \hline Number of docks & 8,018 & From NRMS (1999) \\
\hline Number of boats & 16,036 & From NRMS (1999) \\
\hline Number of party trips & 540,693 & $\begin{array}{l}\text { Total party trips (from Table 18) times total number } \\
\text { of docks (assuming the total number of trips is on a } \\
\text { per dock basis, reference Foreword) }\end{array}$ \\
\hline $\begin{array}{l}\text { Percent of new boats } \\
\text { purchased last year }\end{array}$ & $4.42 \%$ & $\begin{array}{l}\text { Computed from survey results, using the 3-year } \\
\text { average (1997 to 1999) }\end{array}$ \\
\hline $\begin{array}{l}\text { Number of new boats } \\
\text { purchased last year }\end{array}$ & 354 & $\begin{array}{l}\text { Percent of new boats purchased last year times } \\
\text { total number of docks }\end{array}$ \\
\hline
\end{tabular}

Local and total trip-related spending (Table 27 and 28) is calculated by multiplying the number of party-trips in Table $26(540,693)$ by the trip spending averages in Table 23. Total spending on boats and fixed, annual

17.7 million recreation visits in 1999 from Table 1 divided by an average party size of 3.0 from Propst et al. (1998) equals 2.6 total million party trips; 540,693 is 21 percent of 2.6 million party trips. 
goods and services (Table 29) is estimated by multiplying the number of docks in Table $26(8,018)$ by the annual expenditures on boats, dock repairs and maintenance, and storage in Table 23. Total spending on insurance is estimated by multiplying the number of boats $(16,036)$ by the proportion of local boat dock owners who purchased boat insurance and their average insurance payment. Total spending on purchasing new boats is estimated by multiplying the number of new boats purchased last year (354) by the proportion of local dock owners who bought new boat and the average local new boat cost for three years: 1997-1999.

A recreation visit, as reported in the NRMS data base, is one person entering a Corps project. Spending depends on how long a person stays in the local region rather than how many times they enter the project or how much time they spend in recreation activities while there. Recreation visits are therefore converted to party trips ${ }^{1}$ in the region before applying spending averages. This procedure avoids double-counting the spending of private dock users who may enter the project multiple times on the same day and also takes into account additional days a dock user may spend in the area outside the project.

The estimated trip spending for all Lanier private dock users in was $\$ 51$ million spent within the local region (Table 27). If trip spending outside 30 miles is included, the total rises to $\$ 75$ million (Table 28). Only trip spending within 30 miles of the boat dock ( $\$ 51$ million) should be included when conducting economic impact analysis at the project level (multicounty region).

Fixed, annual goods and services related to boating activities in this study were new boats, storage fees, insurance, and repairs and maintenance. Lanier's private dock owners spent $\$ 20.8$ million (1999 dollars) on boating-related annual goods and services (Table 29). Forty-four percent of the money was spent on the purchase of new boats ( $\$ 9.2$ million), followed by insurance ( $\$ 3.9$ million), dock maintenance and repair ( $\$ 3.7$ million), boat repair and maintenance (\$3.0 million) and storage fees $(\$ 950,000)$.

\footnotetext{
1 See Table 26 for the conversion steps. A party is a travel group staying in the area (within 30 miles of the boat dock). The travel group is usually all individuals in the same vehicle or on the same boat or staying in the same room or campsite. During the interviews, dock owners were asked to report expenditures for their entire party for the last trip. Thus, the units for expenditures are party trips. Converting visits to party trips assures that the units are the same in the multiplication steps that lead to estimates of total expenditures (visits in party trips times expenditures in party trips).
} 
Table 27. Total trip spending in local area ${ }^{1}$ by Lake Sidney Lanier private dock owners/users (1999).

\begin{tabular}{||l|l||}
\hline Spending Category & Spending (\$MM) \\
\hline \hline Gas/oil auto & $\$ 2.18$ \\
\hline Other expenses auto & $\$ 0.27$ \\
\hline Gas/oil boat & $\$ 11.48$ \\
\hline Other expenses boat & $\$ 3.94$ \\
\hline Food/drink restaurants & $\$ 12.20$ \\
\hline Groceries & $\$ 10.34$ \\
\hline Campground fees & $\$ 0.02$ \\
\hline Lodging & $\$ 0.62$ \\
\hline Recreation fees & $\$ 2.32$ \\
\hline Sporting goods & $\$ 3.91$ \\
\hline Other supplies & $\$ 3.42$ \\
\hline Total trip spending & $\$ 50.70$ \\
\hline \hline 1 Local trip spending equals spending within 30 miles of the private dock. \\
\hline
\end{tabular}

Table 28. Total trip spending ${ }^{1}$ by Lake Sidney Lanier private dock owners/users (1999).

\begin{tabular}{||l|l||}
\hline Spending Category & Spending (\$MM) ${ }^{2}$ \\
\hline \hline Gas/oil auto & $\$ 3.67$ \\
\hline Other expenses auto & $\$ 0.45$ \\
\hline Gas/oil boat & $\$ 11.48$ \\
\hline Other expenses boat & $\$ 3.94$ \\
\hline Food/drink restaurants & $\$ 20.55$ \\
\hline Groceries & $\$ 17.40$ \\
\hline Campground fees & $\$ 0.03$ \\
\hline Lodging & $\$ 1.05$ \\
\hline Recreation fees & $\$ 3.91$ \\
\hline $\begin{array}{l}\text { Sporting goods } \\
\text { Other supplies }\end{array}$ & $\$ 6.58$ \\
\hline Total trip spending & $\$ 74.76$ \\
\hline \hline $\begin{array}{l}\text { 1 Total trip spending equals spending within and outside } 30 \text { miles of the dock. } \\
2 \text { Dock owners were asked to report trip spending outside } 30 \text { miles of the private dock as one } \\
\text { total amount, not broken down by item as this table shows. This aggregate spending figure was } \\
\text { then proportionally distributed into all but two categories based on the spending proportions } \\
\text { within 30 miles. Proportional allocations were not made to the "gas/oil boat" and "other expenses } \\
\text { boat" categories. It was assumed that, for these two categories, there were no boating expendi- } \\
\text { tures outside 30 miles of the private dock. }\end{array}$ \\
\hline
\end{tabular}


Table 29. Total spending on fixed, annual goods and services by private dock owners at Lake Sidney Lanier (1999).

\begin{tabular}{|l|l||}
\hline Spending Category & Spending (\$MM) \\
\hline Storage fees & $\$ 0.95$ \\
\hline $\begin{array}{l}\text { Insurance payments (include only payments from dock own- } \\
\text { ers who lived within 30 miles of the private dock) }\end{array}$ & $\$ 3.85$ \\
\hline Boat repair/maintenance & $\$ 3.00$ \\
\hline Dock maintenance/repair & $\$ 3.73$ \\
\hline Purchases of new boats (within 30 miles) & $\$ 9.21$ \\
\hline Total durable goods spending & $\mathbf{\$ 2 0 . 7 5}$ \\
\hline
\end{tabular}

\section{Economic impacts of dock user spending}

\section{9 impacts}

The \$51 million in trip-related spending from Table 27 had a direct economic impact on the region of $\$ 33$ million in direct sales, $\$ 13$ million in personal income (wages and salaries), and supported 622 jobs in the region (Table 30). The eating and drinking (restaurants and bars) sector received the largest amount of direct sales (\$12.2 million), followed by retail trade (\$7.9 million).

Direct effects are less than total spending, as only the retail and wholesale margins on visitor purchases of goods accrue to the local economy. The local region surrounding Lake Sidney Lanier captures 64 percent of dock user spending. Thirty-six percent leaks out of the local economy to cover the costs of imported goods bought by visitors. ${ }^{1}$

The sales multiplier ${ }^{2}$ for the region is 1.61, meaning that an additional 61 cents in sales are generated through secondary effects for every dollar of direct sales. Secondary effects generate an additional 218 jobs, for a total of 840 direct and secondary jobs (Table 30). Likewise, secondary effects generate an additional $\$ 7.5$ million in personal income and $\$ 12$ million in value added (personal income + proprietor's income + indirect business

1 For example, if a visitor buys $\$ 50$ worth of clothing that is not manufactured in the local region, only the local margins (retail and locally operated wholesale and transportation), say $\$ 30$, will be captured by the local economy as direct sales. The remaining $\$ 20$ will leak immediately outside the local economy to cover the producer price (or price of good at the factory), and non-local margins (wholesale and transportation).

2 Multipliers for the 16-county region are from a 2000 input-output model estimated with the IMPLAN system. 
Table 30. Regional economic impacts of Lake Sidney Lanier private dock owners'/users' trip spending (1999, for trip spending within 30 miles only).

\begin{tabular}{|c|c|c|c|c|}
\hline \multicolumn{5}{|c|}{$\begin{array}{l}\text { SUMMARY RESULTS TABLE } \\
\text { IMPACTS ON LOCAL ECONOMY }\end{array}$} \\
\hline Economic Measure & & Direct & Multiplier & Total \\
\hline Output/sales (\$MM) & & $\$ 32.57$ & 1.61 & $\$ 52.52$ \\
\hline Total income (\$MM) & & $\$ 12.98$ & 0.63 & $\$ 20.49$ \\
\hline Total value added (\$MM) & & $\$ 19.54$ & 0.98 & $\$ 31.83$ \\
\hline Jobs & & 621.56 & 25.79 & 839.83 \\
\hline \multicolumn{3}{|c|}{ Total visitor spending (\$MM) } & \multicolumn{2}{|l|}{50.70} \\
\hline \multicolumn{3}{|c|}{ Capture rate } & \multicolumn{2}{|l|}{$64 \%$} \\
\hline \multicolumn{3}{|c|}{ Effective spending multiplier } & 1.04 & \\
\hline \multicolumn{5}{|c|}{ Direct Effects } \\
\hline Sector & Sales (\$MM) & Income (\$MM) & $\begin{array}{l}\text { Value Added } \\
(\$ M M)\end{array}$ & Jobs \\
\hline Lodging & $\$ 0.64$ & $\$ 0.27$ & $\$ 0.42$ & 6.92 \\
\hline Eat and drink & $\$ 12.20$ & $\$ 4.72$ & $\$ 6.67$ & 327.67 \\
\hline Amusement and recreation & $\$ 1.55$ & $\$ 0.66$ & $\$ 0.96$ & 59.50 \\
\hline Retail & $\$ 7.91$ & $\$ 3.86$ & $\$ 6.29$ & 148.96 \\
\hline Wholesale & $\$ 4.30$ & $\$ 1.81$ & $\$ 2.99$ & 30.58 \\
\hline Other services & $\$ 1.62$ & $\$ 0.51$ & $\$ 0.69$ & 16.42 \\
\hline Groceries & $\$ 1.29$ & $\$ 0.23$ & $\$ 0.40$ & 6.40 \\
\hline Sporting goods & $\$ 0.07$ & $\$ 0.01$ & $\$ 0.02$ & 0.31 \\
\hline Other manufacturing & $\$ 2.81$ & $\$ 0.87$ & $\$ 1.03$ & 23.86 \\
\hline Government & $\$ 0.18$ & $\$ 0.04$ & $\$ 0.06$ & 0.93 \\
\hline Total & $\$ 32.57$ & $\$ 12.98$ & $\$ 19.54$ & 621.56 \\
\hline \multicolumn{5}{|c|}{ Total Effects } \\
\hline Sector & Sales (\$MM) & Income (\$MM) & $\begin{array}{l}\text { Value Added } \\
(\$ M M)\end{array}$ & Jobs \\
\hline Lodging & $\$ 0.92$ & $\$ 0.39$ & $\$ 0.61$ & 10.02 \\
\hline Eat and drink & $\$ 12.89$ & $\$ 4.99$ & $\$ 7.04$ & 346.16 \\
\hline Amusement and recreation & $\$ 1.95$ & $\$ 0.83$ & $\$ 1.17$ & 66.73 \\
\hline Retail & $\$ 9.42$ & $\$ 4.60$ & $\$ 7.49$ & 180.67 \\
\hline Wholesale & $\$ 6.30$ & $\$ 2.65$ & $\$ 4.38$ & 44.94 \\
\hline Other services & $\$ 13.00$ & $\$ 4.72$ & $\$ 8.09$ & 130.36 \\
\hline Groceries & $\$ 2.15$ & $\$ 0.39$ & $\$ 0.66$ & 10.74 \\
\hline Sporting goods & $\$ 0.08$ & $\$ 0.01$ & $\$ 0.02$ & 0.41 \\
\hline Other manufacturing & $\$ 5.27$ & $\$ 1.70$ & $\$ 2.11$ & 44.32 \\
\hline Government & $\$ 0.53$ & $\$ 0.21$ & $\$ 0.25$ & 5.47 \\
\hline Total & $\$ 52.52$ & $\$ 20.49$ & $\$ 31.83$ & 839.83 \\
\hline
\end{tabular}


tax). Roughly 12 direct jobs are supported by each million dollars in total dock user spending. Including multiplier effects, each million dollars in total dock user spending supports about 17 jobs.

The $\$ 21$ million in spending on new boats, storage fees, insurance, and repairs/maintenance from Table 29 had a direct economic impact on the region of $\$ 12$ million in direct sales, $\$ 5$ million in personal income (wages and salaries), and supported 128 direct jobs in the region (Table 31). The other manufacturing sector received the largest amount of direct sales (\$6.2 million), followed by other services (\$3.6 million).

Direct effects only accrue to the industries where dock owner spending is directly received. For example, since no money is spent in the Lodging sector from dock owner annual or durable goods spending, that cell is blank in the top sector of Table 31 (Direct Effects). However, other companies receiving direct payments, e. g. insurance companies may hire employees who live in the region and spend money in the local Lodging sector. Since this is a multiplier (secondary) effect upon the Lodging sector, some amount of sales appears in the Lodging cell in the total effects sector of Table 31.

The local region surrounding Lake Sidney Lanier captures $58 \%$ of dock owner spending on new boats and annual services. Forty-two percent leaks out of the local economy to cover the costs of imported boats and services bought by visitors.

The sales multiplier for the region is 1.60 , meaning that 60 cents in sales are generated through secondary effects. However, secondary effects generate an additional 85 jobs, for a total of 213 direct and secondary jobs (Table 31). Likewise, secondary effects generate an additional \$3 million in personal income and $\$ 5$ million in value added (personal income + proprietor's income + indirect business tax). Roughly 6 direct jobs are supported by each million dollars in total dock owner spending for new boats and annual services. Including multiplier effects, each million dollars in total dock owner spending supports about 10 jobs. 
Table 31. Regional economic impacts of Lake Sidney Lanier private dock owners' durable goods and annual spending (1999).

\begin{tabular}{|c|c|c|c|c|}
\hline \multicolumn{5}{|c|}{$\begin{array}{l}\text { SUMMARY RESULTS TABLE } \\
\text { IMPACTS ON LOCAL ECONOMY }\end{array}$} \\
\hline \multicolumn{2}{|l|}{ Economic Measure } & Direct & Multiplier & Total \\
\hline \multicolumn{2}{|l|}{ Output/sales (\$MM) } & $\$ 12.08$ & 1.60 & $\$ 19.35$ \\
\hline \multicolumn{2}{|l|}{ Total income (\$MM) } & $\$ 5.29$ & 0.68 & $\$ 8.20$ \\
\hline \multicolumn{2}{|l|}{ Total value added (\$MM) } & $\$ 7.11$ & 0.97 & $\$ 11.71$ \\
\hline \multicolumn{2}{|l|}{ Jobs } & 127.78 & 17.64 & 213.00 \\
\hline \multicolumn{3}{|c|}{ Total visitor spending (\$MM) } & \multicolumn{2}{|l|}{20.75} \\
\hline \multicolumn{3}{|l|}{ Capture rate } & \multicolumn{2}{|l|}{$58 \%$} \\
\hline \multicolumn{3}{|c|}{ Effective spending multiplier } & \multicolumn{2}{|l|}{0.93} \\
\hline \multicolumn{5}{|c|}{ Direct Effects } \\
\hline Sector & $\begin{array}{l}\text { Sales } \\
(\$ M M)\end{array}$ & Income (\$MM) & $\begin{array}{l}\text { Value Added } \\
(\$ M M)\end{array}$ & Jobs \\
\hline Lodging & $\$-$ & $\$-$ & $\$-$ & - \\
\hline Eat and drink & $\$-$ & $\$-$ & $\$-$ & - \\
\hline Amusement and recreation & $\$-$ & $\$-$ & $\$-$ & - \\
\hline Retail & $\$ 1.97$ & $\$ 0.88$ & $\$ 1.49$ & 22.83 \\
\hline Whole sale & $\$ 0.27$ & $\$ 0.11$ & $\$ 0.19$ & 1.86 \\
\hline Other services & $\$ 3.65$ & $\$ 1.14$ & $\$ 1.93$ & 22.21 \\
\hline Groceries & $\$-$ & $\$-$ & $\$-$ & - \\
\hline Sporting goods & $\$-$ & $\$-$ & $\$-$ & - \\
\hline Other manufacturing & $\$ 6.18$ & $\$ 3.16$ & $\$ 3.51$ & 80.88 \\
\hline Government & $\$ 0.00$ & $\$ 0.00$ & $\$ 0.00$ & 0.00 \\
\hline Total & $\$ 12.08$ & $\$ 5.29$ & $\$ 7.11$ & 127.78 \\
\hline \multicolumn{5}{|c|}{ Total Effects } \\
\hline Sector & $\begin{array}{l}\text { Sales } \\
(\$ M M)\end{array}$ & Income (\$MM) & $\begin{array}{l}\text { Value Added } \\
\text { (\$MM) }\end{array}$ & Jobs \\
\hline Lodging & $\$ 0.09$ & $\$ \$ 0.04$ & $\$ 0.06$ & 0.93 \\
\hline Eat and drink & $\$ 0.24$ & $\$ 0.09$ & $\$ 0.13$ & 6.51 \\
\hline Amusement and recreation & $\$ 0.09$ & $\$ 0.04$ & $\$ 0.05$ & 2.17 \\
\hline Retail & $\$ 2.64$ & $\$ 1.21$ & $\$ 2.02$ & 36.67 \\
\hline Whole sale & $\$ 0.84$ & $\$ 0.36$ & $\$ 0.59$ & 5.99 \\
\hline Other services & $\$ 8.19$ & $\$ 2.98$ & $\$ 4.92$ & 71.59 \\
\hline Groceries & $\$ 0.10$ & $\$ 0.02$ & $\$ 0.03$ & 0.52 \\
\hline Sporting goods & $\$ 0.00$ & $\$ 0.00$ & $\$ 0.00$ & 0.00 \\
\hline Other manufacturing & $\$ 7.03$ & $\$ 3.41$ & $\$ 3.85$ & 87.08 \\
\hline Government & $\$ 0.12$ & $\$ 0.06$ & $\$ 0.06$ & 1.55 \\
\hline Total & $\$ 19.35$ & $\$ 8.20$ & $\$ 11.71$ & 213.00 \\
\hline
\end{tabular}




\section{Value of 1999 impacts in 2004 dollars}

The 1999 economic impacts reported above were adjusted to 2004 impacts by multiplying 1999 figures by an average consumer price index of 1.21 (U.S. Department of Labor 2006). The results are presented in Table 32.

Table 32. Regional economic impacts of Lake Sidney Lanier private dock owners'/users' trip and owners' annual spending (in 2004 dollars, for spending within 30 miles only).

\begin{tabular}{|l|c|c|c|c||}
\hline & \multicolumn{2}{|c|}{$\begin{array}{c}\text { Trip Spending } \\
\text { (within 30 miles) }\end{array}$} & \multicolumn{2}{c||}{$\begin{array}{c}\text { Durable Goods and other } \\
\text { Annual Costs Spent Locally }\end{array}$} \\
\hline \hline Total spending (\$MM) & \multicolumn{2}{|c|}{$\$ 61.35$} & \multicolumn{2}{c||}{$\$ 25.11$} \\
\hline \hline & Direct Effects & Total Effects & Direct Effects & Total Effects \\
\hline \hline Output/sales (\$MM) & $\$ 39.41$ & $\$ 63.55$ & $\$ 14.61$ & $\$ 23.41$ \\
\hline Total income (\$MM) & $\$ 15.70$ & $\$ 24.80$ & $\$ 6.40$ & $\$ 9.92$ \\
\hline Total value added (\$MM) & $\$ 23.64$ & $\$ 38.52$ & $\$ 8.60$ & $\$ 14.17$ \\
\hline \hline $\begin{array}{l}\text { Note: Spending and economic effects in this table are in 2004 dollars, as opposed to the } 1999 \text { dollars } \\
\text { reported elsewhere in this report }\end{array}$
\end{tabular}

In 2004 dollars, total private dock user trip spending locally of $\$ 61$ million resulted in \$16 million in the region in personal income and \$24 million in value added (personal income + proprietor's income + indirect business tax).With secondary (multiplier) effects, total impacts locally were $\$ 25$ million in personal income and $\$ 38.5$ million in value added. There is no change to the number of direct jobs (749) in going from Tables 30 and 31 to Table 32. This is because no new expenditures by dock users are being estimated in Table 32. Instead, expenditures from the 1999 survey are being inflated to 2004 dollars. Since there are no new expenditures, there are no additional jobs being created in 2004 .

After converting annual goods and services to 2004 dollars, the results are $\$ 25$ million in private dock owner spending on new boats, storage fees, insurance, and repairs/maintenance. The impacts of annual spending include $\$ 6.4$ million in personal income and $\$ 8.6$ million in value added. With secondary (multiplier) effects, total impacts locally were $\$ 10$ million in personal income and $\$ 14$ million in value added. 


\section{Comparison of Marina Slip Renters and Private Dock Owners}

Surveys for both marina slip renters and private dock owners were conducted at Lake Sidney Lanier. This chapter compares various aspects of these two populations at lake Sidney Lanier, including demographics, visitation, boating, spending, and significance to the local economy.

\section{Demographic profiles (Table 33)}

Marina slip renters were mostly white males with high education and income and residing in households of two to three people (65 percent). This group contains perhaps the highest education and income levels of any segment at any other Corps project. Sixty-two percent of the sample had household incomes exceeding $\$ 100,000$ and 26 percent held graduate degrees.

Private dock owners were similar but were older (49 percent were 56 years old and above, whereas the proportion of marina slip renters in this age class was 26 percent). While income levels were high, there was a lower proportion of private dock owners in the highest income classes as compared to marina slip renters. Three percent of private dock owners were Hispanic or Latino, whereas there were 2 percent Hispanics in the marina slip renter sample. Private dock owners also lived closer to Lanier and owned seasonal homes at a substantially higher rate than marina slip renters.

Table 33. Demographic profiles of marina slip renters $(\mathrm{N}=211)$ and private dock owners $(\mathrm{N}=342)$ at Lake Sidney Lanier, 1999.

\begin{tabular}{|l|l|l||}
\hline & $\begin{array}{l}\text { Marina Slip } \\
\text { Renters }\end{array}$ & $\begin{array}{l}\text { Private Dock } \\
\text { Owners }\end{array}$ \\
\hline \hline Pct. male & $89 \%$ & $75 \%$ \\
\hline Average age & 49 yrs. old & 56 yrs. old \\
\hline Pct. age 46 and above & $63 \%$ & $77 \%$ \\
\hline Pct. with some college education & $90 \%$ & $83 \%$ \\
\hline Pct. with college degrees and beyond & $77 \%$ & $66 \%$ \\
\hline Pct. Caucasian & $96 \%$ & $99 \%$ \\
\hline Pct. with annual household incomes over $\$ 80,000$ & $80 \%$ & $63 \%$ \\
\hline Pct. household size of 2 to 4 persons & $85 \%$ & $80 \%$ \\
\hline Average household size & 2.82 & 2.75 \\
\hline
\end{tabular}




\begin{tabular}{|l|l|l||}
\hline Pct. with no children under 18 living at home & $61 \%$ & $70 \%$ \\
\hline $\begin{array}{l}\text { Pct. whose permanent residence was within 30 miles of } \\
\text { the marina or dock }\end{array}$ & $55 \%$ & $80 \%$ \\
\hline Ave. distance from permanent home to marina or dock & $35 \mathrm{mi}$. & $16 \mathrm{mi}$. \\
\hline $\begin{array}{l}\text { Pct. owning seasonal homes within 30 miles of marina } \\
\text { or dock }\end{array}$ & $3 \%$ & $32 \%$ \\
\hline
\end{tabular}

\section{Boating characteristics (Table 34)}

It is likely that marina slip renters at Lake Sidney Lanier have the highest frequency of large boats of any Corps project. Twenty-three percent of boats were $36 \mathrm{ft}$ and larger with a maximum of $90 \mathrm{ft}$. Open and pontoon boats were mostly $24 \mathrm{ft}$ and smaller, while cabin cruisers and sailboats were mostly 25 to $35 \mathrm{ft}$ in length. All houseboats were $36 \mathrm{ft}$ and longer.

For private dock owners, the reverse is true with regards to boat size. Fiftyfive percent owned boats that were $20 \mathrm{ft}$ or less in length and most of these were of the open boat type. The next largest groups were pontoon and open boats in the 21- to 30-ft range (around 16 percent each type). Private dock owners made almost twice as many trips per year as marina slip renters, the majority of which occurred in the summer months.

Table 34. Boating characteristics of marina slip renters $(\mathrm{N}=211)$ and private dock owners $(\mathrm{N}=342)$ at Lake Sidney Lanier, 1999.

\begin{tabular}{|c|c|c|}
\hline & Marina Slip Renters & Private Dock Owners \\
\hline Ave. years spent boating at Lanier & 10 yrs. & 20 yrs. \\
\hline No. boating trips the previous 12 mos. & 35 & 67 \\
\hline Season(s) of most trips & $\begin{array}{l}\text { Fall, summer, spring } \\
\text { all close }\end{array}$ & Summer dominates \\
\hline $\begin{array}{l}\text { Most frequent activities other than boat- } \\
\text { ing (in \% of trips) }\end{array}$ & $\begin{array}{l}\text { Swimming (51\%), } \\
\text { picnicking (34\%) }\end{array}$ & $\begin{array}{l}\text { Swimming (37\%), water } \\
\text { skiing }(18 \%) \text {, picnicking } \\
(16 \%) \text {, fishing from boat } \\
(14 \%)\end{array}$ \\
\hline Most frequent boat type & Cabin, sail & open \\
\hline Pct. In largest boat size class ${ }^{1}$ & $23 \%$ (> $35 \mathrm{ft})$. & $3 \%(>30 \mathrm{ft})$. \\
\hline Pct. In smallest boat size class ${ }^{1}$ & $28 \%(<25 \mathrm{ft})$. & $55 \%(<21 \mathrm{ft})$. \\
\hline
\end{tabular}




\section{Recreation visitation (Table 35)}

Lake Sidney Lanier hosted 7.7 million recreation visits in 1999, 96 percent of which were by day users. Non-boaters accounted for 4.8 million of total day use visits, and boaters another 2.6 million. Since visitor spending and economic impacts in this report are based on party-days or nights, visits in person-trips are converted into visits in party-days. In 1999, there were nearly 3 million party-days of recreation use at Lake Sidney Lanier.

Table 35. Recreation visitation at Lake Sidney Lanier, 1999.

\begin{tabular}{|l|l||}
\hline Visitor Types & Totals for 1999 from NRMS (1000s) \\
\hline \hline Campers (person-trips) & 79.1 \\
\hline Day users (person-trips) & $7,365.2$ \\
\hline Other overnight ${ }^{1}$ (person-trips) & 220.9 \\
\hline Total visits in person-trips & $7,665.2$ \\
\hline Total visits in party-days & $2,991.9$ \\
\hline \hline 1 Lodging accommodations outside of Corps boundaries. \\
\hline
\end{tabular}

\section{Spending in local counties (Table 36)}

Dock owners took more trips than marina slip renters (541,00o party trips as opposed to 198,000 ) and spent $\$ 18$ million more in total trip-related expenditures. However, total annual expenses by marina slip renters

Table 36. Spending in local counties (within 30 miles of Corps boundary).

\begin{tabular}{|c|c|c|c|c|}
\hline & \multicolumn{2}{|c|}{ Marina Slip Renters } & \multicolumn{2}{|c|}{ Private Dock Owners } \\
\hline & Average & Total (\$MM) & Average & Total (\$MM) \\
\hline Trip-related ${ }^{1}$ per party trip & $\$ 165.60$ & $\$ 32.86$ & $\$ 93.77$ & $\$ 50.70$ \\
\hline \multicolumn{5}{|l|}{ Annual expenses } \\
\hline Slip rental & $\$ 2,258.69$ & $\$ 12.74$ & $\mathrm{n} / \mathrm{a}$ & $\mathrm{n} / \mathrm{a}$ \\
\hline Storage fees & $\$ 91.68$ & $\$ 0.52$ & $\$ 118.62$ & $\$ 0.95$ \\
\hline Insurance & $\$ 509.98$ & $\$ 1.66$ & $\$ 293.03$ & $\$ 3.85$ \\
\hline Boat repair and maintenance & $\$ 1,082.89$ & $\$ 6.11$ & $\$ 374.73$ & $\$ 3.00$ \\
\hline Dock repair and maintenance & $\mathrm{n} / \mathrm{a}$ & $\mathrm{n} / \mathrm{a}$ & $\$ 465.46$ & $\$ 3.73$ \\
\hline $\begin{array}{l}\text { New boats bought locally in } \\
\text { previous year }\end{array}$ & $198^{2}$ & $\$ 10.00$ & $354^{2}$ & $\$ 9.21$ \\
\hline Total annual & & $\$ 31.04$ & & $\$ 20.75$ \\
\hline Ave. cost of boat & $\$ 48,909$ & & $\$ 20,285$ & \\
\hline
\end{tabular}


exceed those of private dock owners by $\$ 8$ million. This difference is due to the added expense of slip rentals and the generally higher annual costs associated with the type and size of boats owned by marina slip renters.

\section{Trip characteristics (Table 37)}

The tendency was for marina slip renters to spend more nights away than private dock owners. This trend was especially true for the largest boat class, which also reported the largest party size (4.26), closely followed by medium boat size for private dock owners (4.11).

Table 37. Trip characteristics (averages for last trip taken), Lake Sidney Lanier, 1999.

\begin{tabular}{||l|l|l|l|l|l|l||}
\hline \multirow{2}{*}{} & \multicolumn{3}{|c|}{ Marina Slip Renters } & \multicolumn{3}{c|}{ Private Dock Owners } \\
\cline { 2 - 8 } & $\begin{array}{l}\text { Nights } \\
\text { Away }\end{array}$ & $\begin{array}{l}\text { Days Boat } \\
\text { Was Used }\end{array}$ & $\begin{array}{l}\text { Party } \\
\text { Size }\end{array}$ & $\begin{array}{l}\text { Nights } \\
\text { Away }\end{array}$ & $\begin{array}{l}\text { Days Boat } \\
\text { Was Used }\end{array}$ & $\begin{array}{l}\text { Party } \\
\text { Size }\end{array}$ \\
\hline \hline All & 1.23 & 1.85 & 3.63 & 0.57 & 1.26 & 3.75 \\
\hline Day users & 0.00 & 1.00 & 3.48 & 0.00 & 1.00 & 3.70 \\
\hline Overnight users & 2.34 & 2.61 & 3.81 & 2.52 & 2.03 & 3.94 \\
\hline $\begin{array}{l}\text { Smallest boat size (<25 ft for } \\
\text { marina; <21 ft for dock) }\end{array}$ & 0.60 & 1.38 & 3.14 & 0.64 & 1.26 & 3.48 \\
\hline $\begin{array}{l}\text { Medium boat size (25-35 ft for } \\
\text { marina; 21-30 ft for dock) }\end{array}$ & 0.94 & 1.68 & 3.60 & 0.54 & 1.24 & 4.11 \\
\hline $\begin{array}{l}\text { Largest boat size (>35 ft marina; } \\
>30 \mathrm{ft} \text { dock) }\end{array}$ & 2.55 & 2.73 & 4.26 & 1.441 & 1.561 & 3.441 \\
\hline 1 Small sample size warning. & & & & & & \\
\hline
\end{tabular}

\section{Significance to local economy (Table 38)}

In general, the economic multipliers that convert recreation spending to economic effects on the local economy are fairly equivalent between marina slip renters and private dock owners.

Table 38. Significance to local economy (trip spending, not durable goods), 1999.

\begin{tabular}{|l|l|l|l|l|l|l|}
\hline & \multicolumn{3}{|c|}{ Marina Slip Renters } & \multicolumn{3}{c|}{ Private Dock Owners } \\
\cline { 2 - 7 } & \multicolumn{1}{|c|}{ Direct } & \multicolumn{1}{|c|}{ Multiplier } & \multicolumn{1}{c|}{ Total } & \multicolumn{1}{|c|}{ Direct } & \multicolumn{1}{|c|}{ Multiplier } & \multicolumn{1}{|c|}{ Total } \\
\hline \hline Output (sales) \$MM & $\$ 19.6$ & 1.60 & $\$ 31.34$ & $\$ 32.57$ & 1.61 & $\$ 52.52$ \\
\hline Total income \$MM & $\$ 7.72$ & 0.62 & $\$ 12.13$ & $\$ 12.98$ & 0.63 & $\$ 20.49$ \\
\hline Value added \$MM & $\$ 11.37$ & 0.97 & $\$ 18.95$ & $\$ 19.54$ & 0.98 & $\$ 31.83$ \\
\hline Employment (\# jobs) & 328 & 23.39 & 456 & 622 & 25.79 & 840 \\
\hline \hline
\end{tabular}




\section{Study Limitations and Error}

The accuracy of the estimates in this report rests on the three inputs: visits, spending averages, and multipliers. The numbers of trips reported by the samples of marina slip renters and of private dock owners and the occupancy rates of the marinas and the number of boats at the docks are likely the largest potential sources of error.

The multipliers and economic ratios used to convert spending to jobs and income and to estimate secondary effects come from an IMPLAN model for the 16-county region. Although it is difficult to estimate the levels of error, multipliers can vary by about 10 percent between different modeling systems. Multipliers largely influence estimates of secondary effects.

Depending on the direction and magnitude of errors in visits, spending, and multipliers, the different errors may compound or cancel each other. The most important potential errors are in the estimates of total trips. As the model is linear, doubling the amount of visitation will double spending and economic impacts.

In addition to these issues, there are also conceptual issues regarding how much and which spending may be claimed by the project. It is not simple to determine if marina slip users (or private dock users) would spend their money elsewhere if marinas (or private docks) were not available at Lake Sidney Lanier. Furthermore, local visitors are usually excluded in estimating economic impacts, but have been included here. Since they are not a distinct segment, their contribution to the total effects is not readily estimated. However, 55 percent of the slip renters interviewed stated that their permanent residences were within 30 miles of the project. Since 89 percent of total trip spending occurred within 30 miles of the project, the impact of local spending is substantial. For private dock owners, 80 percent of those interviewed stated that their permanent residences were within 30 miles of the project. Approximately 68 percent of dock users' total trip spending occurred within 30 miles of the project.

Only new boat purchases within 30 miles of the project are counted in this analysis. Further, it is assumed that slip rental fees (dock maintenance 
fees) and storage fees go primarily to local businesses. However, slip renters and dock owners were not asked to identify the locations of their insurance companies or boat repair shops. Thus, the extent to which these expenditures accrue to the local economy is not known, but they have been counted as occurring locally (within the 16-county region). 


\section{Summary and Discussion}

Marina slip users at Lake Sidney Lanier spent $\$ 33(\$ 40)^{1}$ million in triprelated expenditures and $\$ 31(\$ 38)$ million in purchases of new boats and annual services within 30 miles of the lake in 1999. Combining both triprelated and durable expenditures, the direct economic effects of slip user spending were $\$ 42(\$ 51)$ million in sales, $\$ 13.6$ (\$16.5) million in personal income, \$20 (\$25) million in direct value added, and 472 jobs. With multiplier effects, created by the recirculation of the money spent by slip users, visitor spending generated a total (direct + secondary) of $\$ 67$ (\$81.6) million in local sales, and an associated \$23.6 (\$28.5) million in personal income, $\$ 36$ (\$43.5) million in value added, and 753 jobs. Sectors receiving the greatest benefit from marina slip users were restaurants, retail trade, services, and other manufacturing.

Private dock users spent $\$ 51$ ( $\$ 61$ ) million in trip-related expenditures and \$21 (\$25) million in purchases of new boats and annual services within 30 miles of the lake in 1999. Combining both trip-related and durable expenditures, the direct economic effects of dock user spending were \$45 (\$54) million in sales, \$18 (\$22) million in personal income, \$27 (\$32) million in direct value added, and 749 jobs. With multiplier effects, created by the re-circulation of the money spent by dock users, visitor spending generated a total (direct + secondary) of $\$ 72$ (\$87) million in local sales, and an associated \$29 (\$35) million in personal income, \$44 (\$53) million in value added, and 1,053 jobs. Sectors receiving the greatest benefit from private dock users were restaurants, retail trade, services, and other manufacturing.

The $\$ 42$ million direct sales effect associated with Lake Sidney Lanier Slip user spending is about 1.2 percent of all tourism activity ( $\$ 3.53$ billion) in the 16-county region. Similarly, the 45 million of direct sales effect associated with private dock user spending is about 1.3 percent of the tourism activity ( $\$ 3.53$ billion) of the 16-county region (Sales have been priceinflated for this computation).

${ }^{1}$ Numbers in parentheses are in 2004 dollars (See Table 17). 
Total economic impacts (Tables 15, 16, and 17 (marina); Tables 30, 31, and 32 (private dock)) are useful for accountability purposes, lake support, and explaining the role of the lake in the region's economy. The REAS model results can also be used to evaluate management alternatives and strategies and to conduct sensitivity analyses. The marginal economic impacts of particular visitor segments are useful for evaluating particular actions. Table 39 shows the changes in sales, jobs, income and valued added associated with an increase or decrease of one thousand additional party-trips by marina slip renters at Lake Sidney Lanier. Marginal impact analysis provides answers to the question: "What if?" (reference Foreword).

Table 39. Direct impacts of an additional 1,000 marina slip renter party trips by segment, Lake Sidney Lanier.

\begin{tabular}{|l|r|r|l|r|r|r||}
\hline & $\begin{array}{l}\text { Local } \\
\text { Spending } \\
(\$)\end{array}$ & $\begin{array}{l}\text { Direct Sales } \\
(\$)\end{array}$ & $\begin{array}{l}\text { Personal } \\
\text { Income } \\
(\$)\end{array}$ & $\begin{array}{l}\text { Value } \\
\text { Added } \\
(\$)\end{array}$ & Jobs \\
\hline \hline \multicolumn{7}{|c|}{ (marginal impacts per 1,000 party-trips, in 1999 dollars) } \\
\hline \hline Day use & $\$ 70,371$ & $\$ 41,983$ & $\$ 16,529$ & $\$ 25,127$ & 0.7 \\
\hline Overnight stay & $\$ 241,284$ & $\$ 143,947$ & $\$ 56,673$ & $\$ 86,155$ & 2.4 \\
\hline Small boat & $\$ 94,957$ & $\$ 56,651$ & $\$ 22,304$ & $\$ 33,906$ & 0.9 \\
\hline Medium boat & $\$ 145,867$ & $\$ 87,023$ & $\$ 34,261$ & $\$ 52,084$ & 1.5 \\
\hline Large boat & $\$ 290,835$ & $\$ 173,509$ & $\$ 68,311$ & $\$ 103,848$ & 2.9 \\
\hline \hline & (marginal impacts per 1,000 party-trips, in 2004 dollars) & \\
\hline Day use & $\$ 85,149$ & $\$ 50,799$ & $\$ 20,000$ & $\$ 30,404$ & 0.7 \\
\hline Overnight stay & $\$ 291,954$ & $\$ 174,176$ & $\$ 68,574$ & $\$ 104,247$ & 2.4 \\
\hline Small boat & $\$ 114,898$ & $\$ 68,547$ & $\$ 26,987$ & $\$ 41,027$ & 0.9 \\
\hline Medium boat & $\$ 176,499$ & $\$ 105,297$ & $\$ 41,456$ & $\$ 63,022$ & 1.5 \\
\hline Large boat & $\$ 351,910$ & $\$ 209,946$ & $\$ 82,657$ & $\$ 125,656$ & 2.9 \\
\hline \hline
\end{tabular}

For example, to evaluate the regional economic impacts of adding an additional 29 marina slips, first compute the change in party trips - 10 slips produce 350 party trips (average of 35 trips per slip per year from Table 3). That means 29 slips would produce about 1,000 extra party trips per year. Applying the marginal impacts for the overnight segment in Table 9, the expansion generates an additional $\$ 241,000$ in total trip spending ( $\$ 241$ per party trip from Table 9 times 1,000), $\$ 144,000$ in direct sales in the region, $\$ 57,000$ in personal income, $\$ 86,000$ in value added, and 2.4 jobs in direct effects (computed from ratios in Table 15). In 2004 dollars, the extra 1,000 party trips per year by marina slip users would 
result in $\$ 174,000$ in direct sales in the region and $\$ 68,600$ in direct personal income. ${ }^{1}$ The impact of this alternative could be compared to others.

The economic impacts presented in this report document the economic significance of 198,000 marina slip user trips and 541,000 private dock user trips at Lake Sidney Lanier in 1999. The impacts will vary from year to year with changes in prices, visitor volumes, the mix of visitors attracted, and other changes in the lake and surrounding communities. The REAS model has built-in procedures to price adjust spending averages over time, as we have done in this report. Updated figures may be obtained fairly easily, if there are not significant changes in visitor use and spending patterns. In the absence of significant structural changes in the local economy, multipliers will be quite stable. The primary input for updating the estimates is visitation, which must take into account any changes in the mix of visitors or their length of stay in the area.

In future studies of marina slip renters, it will be critical to do more advance communications with managers and marina operators to obtain more cooperation (e.g., only 4 of 6 marinas at Lanier cooperated in this study) and hence a more representative sample. To be more comprehensive, surveys of yacht club members and off-season slip renters are also desirable.

\footnotetext{
${ }^{1}$ The number of jobs, 2.4, remains the same in 2004 because Table 18 reflects the marginal impacts of 1,000 additional party trips; since the ratio between sales and jobs remains the same between 1999 and 2004, the number of jobs per 1,000 additional party trips does not change.
} 


\section{References}

Chang, W. H., D. B. Propst, D. J. Stynes, and R. S. Jackson. 2003. Recreation visitor spending profiles and economic benefit to Corps of Engineers $(C E)$ projects. ERDC/EL TR-03-21. Vicksburg, MS: U.S. Army Engineer Research and Development Center.

Chang, W. H., D. J. Stynes, R. S. Jackson, and D. B. Propst. 2001. U.S. Army Corps of Engineers Recreation Economic Assessment System (REAS). Portland, OR: Poster presentation at National Natural Resources Management Conference, 2001.

Institute for Water Resources (IWR). 2006. OMB approved surveys. IWR Website. Stuart Davis, Subject Matter Expert, IWR, http://www.waterresources.us/inside/products/pub/surveyssearch.cfm?topic =Recreation (accessed July 10, 2006).

Minnesota IMPLAN Group, Inc. 1996. IMPLAN professional social accounting \$ impact analysis software: User's guide. Stillwater, MN: Minnesota IMPLAN Group, Inc.

Minnesota IMPLAN Group. 2000. IMPLAN professional software, analysis and data guide. 2nd ed., Stillwater, MN: Minnesota IMPLAN Group, Inc.

Propst, D. B., D. J. Stynes, W. H. Chang, and R. S. Jackson. 1998. Estimating the local economic impacts of recreation at Corps of Engineers projects - 1996. Technical Report R-98-1. Vicksburg, MS: U.S. Army Engineer Waterways Experiment Station.

U.S. Army Corps of Engineers. 1999. Project operation-Shoreline management at Civil Works projects. Engineer Regulation 1130-2-406. Washington, DC.

U.S. Army Corps of Engineers. 2006a. Economic impact analysis. Natural Resources Management Gateway, Wen-Huei Chang, Subject Matter Expert, CEERD-EE-E, www.CorpsLakes.us/REAS (accessed July 10, 2006).

U.S. Army Corps of Engineers. 2006b. Lake Sidney Lanier, http://lanier.sam.usace.army.mil/ (accessed July 10, 2006).

U.S. Army Corps of Engineers. 2006c. Natural Resources Management System (NRMS) historical data. Natural Resources Management Gateway, Mike Owen, Subject Matter Expert, CESWF-OD-R. http://CorpsLakes.usace.army.mil/employees/nrms/nrms.html (accessed July 10, 2006).

U.S. Census Bureau. 2006. State and County Quickfacts, http://quickfacts.census.gov/qfd/index.html (accessed April 25, 2006).

U.S. Department of Labor. 2006. Bureau of Labor Statistics, average from 1999-2004, http://stats.bls.gov (accessed April 25, 2006). 


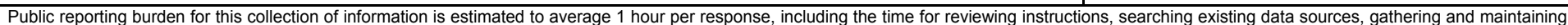

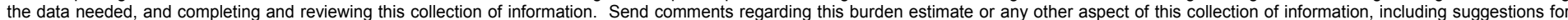

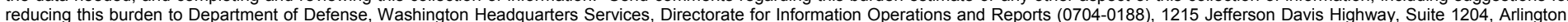

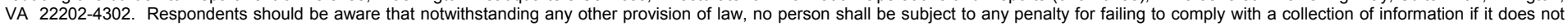
display a currently valid OMB control number. PLEASE DO NOT RETURN YOUR FORM TO THE ABOVE ADDRESS.

\begin{tabular}{l|c}
$\begin{array}{l}\text { 1. REPORT DATE (DD-MM-YYYY) } \\
\text { February 2008 }\end{array}$ & $\begin{array}{c}\text { 2. REPORT TYPE } \\
\text { Final report }\end{array}$ \\
\hline
\end{tabular}

\section{TITLE AND SUBTITLE}

Economic Impacts from Spending by Marina Slip Renters and Private Dock Owners at Lake Sidney Lanier

3. DATES COVERED (From - To)

5a. CONTRACT NUMBER

5b. GRANT NUMBER

5c. PROGRAM ELEMENT NUMBER

5d. PROJECT NUMBER

5e. TASK NUMBER

5f. WORK UNIT NUMBER

8. PERFORMING ORGANIZATION REPORT NUMBER

ERDC/EL TR-08-6

U.S. Army Engineer Research and Development Center, Environmental Laboratory, 3909 Halls Ferry Road, Vicksburg, MS 39180-6199;

Michigan State University, 115 Natural Resources Building, East Lansing, MI 48824

9. SPONSORING / MONITORING AGENCY NAME(S) AND ADDRESS(ES)

10. SPONSOR/MONITOR'S ACRONYM(S)

11. SPONSOR/MONITOR'S REPORT NUMBER(S)

\section{DISTRIBUTION / AVAILABILITY STATEMENT}

Approved for public release; distribution is unlimited.

\section{SUPPLEMENTARY NOTES}

\section{ABSTRACT}

This report documents the local economic impacts of marina slip users and private dock users at Lake Sidney Lanier, located in northern Georgia. This economic assessment is based on the results of a 1999 survey of the samples of Lake Sidney Lanier marina slip renters and private dock owners. Spending estimates are adjusted to 2004 dollars. The economic impacts estimated for Lake Sidney Lanier are useful for accountability purposes, lake support, and explaining the role of the lake in the region's economy. This report demonstrates how the survey results can also be used to evaluate management alternatives and strategies and to conduct sensitivity analyses.

\section{SUBJECT TERMS}

Marina slip renters

Marina slips

16. SECURITY CLASSIFICATION OF:

\section{a. REPORT}

UNCLASSIFIED

b. ABSTRACT
UNCLASSIFIED

Economic assessment Lake Sidney Lanier

c. THIS PAGE

UNCLASSIFIED
Private dock owners

Private docks

\begin{tabular}{|l|c|}
\hline $\begin{array}{l}\text { 17. LIMITATION } \\
\text { OF ABSTRACT }\end{array}$ & $\begin{array}{c}\text { 18. NUMBER } \\
\text { OF PAGES }\end{array}$ \\
& 83 \\
\hline
\end{tabular}

\begin{tabular}{l}
$\begin{array}{l}\text { 19a. NAME OF RESPONSIBLE } \\
\text { PERSON }\end{array}$ \\
\hline $\begin{array}{l}\text { 19b. TELEPHONE NUMBER (include } \\
\text { area code) }\end{array}$
\end{tabular}

Standard Form 298 (Rev. 8-98) Prescribed by ANSI Std. 239.18 